\title{
USO DE SOLUÇÃO CONSERVADORA E DE PELÍCULAS COMESTÍVEIS EM MAÇÃS DA CULTIVAR ROYAL GALA MINIMAMENTE PROCESSADAS: EFEITO NA FISIOLOGIA E NA CONSERVAÇÃO
}

\section{LUCIANA CRISTINA BRIGATTO FONTES}

Dissertação apresentada à Escola Superior de Agricultura "Luiz de Queiroz", Universidade de São Paulo, para obtenção do título de Mestre em Ciências, Área de Concentração: Ciência e Tecnologia de Alimentos.

PIR A CICABA

Estado de São Paulo - Brasil

Junho - 2005 


\section{USO DE SOLUÇÃO CONSERVADORA E DE PELÍCULAS COMESTÍVEIS EM MAÇÃS DA CULTIVAR ROYAL GALA MINIMAMENTE PROCESSADAS: EFEITO NA FISIOLOGIA E NA CONSERVAÇÃO}

\section{LUCIANA CRISTINA BRIGATTO FONTES}

Engenheira Agrônoma

Orientadora: Profa. ${ }^{\text {. }}{ }^{a}$. SILENE BRUDER SIVEIRA SARMENTO

Dissertação apresentada à Escola Superior de Agricultura "Luiz de Queiroz", Universidade de São Paulo, para obtenção do título de Mestre em Ciências, Área de Concentração: Ciência e Tecnologia de Alimentos.

PIRACICABA

Estado de São Paulo - Brasil

Junho - 2005 
Dados Internacionais de Catalogação na Publicação (CIP) DIVISÃO DE BIBLIOTECA E DOCUMENTAÇÃO - ESALQ/USP

Fontes, Luciana Cristina Brigatto

Uso de solução conservadora e de películas comestíveis em maçãs da cultivar

Royal Gala minimamente processadas: efeito na fisiologia e na conservação / Luciana Cristina Brigatto Fontes. - - Piracicaba, 2005.

118 p. : il.

Dissertação (mestrado) - - Escola Superior de Agricultura Luiz de Queiroz, 2005. Bibliografia.

1. Armazenagem de alimentos 2. Conservação de alimentos 3. Fisiologia pós-colheita 4. Maça 5. Microbiologia de alimentos 6. Processamento de alimentos I. Título

CDD 664.80411

"Permitida a cópia total ou parcial deste documento, desde que citada a fonte - O autor" 


\section{$\underline{\mathscr{D E D I C O}}$}

À vó Maria, exemplo de mulher, que nos deixou no transcorrer deste trabalho.

Aos meus pais, Luiz e Cida, por sempre estarem me apoiando, dando tudo de si, além de muito amor e carinho, pois não seria nada e não estaria onde estou sem a presença, esforço e compreensão deles.

Ao meu irmão, Rodrigo, pelo carinho, bondade e apoio na aquisição dos frutos para a realização deste trabalho.

À minha cunhada, Daniela, pela atenção e disposição em auxiliar-me sempre que necessitei, especialmente nas traduções.

Aos meus primos, Edinho, Alessandra e Isabela, que sempre me proporcionam momentos de alegria e pelo apoio durante este trabalho.

Ao meu namorado, Rafael, que mesmo longe sempre esteve disposto a ajudar-me com paciência e compreensão nos momentos que encontrei dificuldades. 


\section{AGRADECIMENTOS}

A Deus, pelo dom da vida, sabedoria e por sempre iluminar meu caminho.

À todos aqueles aos quais dediquei este trabalho, pelo constante incentivo, carinho e compreensão.

À Escola Superior de Agricultura "Luiz de Queiroz" (ESALQ/USP) em especial ao Departamento de Agroindústria, Alimentos e Sutrição, pela oportunidade da realização deste trabalho.

À minha orientadora, Profa $\mathcal{D r}^{a}$ Silene Bruder Silveira Sarmento, pelos ensinamentos, apoio, orientação criteriosa e sugestões pertinentes.

À Profa Dra Marta Helena Fillet Spoto, pelo apoio nas análises sensoriais e sugestões na qualificação.

À Profa $\operatorname{Dr}^{a}$ Celina Maria Henrique pela simpatia e sugestões na qualificação.

Ao Prof. Dr. Ernani Porto, pelo apoio nas análises microbiológicas.

Ao Prof. Dr. Ângelo Jacomino, pelo auxílio nas análises fisiológicas e sugestões na qualificação.

Ao Prof. Dr. Tadeu, pelo apoio e incentivo nas análises estatísticas.

Ao Prof. Dr. Marchini, pelo empréstimo dos tubos utilizados nas análises microbiológicas.

À Carlota, pela amizade, apoio e incentivo durante todas as análises realizadas neste trabalho.

À Clarice Matraia, pelo apoio na avaliação das cores.

À COOPERSERRA, pela doação dos frutos utilizados nos experimentos.

À Coordenadoria de Aperfeiçoamento do Pessoal de Ensino Superior (CAPES) pela concessão da bolsa de estudo. 
Ao Núcleo de Apoio à Pesquisa/Microscopia Eletrônica Aplicada à Pesquisa Agropecuária (NAP/MEPA-ESALQ/USP) pela disponibilização do uso do microscópio eletrônico de varredura.

Ao Luiz Carlos Rodrigues e Rubens César Pereira, pela amizade e auxílio nas fotos.

À Féxô e toda sua família pela amizade sincera, pelo carinho e atenção em todos momentos que precisei.

Às amigas: Fivela, Bék e Anna Julia, pelos momentos de alegria, apoio e por sempre estarem dispostas a ajudar-me.

Às amigas de departamento: Juliana Galvão, Vanessa Pires, Cristiane Cassiolato, Ana Carolina Leme e Manoel pelo companheirismo e pela força.

Á amiga de departamento Roberta Rizzo pelos momentos de alegria e pelo auxílio na formatação deste trabalho.

A todos os participantes das análises sensoriais.

As Gibliotecárias Beatriz Giongo e Midian Gustinelli, pelo apoio e atenção.

As secretárias de pós-graduação: Regina e Gislaine Nóbilo pelo auxílio e paciência.

À Regina Marafon, Márcia Bertarelli e Sidnei Sbizaro pela atenção e apoio sempre que precisei.

Aे academia Betty Training pelos professores atenciosos e pelos momentos de descontração.

E a todos aqueles que, direta ou indiretamente colaboraram na realização $e$ desenvolvimento deste, que outrora deixei de citar. 


\section{SUMÁRIO}

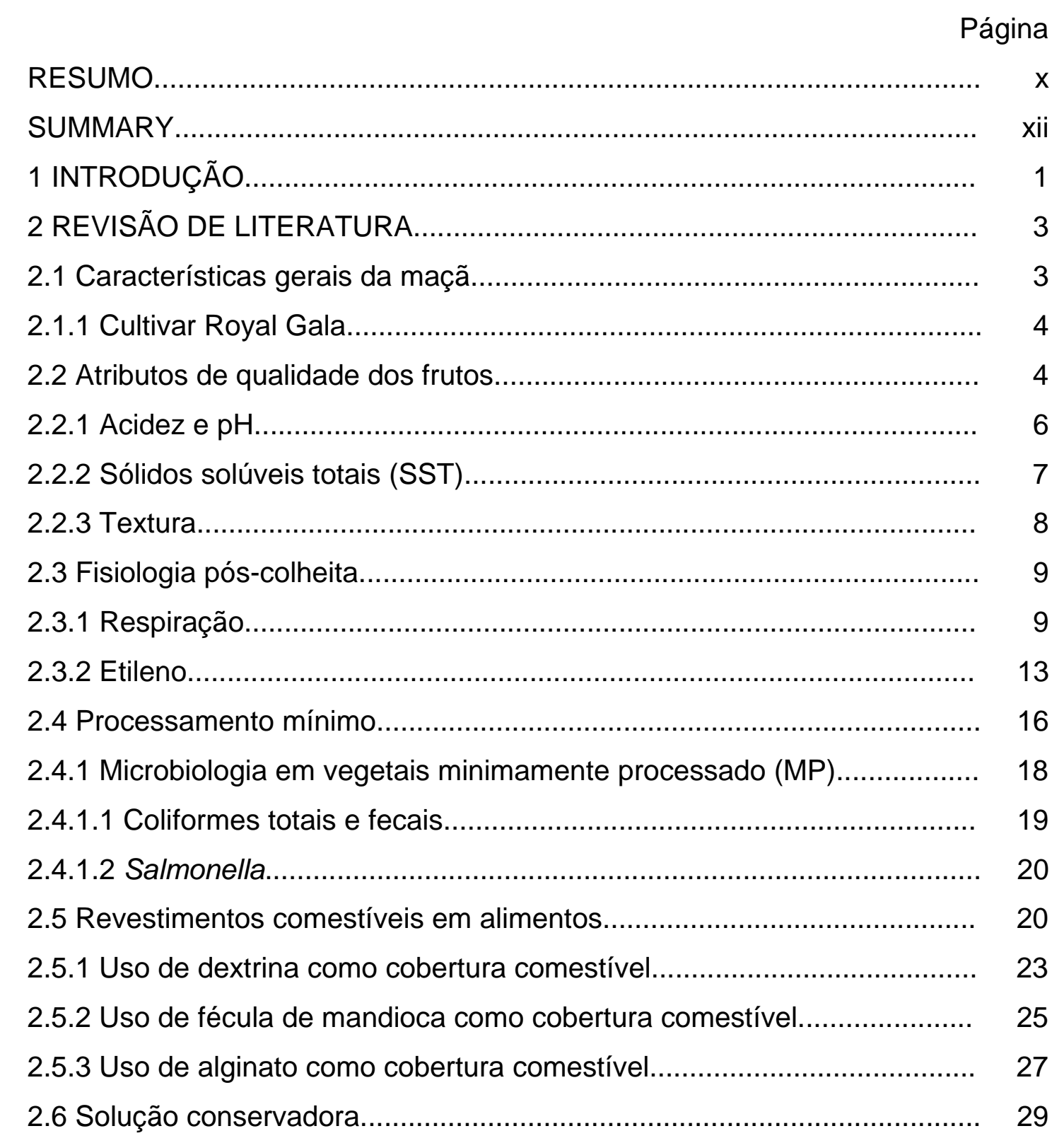




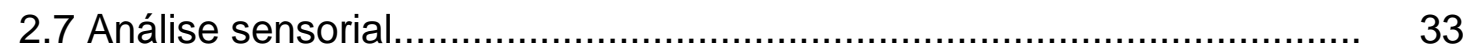

3 MATERIAL E MÉTODOS ....................................................... 35

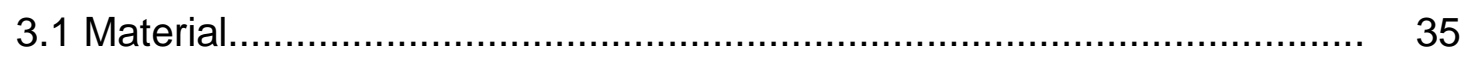

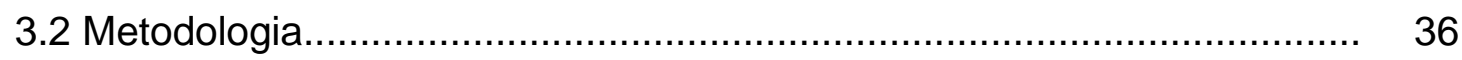

3.2.1 Processamento das maçãs........................................................ 36

3.2.2 Aspecto superficial das maçãs MP............................................. 39

3.2.3 Análises fisiológicas................................................................ 39

3.2.3.1 Taxa respiratória................................................................ 39

3.2.3.2 Produção de etileno....................................................... 40

3.2.4 Análises físicas e físico-químicas.............................................. 40

3.2.4.1 Umidade......................................................................... 40

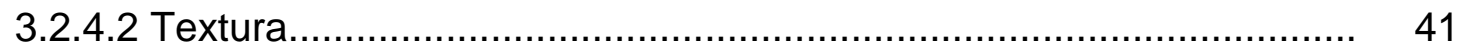

3.2.4.3 Teor de sólidos solúveis...................................................... 41

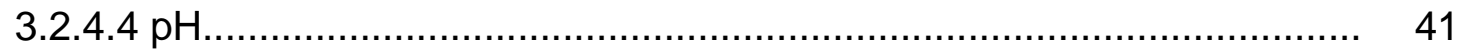

3.2.4.5 Acidez total titulável.......................................................... 41

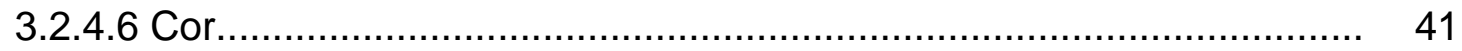

3.2.5 Análises microbiológicas.......................................................... 42

3.2.5.1 Preparo da amostra............................................................ 42

3.2.5.2 Contagem de coliformes totais e fecais..................................... 42

3.2.5.3 Salmonella....................................................................... 43

3.2.6 Análise sensorial................................................................ 44

3.2.7 Análise estatística.................................................................. 53

4 RESULTADOS E DISCUSSÃO ...................................................... 54

4.1 Aspecto geral das maçãs MP.................................................... 54

4.2 Aspecto superficial das maçãs................................................... 57

4.3 Fisiologia................................................................................ 59

4.3.1 Taxa respiratória................................................................. 59

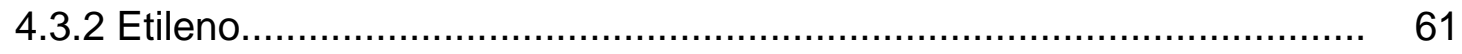

4.4 Físicas e físico-químicas das maçãs MP............................................ 63

4.4.1 Umidade......................................................................................... 63 


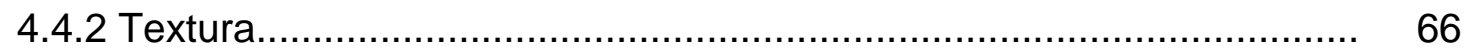

4.4.3 Teor de sólidos solúveis totais................................................... 68

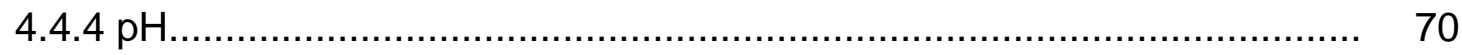

4.4.5 Acidez total titulável............................................................... 71

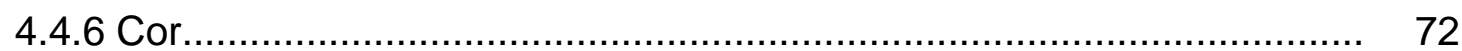

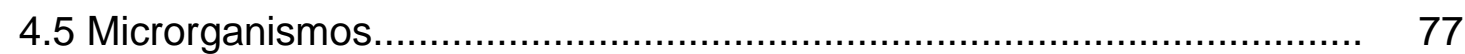

4.6 Análise sensorial......................................................................... 77

4.6.1 Aparência........................................................................... 78

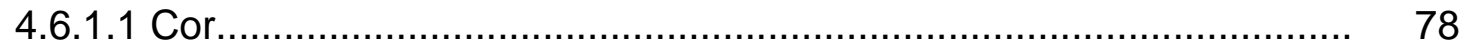

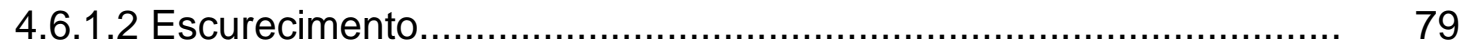

4.6.1.3 Uniformidade de cor......................................................... 80

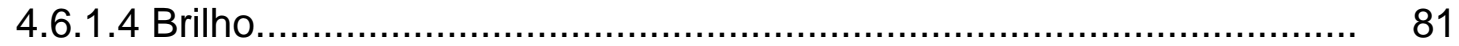

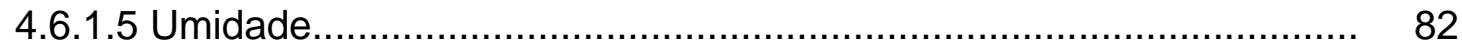

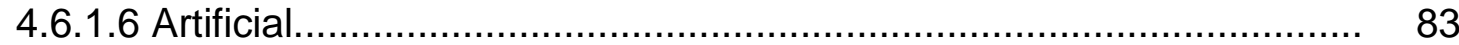

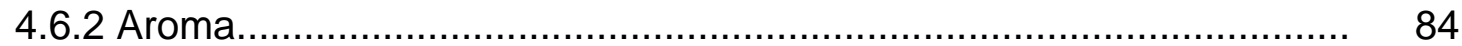

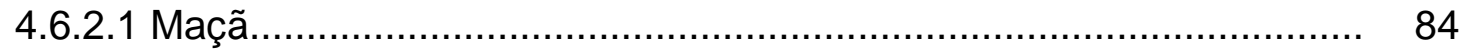

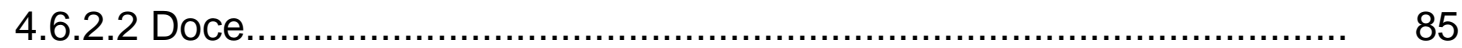

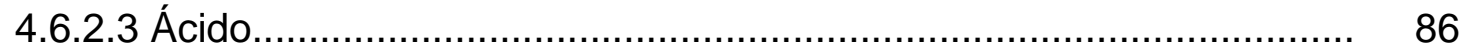

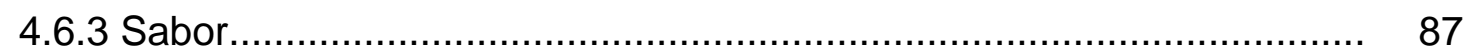

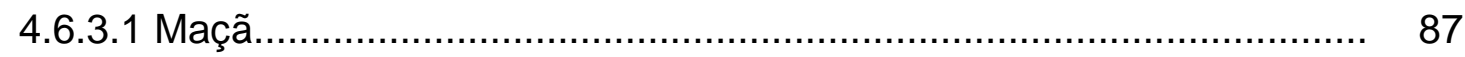

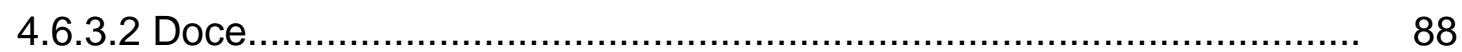

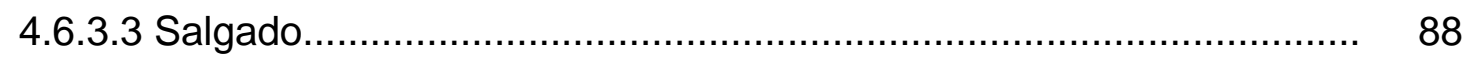

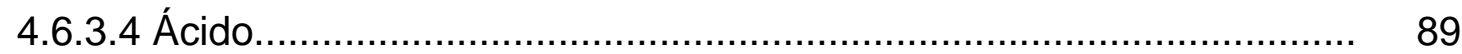

4.6.3.5 Fresca........................................................................ 90

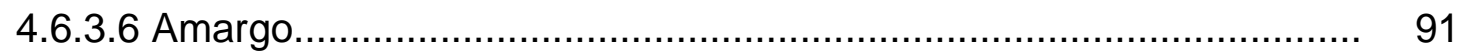

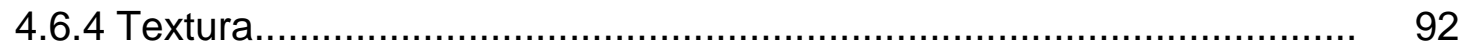

4.6.4.1 Característica de maçã.............................................................. 92

4.6.4.2 Maciez .......................................................................... 93

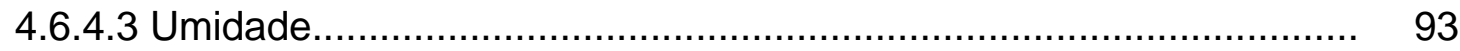

5 CONSIDERAÇÕES FINAIS ...................................................... 95 
6 CONCLUSÃO...

98

7 REFERÊNCIAS BIBLIOGRÁFICAS................................................. 101 


\title{
USO DE SOLUÇÃO CONSERVADORA E DE PELÍCULAS COMESTÍVEIS EM MAÇÃS DA CULTIVAR ROYAL GALA MINIMAMENTE PROCESSADAS: EFEITO NA FISIOLOGIA E NA CONSERVAÇÃO
}

\author{
Autora: LUCIANA CRISTINA BRIGATTO FONTES \\ Orientadora: Prof ${ }^{a}$ Dra: SILENE BRUDER SILVEIRA SARMENTO
}

\section{RESUMO}

Uma das propostas atuais para aumentar a vida útil de frutas minimamente processadas (MP) é a busca de um material que seja aderente às superfícies cortadas do fruto para minimizar deteriorações fisiológicas, físicoquímicas e microbianas. O objetivo do presente trabalho foi avaliar o efeito de solução conservadora e películas comestíveis na conservação de maçãs da cultivar Royal Gala MP durante armazenamento refrigerado. Os tratamentos foram o controle, a solução conservadora (1\% ácido ascórbico; 0,5\% ácido cítrico; $0,7 \% \mathrm{NaCl} ; 0,25 \% \mathrm{CaCl}_{2}$ ) e as soluções filmogênicas em associação com a solução conservadora. Foram testadas a dextrina (5,5\%), a fécula de mandioca (3\%) e o alginato de sódio (2\%) com $\mathrm{CaCl}_{2}(0,6 \%)$. A qualidade das maçãs MP foi monitorada por análises fisiológicas, físicas, físico-químicas, microbiológicas e sensoriais até o $13^{\circ}$ dia de armazenamento. A solução conservadora reduziu a taxa respiratória e a produção de etileno em relação ao controle e promoveu maior claridade da polpa. A firmeza dessas maçãs 
aumentou com o tempo de armazenamento. Os tratamentos com películas apresentaram redução média de $38 \%$ na taxa respiratória e mais de $50 \%$ na produção de etileno em relação ao controle, sendo o alginato o mais eficiente. A película de alginato vista em microscópio eletrônico de varredura, destacou-se das demais (dextrina e fécula de mandioca) pela homogeneidade e ausência de poros, fato que contribuiu para sua eficiência no controle da taxa respiratória e da produção de etileno. As maçãs MP recobertas com alginato apresentaram melhor retenção de umidade no início do armazenamento, entretanto, houve perda significativa de umidade pelas maçãs durante o armazenamento. A maior concentração de sólidos solúveis foi verificada em maçãs controle, com solução conservadora e com alginato. Maçãs com alginato apresentaram menor acidez e coloração mais escura dentre os tratamentos, respectivamente, em função do pH e da coloração da própria solução filmogênica. Nas maçãs controle os valores de firmeza dos tecidos diminuíram com o armazenamento e nos demais tratamentos, a tendência foi oposta. As coberturas de dextrina e fécula de mandioca tenderam a exercer influência semelhante nas características físicas e físico-químicas das maçãs, apresentando valores intermediários entre os tratamentos com solução conservadora e com alginato. Na maçã inteira (antes do processamento) foi detectada ausência de Salmonella. Quer nas maçãs MP tratadas com película ou sem película, não foram detectados coliformes totais e fecais durante todo o armazenamento. No tratamento que utilizou apenas solução conservadora as maçãs MP apresentaram notas mais próximas do natural (maçãs recém-cortadas) pela análise sensorial descritiva quantitativa, tendo com isso melhor aceitação em relação aos parâmetros de aparência, aroma, sabor e textura. Os tratamentos com película apresentaram boa aceitação pelos provadores, exceto as maçãs MP com alginato, que proporcionaram certa estranheza devido ao brilho da película. O produto foi classificado como de aparência artificial e seu sabor como sendo de "fruta passada". 


\title{
USE OF CONSERVATIVE SOLUTION AND EDIBLE COATING IN MINIMALLY PROCESSED ROYAL GALA CULTIVAR APPLE: EFFECT IN PHYSIOLOGY AND IN THE CONSERVATION
}

\author{
Author: LUCIANA CRISTINA BRIGATTO FONTES \\ Adviser: Prof ${ }^{\mathrm{a}}$ Dr $^{\mathrm{a}}$ SILENE BRUDER SILVEIRA SARMENTO
}

\section{SUMMARY}

One of the current proposals to increase the shelf life of the minimally processed (MP) fruits is the investigation of a material that is adherent to the cut surface of the fruit in order to minimize physiological, physico-chemical and microbial deteriorations. The goal of the study is to evaluate the effect of preservative solution and edible coatings in the conservation of the MP apples of Royal Gala cultivar during the refrigerated storage. The treatments are control, the preservative solution ( $1 \%$ of ascorbic acid; $0.5 \%$ of citric acid; $0.7 \%$ of $\mathrm{NaCl}$; $0.25 \%$ of $\mathrm{CaCl}_{2}$ ) and the filmogenic solution associated with the preservative one. It was tested the dextrin (5.5\%), cassava starch (3\%) and sodium alginate (2\%) with $\mathrm{CaCl}_{2}$ (0.6\%). The quality of the MP apples was monitored by physiological, physical, physico-chemical, microbiological and sensorial analysis until the $13^{\text {th }}$ day of storage. The preservative solution decreased the respiratory rate and the ethylene production compared to the control and, promoted a lighter pulp. The firmness of these apples increased with the time of storage. 
The treatment with coatings showed an average decrease of $38 \%$ in the respiratory rate and more than $50 \%$ in ethylene production compared to the control, being the alginate based the most efficient. The alginate coating, seen from a scanning electron microscope, detaches from the others (dextrin and cassava starch) because of its homogeneities and absence of pores, fact that contributed to its efficiency in controlling the respiratory rate and ethylene production. The MP apples with alginate coating presented a better retention of moisture in the beginning of storage, however, there was significant loss of moisture content with the storage time. The higher soluble solids concentrations were verified in the apples of control, with conservative solution and with alginate. Apples with alginate presented less acidity and a darker coloration among the treatments because of the $\mathrm{pH}$ and the coloration of the filmogenic solution itself. In the apples in control, the firmness of the tissue decreased during storage and in the other treatments, the tendency was the opposite. The cover of dextrin and cassava starch tended to likely influence the physical and physico-chemical characteristics of the apples, showing intermediated values compared to preservative solution and alginate treatments. In the whole fruit (before the processing), it was detected absence of Salmonella. As well as in the MP apples treated with or without coatings, it was detected no total and fecal coliforms during storage. In the treatment that used only the preservative solution, the MP apples presented grades very close to natural (apples just cutted) by the quantitative descriptive sensorial analyses, thus having the best acceptation related to the appearance, smell, taste and texture. The treatments with coatings presented a good acceptation from the tasters, except the MP apples with alginate that appear a little strange due the coating bright. The product was classified as artificial in appearance and deteriorated-fruit in taste. 


\section{INTRODUÇÃO}

O hábito alimentar do brasileiro tem apresentado mudanças consideráveis nas últimas décadas. Tais mudanças decorreram da participação efetiva da mulher no mercado de trabalho, proporcionando pouca disponibilidade de tempo para o preparo de alimentos e ao avanço do uso de novas tecnologias na indústria alimentícia, possibilitando melhoria e manutenção da qualidade dos alimentos, além de conveniência e rapidez no preparo.

Tendência crescente na atualidade são os alimentos minimamente processados (MP), ou seja, qualquer fruta ou hortaliça, que passa pelas operações de seleção, lavagem, descascamento e corte visando obter um produto fresco e conveniente.

Os alimentos MP apresentam vida útil inferior à das frutas e hortaliças inteiras, devido às deteriorações fisiológicas, físico-químicas e microbianas dos tecidos expostos pelo corte. O processamento e o armazenamento podem causar problemas como a condensação de vapor d'água no interior da embalagem, com conseqüente perda da transparência do filme que recobre as bandejas, a liberação e acúmulo de etileno pelos vegetais dentro do envoltório fechado e também ocorre perda de umidade superficial e do fruto em si, que se torna esbranquiçado. Para alguns vegetais, acontece ainda o escurecimento oxidativo. A contaminação microbiana pode ocorrer devido à exsudação de líquidos do produto MP e a exposição de uma maior superfície de contato do próprio fruto.

Uma forma de aumentar a vida útil de frutas MP seria a busca de um material que seja aderente às superfícies cortadas do fruto, ou seja, a utilização 
de revestimentos ou coberturas comestíveis que, quando aplicados à superfície do produto minimizam os problemas apontados anteriormente.

Assim, o objetivo do presente trabalho foi avaliar o efeito do uso de solução conservadora e películas à base de dextrina, fécula de mandioca e alginato de sódio na fisiologia e na conservação de maçãs "Royal Gala" MP durante armazenamento refrigerado. 


\section{REVISÃO DE LITERATURA}

\subsection{Características gerais da maçã}

A macieira (Malus domestica, Borkh.), pertencente à família Rosaceae, é originária da Europa e da Ásia. A exploração comercial no Brasil foi iniciada na década de 60, em Santa Catarina, e em poucos anos a maçã se transformou em produto de intensa comercialização no país, sendo que, das fruteiras de clima temperado, a macieira foi a que mais se desenvolveu nos últimos anos. Os Estados de Santa Catarina e Rio Grande do Sul são os principais produtores nacionais, sendo responsáveis por aproximadamente 90\% da produção (Empresa de Pesquisa Agropecuária e Extensão Rural de Santa Catarina Epagri, 2002).

O consumo de maçãs no Brasil foi sustentado, durante muito tempo, pelas importações, especialmente da Argentina. Em meados da década de 60, o Brasil era o $4^{\circ}$ importador de maçãs no mundo e o consumo nacional per capita não passava de $2 \mathrm{~kg} / \mathrm{ano}$. No ano de 2002, entretanto, o Brasil exportou maçãs para a Europa e América do Norte. A produtividade média foi de 23t/ha, no entanto alguns pomares produziram 60t/ha, e o consumo per capita foi de aproximadamente 5kg/ano (Epagri, 2002).

O pico de oferta de maçãs ocorre durante os meses de fevereiro a maio, onde os preços recebidos pelos produtores são historicamente mais baixos. Normalmente, é necessário armazenar cerca de $60 \%$ da safra, dependendo do ano (Epagri, 2002).

As maçãs podem ser conservadas por até três meses em câmara fria convencional, perdendo o sabor e a textura quando mantidos além deste 
período. Em atmosfera controlada podem ser conservados por até cinco meses, sem perder suas características iniciais (Epagri, 2002).

A industrialização da maçã no Brasil ainda é restrita devido basicamente à falta de matéria-prima. A produção nacional de 2003 foi de aproximadamente 829 mil toneladas e $85 \%$ desta produção foi destinada ao consumo in natura, mesmo aquelas com qualidade inferior. Os $15 \%$ restantes da produção foram encaminhados principalmente para a produção de suco concentrado (FNP, 2004).

\subsubsection{Cultivar Royal Gala}

A cultivar Royal Gala é uma mutação espontânea da cultivar Gala, descoberta em 1971 por Hove em pomar de sua propriedade, em Matamata, Nova Zelândia, e introduzida comercialmente no Brasil em 1974 (Epagri, 2002).

Os frutos são atrativos, apresentando epiderme vermelho-rajada sobre fundo amarelo, lisa e brilhante. $\mathrm{O}$ tamanho varia de pequeno a médio, tendendo mais ao pequeno quando o raleio não é adequado. O formato é redondo-cônico, sendo a polpa de coloração amarelo-creme, firme, crocante, suculenta, bem balanceada em ácidos e sólidos solúveis. A maturação ocorre entre o final da segunda quinzena de janeiro e a segunda quinzena de fevereiro, sendo mais precoce nas regiões mais quentes (Epagri, 2002). Esta cultivar enquadra-se dentro das exigências dos consumidores brasileiros, que preferem frutos de sabor adocicado e epiderme vermelha (Lima, 1999).

\subsection{Atributos de qualidade dos frutos}

Os atributos de qualidade dos frutos de maneira geral estão na dependência de suas características físicas e químicas e são peculiares a cada espécie e cultivar, variando também com o clima, solo, tratos culturais e época de maturação (Chitarra, 1998).

As mudanças físicas e químicas que ocorrem durante a maturação dos frutos estão associadas às mudanças na textura, aparência, sabor e aroma 
resultando em alta qualidade degustativa (Epagri, 2002). De acordo com Blanke (1991) tais transformações ocorrem em nível celular, envolvendo processos de degradação e síntese de compostos orgânicos, além de alterações na atividade enzimática. O conhecimento destas mudanças metabólicas associadas com a maturação é essencial para prolongar a conservação da qualidade dos frutos e prevenir os distúrbios fisiológicos.

O aumento relativamente rápido da taxa respiratória (climatérico) e o aumento da síntese de etileno são as principais alterações fisiológicas que ocorrem durante a maturação de maçãs. Muitas das mudanças físicas, químicas e fisiológicas, tais como alteração da composição de pigmentos (mudança da cor da epiderme), mudanças estruturais dos polissacarídeos do córtex (redução da firmeza da polpa), alterações da produção e conteúdo de açúcares, ácidos, ésteres (mudança no sabor dos frutos), acúmulo de ceras sobre a epiderme (mudança da aparência) e desenvolvimento da camada de abscisão na base do pedúnculo (abcisão dos frutos), são aceleradas após o climatérico e aumento da produção de etileno (Epagri, 2002).

As características físicas, como a massa, comprimento, textura, diâmetro transversal e coloração da epiderme influenciam na aceitabilidade dos frutos pelo consumidor e no rendimento industrial, enquanto que as características físico-químicas, reveladas pelos teores de sólidos solúveis totais (SST), acidez total titulável (ATT) e balanço SST/ATT, são indicadoras das características organolépticas, importantes tanto na industrialização, quanto no consumo dos frutos in natura (Alvarenga \& Fortes, 1985).

Parâmetros como acidez e sólidos solúveis são muito importantes na avaliação da qualidade de maçãs, tanto sensorial, considerando o consumo, quanto comercialmente, na estocagem da fruta. Outro fator importante para a caracterização da maçã é o pH, visto que há uma variação entre 3,2 e 3,8, neste parâmetro para diferentes cultivares (La Belle, 1981). 


\subsubsection{Acidez e pH}

A acidez de um fruto é dada pela presença dos ácidos orgânicos, que servem de substrato para a respiração. Porém, muitos dos ácidos são voláteis e por isso compõem o aroma característico dos frutos. Os ácidos são encontrados nos vacúolos das células, sob a forma livre ou combinada com sais, ésteres e glicosídios (Chitarra \& Chitarra, 1990).

Segundo Kramer (1973) os dois métodos mais comumente utilizados para medir a acidez de frutos são a acidez total titulável (ATT) e o potencial hidrogeniônico $(\mathrm{pH})$, sendo que o primeiro representa todos os grupamentos ácidos encontrados (ácidos orgânicos livres e na forma de sais e compostos fenólicos), enquanto o segundo determina a concentração hidrogeniônica da solução.

Maçãs apresentam elevada acidez se comparada a outras frutas. O conteúdo de ácidos orgânicos diminui gradualmente durante a maturação e armazenagem dos frutos. As variações da acidez total titulável durante a maturação dos frutos na planta são muito pequenas, por isto este parâmetro é menos consistente para estimar o estádio de maturação e o ponto de colheita. No entanto, se a acidez titulável for baixa na colheita, a qualidade organoléptica após a armazenagem pode ser inaceitável pelos consumidores (Epagri, 2002).

Assim, um nível mínimo de acidez na colheita, abaixo do qual os frutos não devem ser destinados à armazenagem, pode ser definido para cada cultivar (Bartram,1993). A acidez total titulável é um dos mais importantes parâmetros de qualidade de maçãs após armazenagem. Considerando que o ácido málico é o ácido predominante no suco de maçãs (Wills et al., 1981), a acidez pode ser expressa como equivalente de ácido málico.

Durante o amadurecimento de frutas, o teor de ácidos orgânicos tende a diminuir, devido à oxidação dos mesmos no ciclo dos ácidos tricarboxílicos, em decorrência do processo respiratório ou da conservação de açúcares, pois nesta fase ocorre maior demanda energética pelo aumento do metabolismo (Chitarra \& Chitarra, 1990). 
A reação enzimática envolvida no escurecimento dos tecidos depende do $\mathrm{pH}$. Uma redução de 0,5 no pH natural de maçãs resultou no decréscimo de $50 \%$ da atividade da polifenoloxidase. As modificações bioquímicas do aroma e sabor são decorrentes das peroxidações enzimáticas catalizadas por lipoxigenases, levando a formação de aldeídos e cetonas (Hildebrand, 1989).

\subsubsection{Sólidos solúveis totais (SST)}

Os SST geralmente aumentam com o transcorrer do processo de maturação dos frutos, seja pela biossíntese, degradação de polissacarídeos ou perda de água dos frutos, resultando em maior concentração dos mesmos. A perda varia com a taxa de respiração, já que os sólidos são substratos utilizados no processo respiratório (Lidster et al., 1980).

Aproximadamente $99 \%$ dos sólidos solúveis do suco de maçãs correspondem aos açúcares solúveis e o restante a ácidos orgânicos, sais inorgânicos e outras moléculas (Little, 1992). Os açúcares solúveis mais abundantes no suco de maçãs são frutose, glucose e sacarose e, em menor proporção, o sorbitol. Os açúcares solúveis resultantes da degradação do amido, bem como o ácido málico, são consumidos como substrato do metabolismo respiratório. Embora o conteúdo de açúcares solúveis seja maior que o conteúdo de ácido málico, a taxa de consumo de ácido málico durante a maturação é superior à dos açúcares. Esse fato resulta em aumento da relação açúcar/ácido e mudanças do sabor dos frutos (Epagri, 2002).

No período correspondente à maturação comercial, os teores de SST têm sido de 11,2 a $12,4^{\circ}$ Brix para a cv. Gala, de 12,3 a 13,5ºrix para a cv. Golden Delicious e de 13 a 14,4B Brix para a cv. Fuji (Argenta et al., 1995). Em anos ou regiões caracterizadas por baixo acúmulo de horas de sol durante o desenvolvimento dos frutos e ou pelo excesso de chuvas e alta umidade relativa, os frutos apresentam menores teores de SST (Epagri, 2002). 


\subsubsection{Textura}

O termo textura tem sido confundido, muitas vezes, com firmeza. A firmeza da polpa refere-se ao grau de dureza da fruta, enquanto que a textura é mais complexa e de difícil determinação, uma vez que reflete a sensação produzida nos lábios, língua, mucosa da boca, dentes e ouvidos. Essas sensações são representadas pela dureza, maciez, fibrosidade, suculência, granulosidade, qualidade farinácea, resistência e elasticidade (Kluge, 2002).

A textura sofre modificações consideráveis durante o amadurecimento e conservação das frutas, sendo o amaciamento ou amolecimento dos tecidos a alteração mais marcante. O amolecimento de uma fruta pode ser resultante de três processos: perda excessiva de água dos tecidos, com diminuição da pressão de turgescência, o que ocorre em situações de armazenamento em baixa umidade relativa do ar; quebra do amido; ou modificações observadas na lamela média e parede celular, principalmente devido à atividade enzimática (Kluge, 2002).

A firmeza é um fator crítico que pode influenciar o período de conservação e a resistência ao manuseio, ao transporte e ao ataque de microrganismos (Carvalho, 1994).

A pectina, que corresponde a uma cadeia do ácido poligalacturônico com grau variável de esterificação e metilação, juntamente com a celulose, a hemicelulose e o cálcio, forma o material estrutural das paredes celulares dos vegetais, estando presente em maior quantidade na lamela média. A combinação destes compostos forma a protopectina, que é insolúvel em água. Durante o crescimento da fruta, a protopectina mantém uma forte coesão das células e, por conseqüência, a fruta apresenta-se extremamente firme antes da sua maturação. No transcorrer da maturação, após a fruta atingir o tamanho máximo, o cálcio é desprendido da protopectina pela ação da enzima protopectinase, iniciando a solubilização da pectina. Outras duas enzimaschave atuam na modificação da textura: a poligalacturonase (PG) e a pectinametilesterase (PME). A PG atua na despolimerização ou encurtamento 
da cadeia do ácido poligalacturônico, enquanto que a PME promove a desesterificação ou remoção dos grupos metílicos ou acetil da cadeia. Com a atividade destas enzimas, a pectina passa da forma insolúvel para a forma solúvel, observando-se um marcante amaciamento da polpa das frutas (Kluge, 2002).

De acordo com Varoquaux et al. (1990) fatias de kiwi MP armazenados a $2^{\circ} \mathrm{C}$ perderam $50 \%$ da firmeza inicial em um período menor que 2 dias. Os autores relatam que a perda da firmeza dos tecidos de fatias de kiwi MP ocorre possivelmente em decorrência da hidrólise de componentes da parede celular por enzimas pectinolíticas liberadas pelas células danificadas e que se difundem pelos tecidos mais internos.

Em maçãs não tem sido observada degradação da celulose durante a maturação. Assim, a redução da firmeza da polpa de maçãs tem sido atribuída, principalmente, às atividades da poligalaturonase (PG), $\beta$-galactosidase e pectinesterase que degradam os polissacarídeos pécticos da parede celular e da lamela média (Epagri, 2002).

Treptow et al. (1990), trabalhando com maçãs da cultivar Gala conservadas sob refrigeração, observaram um aumento significativo no enrugamento da casca, com o tempo de armazenamento, o que demonstrou haver perda de umidade da fruta. Este fenômeno resulta na redução da suculência da matéria-prima.

\subsection{Fisiologia pós-colheita}

\subsubsection{Respiração}

Após a colheita, a respiração do fruto torna-se o principal processo fisiológico, pois o mesmo não depende mais da absorção de água e minerais efetuadas pelas raízes, da translocação de nutrientes pelo sistema vascular, nem da atividade fotossintética da planta-mãe, e sim de suas próprias reservas 
de substratos, acumulados durante o seu crescimento (Chitarra \& Chitarra, 1990).

A respiração consiste na decomposição oxidativa de substâncias complexas presentes nas células, como o amido, açúcares e ácidos orgânicos em moléculas simples, $\mathrm{CO}_{2}$ e $\mathrm{H}_{2} \mathrm{O}$, com produção de energia (calor e ATP) (Kluge, 2002).

A respiração pode ocorrer na presença ou ausência de $\mathrm{O}_{2}$ (respiração anaeróbica, também chamada de fermentação). Nesse caso, a liberação de energia será reduzida e a produção de álcoois e aldeídos afetará negativamente a qualidade do fruto (Kader, 1995).

Um fator determinante na longevidade da fruta após a colheita é o tipo ou padrão respiratório. Em função do padrão respiratório, as frutas podem ser classificadas em climatéricas e não climatéricas. Nos frutos climatéricos, como é o caso da maçã, a atividade metabólica aumenta grandemente, causando transformações físicas e bioquímicas nos frutos. Este processo é iniciado pela síntese endógena de etileno, que é aparentemente autocatalítica, e que, por sua vez, estimula a respiração e os demais processos metabólicos, como o amaciamento da polpa, degradação da clorofila, redução da acidez, degradação do amido, aumento de açúcares e desaparecimento de taninos, responsáveis pela adstringência (Brandy,1987; Yang, 1987).

A taxa de respiração depende tanto de fatores internos quanto de fatores externos. Entre os fatores internos estão: a espécie, a cultivar e o estádio de desenvolvimento. Entre os fatores externos estão a temperatura, a composição atmosférica (concentrações de $\mathrm{CO}_{2}, \mathrm{O}_{2}$ e etileno) e os estresses (Kluge, 2002).

De acordo com Ahvenainen (1996), a atividade respiratória de produtos minimamente processados aumenta 1,2 a 7,0 vezes ou até mais, dependendo do produto, grau de corte e temperatura. Caso as condições de embalagem forem anaeróbicas, poderá ocorrer fermentação e, portanto, a formação de etanol, aldeídos e cetonas. 
A temperatura, juntamente com as concentrações de $\mathrm{O}_{2}$ e $\mathrm{CO}_{2}$, são os maiores determinantes da respiração. Com o manejo adequado da temperatura e da atmosfera de armazenamento, é possível reduzir a respiração a um nível mínimo sem causar injúrias ao produto. Quando se verifica uma temperatura elevada na conservação, observa-se que a respiração se eleva, aumentando o consumo de nutrientes. Com esse consumo, o fruto torna-se flácido e mais propício a se tornar farináceo (Awad, 1993).

De maneira geral, a taxa de deterioração de um produto colhido é proporcional à sua taxa respiratória. A temperatura a qual a fruta é exposta influencia diretamente na respiração, sendo que o aumento de $10^{\circ} \mathrm{C}$ na temperatura do produto eleva em 2 a 3 vezes a sua taxa respiratória e, conseqüentemente, diminui a sua vida pós-colheita (Kluge, 2002).

O efeito do descascamento, do corte e de outras injúrias, provocadas durante as etapas do processamento mínimo, têm como conseqüência o rompimento de organelas, a modificação da permeabilidade da célula, a desorganização celular, a ativação da síntese do etileno e o aumento na respiração (Chitarra, 1998).

Os produtos minimamente processados são mais perecíveis que tecidos intactos. Portanto, tratamentos que reduzam a respiração são importantes para aumento na vida útil destes produtos. Kato-Noguchi \& Watada (1997) observaram que a taxa respiratória de cenouras minimamente processadas foi substancialmente reduzida com a aplicação do ácido cítrico. O ácido cítrico está envolvido na inibição da enzima fosfofrutoquinase, que catalisa a fosforilação da frutose 6-fosfato em 1,6-bifosfato na via glicolítica do metabolismo respiratório.

A atmosfera controlada inibiu atividade da polifenoloxidase em cubos de maçãs minimamente processadas (Rocha \& Morais, 2001). Os autores verificaram que quanto mais elevada a concentração de $\mathrm{CO}_{2}$, maior a capacidade de inibição da PFO. Segundo Nicoli et al. (1994) o escurecimento 
enzimático em maçãs "Golden Delicious" pode ser inibido, com sucesso, pela aplicação de embalagens com atmosfera modificada.

Gil et al. (1998) relataram que em maçãs da variedade Fuji minimamente processadas, o uso de atmosfera livre de oxigênio associado ao uso de tratamento com imersão em ácido ascórbico foi efetivo no controle do escurecimento enzimático. Os mesmos autores não recomendam o uso isolado da atmosfera livre de oxigênio em função de seu efeito sobre as características organolépticas e segurança microbiológica das maçãs, sugerindo novos estudos nesse sentido. Em maçãs minimamente processadas, o escurecimento enzimático é a principal causa de deterioração.

Produções elevadas de $\mathrm{CO}_{2}$ imediatamente após o corte e decréscimo na evolução do $\mathrm{CO}_{2}$ durante o período de armazenamento têm sido relatadas por vários autores. Bastrash et al. (1993) observaram em experimento com floretes de brócolos que a atividade respiratória foi 40\% superior após 7 horas do processamento mínimo, sendo que esta atividade decresceu durante os 6 primeiros dias de armazenamento a $4^{\circ} \mathrm{C}$.

Segundo Vicentini (1999) o comportamento da taxa de respiração durante armazenamento foi semelhante para a testemunha e para inflorescência de couve-flor com película de fécula de mandioca $2 \%$. As taxas de respiração, que no início do armazenamento era de 19,25 e 14,28 mg CO $\mathrm{kg}^{-1} \cdot \mathrm{h}^{-1}$, respectivamente para testemunha e película de fécula cairam para 9,50 e $12,34 \mathrm{mg} \mathrm{CO} 2 \cdot \mathrm{kg}^{-1} \cdot \mathrm{h}^{-1}$ no $7^{\circ}$ dia de armazenamento, elevando-se em seguida e atingindo no $13^{\circ}$ dia 27,33 e $23,73 \mathrm{mg} \mathrm{CO} \cdot \mathrm{kg}^{-1} \cdot \mathrm{h}^{-1}$. No entanto, as inflorescências recobertas com película de fécula de mandioca 4\%, no período analisado, apresentaram elevação linear da taxa respiratória no decorrer do armazenamento, passando de 8,66 para $15,32 \mathrm{mg} \mathrm{CO} \cdot \mathrm{kg}^{-1} \cdot \mathrm{h}^{-1}$, ao final de 13 dias. A taxa de respiração foi menor para as inflorescências com película de fécula de mandioca 4\% quando comparadas aos outros dois tratamentos.

Laranjas Valência foram tratadas com um revestimento à base de celulose e goma-laca. Os frutos revestidos apresentaram menores 
concentrações de $\mathrm{O}_{2}$ interno e maiores concentrações de $\mathrm{CO}_{2}$ e etileno do que os não revestidos. Frutos com goma-laca apresentaram perdas de massa significativamente menores do que os frutos recobertos com celulose e frutos sem cobertura, enquanto que frutos tratados com celulose não retardaram a perda de água, comparados ao fruto não revestido (Baldwin et al., 1995).

\subsubsection{Etileno}

O etileno $\left(\mathrm{C}_{2} \mathrm{H}_{4}\right)$ é um fitohormônio atuante em fases diversificadas, como crescimento, desenvolvimento e senescência, mas principalmente no amadurecimento de frutas climatéricas. Esta substância é fisiologicamente ativa em baixas concentrações (menos que $0,1 \mu \mathrm{L} \mathrm{L}^{-1}$ ) (Kluge, 2002).

O hormônio do amadurecimento, como é conhecido o etileno, é encontrado nos espaços intercelulares e forma-se a partir do aminoácido metionina, via SAM (adenosilmetionina). O SAM é convertido à ACC (ácido aminociclopropano carboxílico), sendo catalisado pela enzima ACC sintase (Figura 1). O ACC é então oxidado a etileno através da ação da enzima ACC oxidase (Taiz \& Zeiger, 2004).

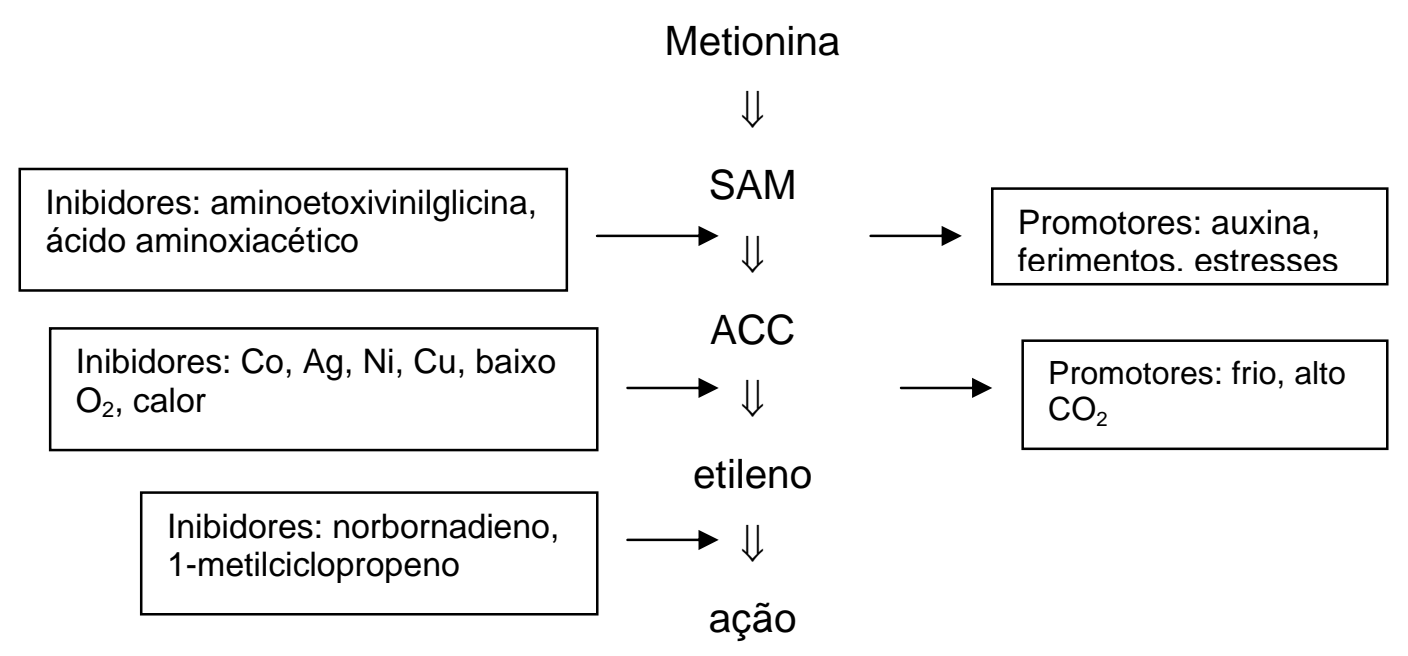

Figura 1 - Biossíntese e ação do etileno

Fonte: Kluge, 2002 
A síntese do etileno pode ser induzida por fatores externos como elevação da temperatura e injúrias mecânicas, promovendo sua atuação em sítios específicos nas células, usualmente ativando ou inibindo enzimas do ciclo metabólico dos tecidos. O etileno contribui para biossíntese de enzimas envolvidas em alterações bioquímicas e fisiológicas (Brecht, 1995).

O conhecimento do potencial de produção de etileno pelas frutas auxilia no manejo pós-colheita, uma vez que o armazenamento, numa mesma câmara frigorífica, de frutas com diferentes taxas de produção de etileno, reduzem a vida pós-colheita daquela que possui a menor taxa de produção, pois acelera a sua senescência (Kluge, 2002).

Baixas concentrações de $\mathrm{O}_{2}$ e elevadas de $\mathrm{CO}_{2}$, na atmosfera controlada, reduzem a síntese de etileno e diminuem a ação deste sobre o metabolismo dos frutos. A sensibilidade de frutos a ação do etileno ocorre em níveis de $\mathrm{O}_{2}$ acima de $8 \%$ e/ou $\mathrm{CO}_{2}$ abaixo de $1 \%$ (Kader, 1995).

Devido ao efeito acelerador no processo de maturação, métodos para a sua retirada do ambiente de armazenamento tornam-se importantes. O método mais simples para retirar o etileno do interior das câmaras consiste na ventilação da câmara fria. Entretanto, a admissão de ar externo afeta a temperatura e os níveis de $\mathrm{O}_{2}$ e $\mathrm{CO}_{2}$ no interior da câmara. Essas variações devem ser corrigidas rapidamente para fazer com que os frutos retornem às condições ideais de conservação (Awad, 1993). Outro método é a eliminação através de absorvedores, que é recomendado e utilizado nos EUA para retardar o processo de maturação de maçãs (Brackmann \& Chitarra, 1998).

O estresse causado pelo processamento de vegetais resulta em aumento da respiração e produção de etileno, aumentando a atividade de enzimas responsáveis pelo escurecimento, desenvolvimento de sabores e odores desagradáveis e amaciamento dos tecidos (Wiley, 1994). Varoquaux \& Wiley (1997) afirmam que a produção de etileno por frutas e hortaliças processadas pode chegar a ser 20 vezes maior quando comparadas com vegetais inteiros. 
A lesão dos tecidos de um vegetal provoca a perda ou redução da compartimentação celular (aumento da permeabilidade das membranas), o que ativa o sistema gerador de etileno, estimulando sua síntese, algumas vezes em poucos minutos. O etileno produzido em decorrência da lesão, também denominado de "etileno de ferimento" acelera a deterioração e a senescência dos tecidos vegetais (Brecht, 1995).

A via biossintética do "etileno de ferimento" é a mesma que ocorre na síntese normal durante a maturação. Sua ativação ocorre poucos minutos após a injúria dos tecidos pelo descascamento ou corte, particularmente no estádio pré-climatérico de frutos, sendo inversamente proporcional ao tamanho ou espessura da fatia do tecido vegetal (Chitarra, 2000).

O aumento da produção de etileno pode ser uma resposta hormonal e bioquímica devido ao estresse causado pelo corte. Isto ocorre, pois o primeiro alvo desse estresse é a membrana plasmática, a qual responde com mudanças em suas características físicas, de forma a contornar tais perturbações e tentar reparar os danos causados durante o processamento (Sakr et al.; 1997).

Tecidos vegetais injuriados induzem a elevação das taxas de produção de etileno, algumas vezes em poucos minutos, mas usualmente em cerca de 1 hora, com picos máximos entre 6 a 12 horas (Brecht, 1995). O etileno produzido no tecido injuriado acelera a sua senescência e deterioração.

Portela \& Cantwell (2001) observaram um aumento consistente na taxa de produção do etileno em pedaços de melões cortados com lâminas sem corte quando comparadas a pedaços obtidos com lâminas afiadas. Essa diferença, da ordem de $10 \%$ no início do experimento, atingiu valores acima de $30 \%$ no $6^{\circ}$ dia de armazenamento a $5^{\circ} \mathrm{C}$. Allong et al. (2001) não observaram efeito do fatiamento sobre a taxa de produção do etileno em mangas em nenhuma etapa do amadurecimento quando comparadas com frutas intactas. Eles atribuíram os resultados ao fato de esse fruto normalmente já produzi-lo em baixas concentrações. 
O fatiamento aumentou a respiração em morangos em $50 \%$ a $2,5^{\circ} \mathrm{C}$, mas não teve efeitos sobre a produção de etileno em baixas temperaturas, o que é típico de frutas não-climatéricas. O fatiamento em pêras parcialmente maduras (fruto climatérico), aumentou a respiração em $30 \%$ e reduziu produção de etileno a $2,5^{\circ} \mathrm{C}$ (Chitarra, 2002).

Não foi detectado etileno durante as 4 primeiras horas em beterrabas intactas e descascadas, sendo a produção de etileno gerada nestas condições considerada muito baixa $\left(<0,1 \mu \mathrm{L} \mathrm{C}_{2} \mathrm{H}_{4} \cdot \mathrm{kg}^{-1} \cdot \mathrm{h}^{-1}\right)$. Já para as beterrabas raladas, a produção de etileno nas primeiras horas após o corte atingiu valores da ordem de $0,90 \mu \mathrm{L} \mathrm{C}_{2} \mathrm{H}_{4} \cdot \mathrm{kg}^{-1} \cdot \mathrm{h}^{-1}$, havendo pouca variação ao longo das 4 horas de avaliação e durante o período de armazenamento (Vitti, 2003).

O etileno produzido pela ação física do processamento mínimo foi suficiente para acelerar o amaciamento em bananas e kiwis fatiados e acondicionados isoladamente (Abe \& Watada, 1991), ou quando em uma mesma embalagem (Watada et al., 1990).

\subsection{Processamento mínimo}

O processamento mínimo é definido como qualquer alteração física causada em frutas e hortaliças, que mantenha o estado fresco desses produtos. Este processamento inclui operações de seleção, lavagem, sanitização, descascamento, corte, centrifugação, embalagem, armazenamento e comercialização (Moretti, 1999).

Hortifrutícolas minimamente processados (MP) vêm ganhando uma proporção significativa do mercado de frutas e hortaliças in natura, desde a sua introdução nos canais de distribuição dos EUA, cerca de 30 anos atrás; e na França, no início da década de 80. Em 1997, a venda de produtos MP nos EUA alcançou US\$ 8 bilhões, com previsão de crescimento (FNP, 2000).

A utilização destes produtos no Brasil é recente, tendo iniciado no fim dos anos 80. Todavia, tem se observado um elevado crescimento nos últimos anos. Calcula-se que no ano de 1998, o setor tenha movimentado 450 milhões 
de reais. Na grande São Paulo, foi verificado um aumento de 200\% de 1998 a 1999 no volume de produtos MP comercializados no varejo (Moretti, 1999).

Nos últimos anos tem havido maior conscientização de produtores e distribuidores sobre a necessidade de suporte tecnológico, visando o melhor aproveitamento de vegetais que não alcançam padrão para comercialização (Melo, 2001). O processamento mínimo proporciona agregação de valor ao produto agrícola, aumentando a competitividade do setor de produção e possibilitando meios alternativos de comercialização (Chitarra, 1998).

A conservação de frutas e hortaliças minimamente processadas é um processo complexo, pois o vegetal continua fisiologicamente ativo e do processo participam as células vegetais danificadas, as intactas e as inativadas. Em outras palavras, algumas células se encontram respirando em velocidade normal, enquanto que as danificadas respiram a velocidades maiores (Rolle \& Chism, 1987).

Baldwin et al. (1995a) afirmam que as alterações por deterioração fisiológica nos MP ocorrem especialmente devido às injúrias nos tecidos, geralmente reduzindo o período de conservação. Essas injúrias nos tecidos dos vegetais resultam da manipulação e especialmente do processamento, como as injúrias mecânicas. Nessa ocasião ocorre contato maior entre as enzimas e substratos, induzindo reações enzimáticas indesejáveis, perda de íons e de outros compostos celulares e perda de umidade. Com a ruptura celular há maior disponibilidade de água para o desenvolvimento de microrganismos. Muitos vegetais defendem-se aumentando a respiração, a produção de etileno, a atividade das enzimas responsáveis pelo escurecimento e o desenvolvimento de sabores e odores desagradáveis e amolecimento dos tecidos.

A projeção da vida útil dos diferentes tipos de produtos MP varia entre 7 e 20 dias quando armazenados à temperatura recomendada (Watada \& QI, 1999). Nesses produtos, o controle da temperatura é uma das principais técnicas utilizadas para minimizar o efeito do corte. As temperaturas da sala de processamento e da água de sanitização devem ser próximas de $0^{\circ} \mathrm{C}$, a fim de 
reduzir a taxa respiratória e a produção de etileno, bem como outras reações associadas à senescência (Arruda, 2002). As perdas sensoriais podem ser reduzidas com a baixa temperatura, particularmente as provenientes de reações oxidativas nos pigmentos e lipídeos, bem como, haverá redução da velocidade das oxidações bioquímicas durante a senescência (Wiley, 1994).

A temperatura recomendada para o armazenamento de produtos MP é $0^{\circ} \mathrm{C}$, mesmo para aqueles com sensibilidade à injúria pelo frio. Para melancia $\mathrm{MP}$, no entanto, o armazenamento em temperatura de $2-3^{\circ} \mathrm{C}$ pode resultar em melhor vida útil do que o armazenamento a $0^{\circ} \mathrm{C}$ (Cantwell, 2000).

Para minimizar os efeitos deteriorativos, Wong et al. (1994) citam medidas como estocagem a baixas temperaturas, modificação ou controle da atmosfera e aplicação de coberturas comestíveis.

A atmosfera controlada inibe a atividade da polifenoloxidase (PFO) em cubos de maçãs minimamente processadas (Rocha \& Morais, 2001). Os autores verificaram que quanto mais elevada a concentração de $\mathrm{CO}_{2}$, maior a capacidade de inibição da PFO. Segundo Nicoli et al. (1994), o escurecimento enzimático em maçãs Golden Delicious pode ser inibido, com sucesso, pelo uso de embalagens com atmosfera modificada.

\subsubsection{Microbiologia em vegetais minimamente processados (MP)}

Os MP constituem ótimo meio de crescimento para os microrganismos, devido à lesão dos tecidos e ao alto teor de umidade dos vegetais acondicionados, o que aumenta seu potencial de deterioração. Por serem muito manipulados, esses produtos podem ter sua microbiota aumentada, alterada e eventualmente, veicular microrganismos patogênicos. Dentre os microrganismos encontrados em MP, podem ser destacados as leveduras, coliformes totais, coliformes fecais, bolores e mesófilos (Neguyen \& Carlin, 1994).

Para frutas e hortaliças MP não há informações na legislação brasileira quanto aos limites de contagens tolerados para microrganismos. A Resolução 
RDC n¹2 de 02 de janeiro de 2001 (Brasil, 2001) prevê padrões microbiológicos para hortaliças e frutas frescas, in natura, preparadas (descascadas, selecionadas ou fracionadas), sanificadas, refrigeradas ou congeladas, para o consumo direto, de ausência em $25 \mathrm{~g}$ para Salmonella sp, e $10^{2} \mathrm{NMP} / \mathrm{g}$ para coliformes a $45^{\circ} \mathrm{C}$.

\subsubsection{Coliformes totais e fecais}

Os coliformes totais são compostos por bactérias da Família Enterobacteriaceae, capazes de fermentar lactose produzindo ácido e gás em um período de $24-48$ horas a $32-37^{\circ} \mathrm{C}$. São bastonetes Gram negativos, não esporulados, sendo aeróbios ou anaeróbios facultativos (Silva et al., 1997). Fazem parte deste grupo bactérias pertencentes aos gêneros Escherichia, Klebsiella, Serratia, Hafnia e Citrobacter (Calci et al., 1998). Destes, apenas Escherichia coli tem como habitat primário o trato intestinal do homem $\mathrm{e}$ animais. Os demais, além de serem encontrados em fezes, também estão presentes em outros ambientes como nos vegetais, ou no solo, onde persistem por tempo superior ao de bactérias patogênicas de origem intestinal como Salmonella e Shigella (Ribeiro et al., 1991).

Cerca de $95 \%$ dos coliformes existentes nas fezes humanas e de outros animais são Escherichia coli. Esta bactéria é o melhor indicador de contaminação fecal conhecido até o momento, pois satisfaz todas as exigências de um indicador ideal de contaminação (Silva et al., 2000).

A presença de coliformes totais indica condições higiênicas insatisfatórias, com provável contaminação pós-processamento; deficiência nos processos de limpeza, sanificação e tratamento térmico; e ainda, multiplicação durante o processamento ou a estocagem (Silva Junior et al., 2001).

Dessa forma torna-se importante a sanitização de toda planta de processamento, inclusive dos instrumentos e equipamentos utilizados, bem como a utilização de luvas, máscaras, aventais e botas por parte dos 
operadores, o uso de água clorada para a lavagem dos vegetais, controle rigoroso da temperatura e utilização de matéria-prima de qualidade.

O número de coliformes encontrados por diferentes autores em cenoura, chicória e repolho minimamente processado na forma de "tiras" e armazenado a $8^{\circ} \mathrm{C}$ por 1 dia situou-se na faixa de $10^{4}-10^{5}$ UFC (Fantuzzi, 1999). Barriga et al. (1991) encontraram uma relação linear entre o número de microrganismos em alface minimamente processada em tiras e o decréscimo na qualidade visual durante o armazenamento.

\subsubsection{Salmonella}

As Salmonellas são membros da família Enterobacteriaceae, são bacilos Gram negativos que crescem aerobicamente e anaerobicamente em temperaturas ótimas de $37^{\circ} \mathrm{C}$ e são prontamente exterminadas em temperaturas acima de $55^{\circ} \mathrm{C}$. Podem ser isoladas do intestino das pessoas e dos animais, atingindo alimentos direta ou indiretamente, através dos excrementos animais na hora do abate, através do excremento das pessoas, ou de águas poluídas por dejetos; também nas cozinhas, podem ser transferidas dos alimentos crus para os cozidos através das mãos, superfícies, utensílios e outros equipamentos (Hobbs \& Roberts, 1999).

No estudo de Pilon (2003) o resultado de análises microbiológicas realizadas em cenoura e salada mista MP foi negativo para presença de Salmonella, coliformes totais e fecais.

\subsection{Revestimentos comestíveis em alimentos}

A utilização de filmes e revestimentos comestíveis para prolongar a vida útil dos alimentos não é um procedimento recente. O revestimento de laranjas e limões com ceras para retardar a perda de água destes frutos foi praticada na China entre os séculos XII e XIII (Donhowe \& Fennema, 1994). 
$\mathrm{Na}$ Inglaterra, no século $\mathrm{XVI}$, era comum a prática de se revestir alimentos com materiais gordurosos para diminuir a velocidade de desidratação destes produtos (Labuza \& Contreras-Medellin, 1981).

Ao longo do século XIX foram desenvolvidos alguns tipos de revestimentos a base de gelatina para preservação de carnes, como as patentes de Kester \& Fennema (1986). Em meados de 1930 já estava disponível comercialmente um revestimento de parafina para frutos cítricos, utilizados para retardar a perda de água. No início de 1950, uma emulsão de cera de canaúba era empregada para revestir frutos e vegetais frescos (Kaplan, 1986).

Atualmente, filmes e coberturas são usados em uma variedade de aplicações, incluindo revestimento para lingüiça, coberturas de chocolate para nozes e frutas, e coberturas para frutas e vegetais. Entretanto, as informações técnicas envolvidas estão longe das adequadas, deixando aos cientistas de alimentos a tarefa de desenvolver filmes e coberturas específicas e eficientes para cada tipo de alimento (Donhowe \& Fennema, 1994).

Cobertura comestível é definida como uma fina camada de material comestível, depositada em um alimento como revestimento, que vem sendo utilizada para estender a vida pós-colheita de vegetais. Sua finalidade é inibir ou reduzir a migração de umidade, oxigênio, dióxido de carbono, aromas, dentre outros, pois promovem barreiras semi-permeáveis. Além disso, podem transportar ingredientes alimentícios como antioxidantes, antimicrobianos e flavorizantes e/ou melhorar a integridade mecânica ou as características de manuseio do alimento (Krochta \& Mulder-Johnston, 1997).

A maior vantagem do uso dessas coberturas é que podem ser consumidas juntamente com o alimento. Permitem a retenção de aditivos, promovendo uma resposta funcional mais significativa na superfície do produto; o controle da incorporação de óleos e solutos aos alimentos durante o processamento (Guilbert, 1988). Por estarem em contato com os alimentos, é desejável que filmes e coberturas comestíveis apresentem propriedades 
organolépticas neutras (transparente, inodoro, insípido), de modo a não alterar as características sensoriais dos alimentos (Gontard, 1991). Coberturas a base de hidrocolóides apresentam geralmente características organolépticas mais neutras do que os formados a partir de lipídeos ou derivados, os quais apresentam maior opacidade e sabor residual (Gontard \& Guilbert, 1996).

As coberturas e filmes comestíveis são elaborados tendo como base as macromoléculas biológicas (biopolímeros) capazes de formar uma matriz contínua, homogênea e coesa (Kester \& Fennema,1986). De acordo com Cuq et al. (1995a), coberturas são as que formam a matriz diretamente sobre os alimentos, diferentemente dos filmes, que são matrizes pré-formadas separadamente do alimento.

Para a formação de coberturas comestíveis é necessária a dispersão ou solubilização das macromoléculas em um solvente (água, etanol ou ácidos orgânicos) para se obter uma solução filmogênica, que será a seguir aplicada diretamente sobre o produto. O processo se completa com a evaporação do solvente ou secagem (Gontard, 1994).

Os biopolímeros mais utilizados na elaboração de filmes e coberturas comestíveis são as proteínas (gelatina, caseína, ovoalbumina, glúten de trigo, zeína, proteínas miofibrilares), os polissacarídeos (amido e seus derivados, pectina, celulose e seus derivados, alginato, carragena) e os lipídeos (monoglicerídeos acetilados, ácido esteárico, ésteres de ácido graxo) (Cuq et al., 1995a).

As coberturas elaboradas a partir de polissacarídeos ou proteínas possuem excelentes propriedades mecânicas e ópticas, porém são sensíveis à umidade e apresentam alto coeficiente de permeabilidade ao vapor d'água. Ao contrário, as coberturas compostas de lipídeos apresentam boas propriedades de barreiras ao vapor d’água, mas são opacas e pouco flexíveis, além de apresentar sabor residual, que pode influenciar as características organolépticas do alimento (Gallo et al., 2000). 
O cloreto de cálcio também pode ser incorporado nas coberturas para melhorar a textura e coloração dos produtos alimentícios, além de induzir a geleificação de algumas coberturas como o alginato (Baldwin et al., 1995b).

As coberturas podem ser feitas de base simples ou compostas, utilizando materiais diferentes. Encontram-se como simples camada, dupla camada ou multicamadas (Guilbert et al., 1996).

Krochta \& Mulder-Johnston (1997) definem filmes e coberturas de dupla camada como sendo formados por uma camada de filme com propriedades de barreira a oxigênio e aromas e uma segunda camada, hidrofóbica, protegendo o produto através da propriedade de barreira a umidade. Já os filmes compostos são aqueles que associam mais de um material na sua composição. Cita-se como exemplo os filmes usados como barreira à umidade, que geralmente requerem em suas composições materiais hidrofóbicos como ácidos graxos e ceras comestíveis.

Wong et al. (1994) estudaram os efeitos da cobertura de dupla camada, uma de polissacarídeos e outra de lipídeo, na difusão de gases e a composição gasosa interna em pedaços de maçãs. Os polissacarídeos testados foram: carragena, pectina, celulose e alginato. $O$ acetaldeído monoglicerídeo foi utilizado como base lipídica. Além da aplicação da cobertura, os pedaços de maçã foram tratados com solução contendo ácido ascórbico (1\%), ácido cítrico $(0,5 \%)$, cloreto de cálcio $(0,25 \%)$ e cloreto de sódio $(2 \%)$. Todas as combinações testadas apresentaram maior resistência ao vapor d'água que a testemunha. Também foi observada redução na produção de gás carbônico e etileno em todas as combinações, com destaque para a produção de etileno, sendo que nesses tratamentos houve redução de $90 \%$ em relação à testemunha. Não houve diferença significativa entre esses tratamentos a $1 \%$.

\subsubsection{Uso de dextrina como cobertura comestível}

As dextrinas apresentam muitas aplicações industriais e alimentícias. $\mathrm{Na}$ área alimentar, as dextrinas entram no preparo de alimentos, como agente 
espessante e têm aplicações em cervejarias, panificação, sucos e bebidas à base de cacau, licores destilados, produtos de confeitaria (Cereda \& Vilpoux, 2003).

As dextrinas ou maltodextrinas são polissacarídeos de menor peso molecular, derivados da hidrólise do amido. A degradação pode ser via ácida ou enzimática, ou ainda ocorrer pela combinação destes dois métodos (Kerr, 1950). Na sua composição é encontrado uma mistura contendo glicose, maltose, maltotriose e outros sacarídeos, cujo valor de Dextrose Equivalente (DE) é inferior a 20, ou seja, um grau de hidrólise menor que os xaropes de glicose e maltose (Alexander, 1992).

O processo mais simples de hidrólise do amido é a via ácida, em que uma pasta de amido com concentração em torno de $50 \%$ em massa seca, recebe ácido, geralmente $\mathrm{HCl}$ concentrado, na proporção de 0,1 a 0,2\% sobre o peso seco de amido. Esta suspensão é então submetida à ação do calor por período de tempo que depende do processo. Quando é utilizado ácido clorídrico a neutralização é feita com $\mathrm{NaOH}$, resultando em $\mathrm{NaCl}$, que é solúvel e proporciona xarope mais transparente que a hidrólise com ácido sulfúrico. A neutralização com carbonato de cálcio gera gesso (sulfato de cálcio), que é insolúvel. A formação de $\mathrm{NaCl}$, entretanto, tem a desvantagem de proporcionar sabor salgado ao produto e exigir o tratamento em coluna de resina de troca iônica para sua remoção. A hidrólise com ácido sulfúrico exige uma filtração mais fina mas, em compensação, não requer tratamento com resina de troca iônica (Cereda \& Vilpoux, 2003).

Krochta \& Mulder-Johnston (1997) utilizaram dextrinas como coberturas em amêndoas e obtiveram resultado satisfatório do revestimento como barreira à umidade. Em maçãs cortadas o resultado obtido por estes mesmos autores foi positivo como barreira ao oxigênio. 


\subsubsection{Uso de fécula de mandioca como cobertura comestível}

As coberturas tendo o amido como biopolímero de formação começaram a ser estudadas de forma mais intensiva nos últimos anos. A fécula de mandioca têm sido freqüentemente testada como matéria-prima para este fim em função da sua transparência e baixo custo. A obtenção da cobertura de fécula baseia-se no princípio da geleificação da mesma sob condições de altas temperaturas e excesso de água, seguida de retrogradação (Cereda et. al, 1992).

Para Medcalf (1973) a geleificação, ocorre quando o amido aquecido em excesso de água. Com o aumento da temperatura, ocorre o rompimento da estrutura do grânulo, extravasando os seus constituintes que se transformam em substâncias gelatinosas, denominada gel de amido. Admite-se que o gel é formado pela amilopectina, retendo em sua estrutura a amilose. A temperatura na qual se dá a geleificação varia com o tipo de amido. De acordo com Cereda (1995) na retrogradação pontes de hidrogênio são estabelecidas e o material disperso volta a se organizar em macromolécula, originando uma cobertura protetora em volta do fruto.

Cereda (1995) estudaram o pós-colheita de bananas variedade Nanicão utilizando coberturas de fécula de mandioca nas concentrações 3 e 6\% e de sacos de polietileno com 10 micras de espessura, selados. Os frutos tratados com cobertura de fécula apresentaram comportamento semelhante à testemunha, revelando que para banana, a eficiência da cobertura em retardar a maturação foi menor do que os sacos de polietileno. O maior problema observado nos frutos tratados com cobertura foi a evolução anormal da cor, permanecendo manchas verdes nos frutos amarelos.

Henrique \& Cereda (1996) estudaram o desverdecimento de limões Siciliano com Ethrel a 0, 1000, 2000 e 3000 mg.l-1 e sua conservação póscolheita quando revestidos por cobertura de fécula de mandioca. Os frutos receberam suspensões de fécula nas concentrações de 0, 1, 2 e 3\% e foram armazenados em temperatura média de $24^{\circ} \mathrm{C}$ e umidade relativa de $60 \%$. O 
melhor resultado foi obtido com a cobertura na concentração 3\%, que proporcionou maior brilho e redução da perda de água do fruto, não alterando sua composição química, porém o desverdecimento do fruto foi parcial. Neste tratamento, após 10 dias de armazenamento a cobertura começou a se soltar do fruto. As coberturas elaboradas com suspensões a $2 \%$, proporcionaram menor brilho, porém o desverdecimento foi completo em todas as concentrações de Ethrel, e a cobertura demorou mais tempo para se soltar do fruto.

Vicentini et al. (1998a) estudaram frutos de pimentão cV. Magali com coberturas de fécula de mandioca 1 e 3\%, armazenados em temperatura ambiente. Os frutos com coberturas em ambas as concentrações, apresentaram perda de massa igual à da testemunha, sendo que, neste caso, a maior vantagem do uso das coberturas foi retardar a mudança de coloração do fruto. No mesmo trabalho foi constatado que a cobertura não favoreceu o desenvolvimento de patógenos.

Cereda et al. (1992) avaliaram a viabilidade do uso de coberturas de amido (milho e mandioca) sem qualquer aditivo, como substitutas das ceras comerciais sintéticas em mamão. As coberturas foram aplicadas em frutos inteiros e estes foram armazenados em condições ambientais por duas semanas. Os resultados mostraram que a utilização das coberturas de amido de milho e de fécula de mandioca não ocasionaram os efeitos nocivos que o tratamento com ceras geram como alteração de sabor do fruto, colapso interno do fruto ocasionado pela espessura grossa da película, além de serem igualmente efetivas na redução da perda de peso dos frutos. Porém, a cobertura de fécula de mandioca proporcionou aos frutos melhor aparência que o amido de milho, com brilho atrativo. Em função disto, a fécula de mandioca se destacou entre os produtos estudados como matéria-prima para a elaboração das coberturas comestíveis.

Oliveira (1996) usou cobertura de fécula de mandioca nas concentrações de 1 a $2 \%$ em frutos de goiaba cv. Kumagai armazenados em 
temperatura ambiente $\left(19,5-27^{\circ} \mathrm{C}\right)$ e comparou estes tratamentos com goiabas tratadas com cera "sta-fresh" (1:9) e com frutos sem tratamento. Os frutos recobertos com fécula apresentaram menor perda de massa em relação à testemunha, porém maior do que os frutos tratados com cera "sta-fresh". Este mesmo autor observou que, tanto os frutos tratados com cera "sta-fresh" quanto os com cobertura de fécula de mandioca apresentaram taxas respiratórias menores que o da testemunha.

Vieira et al. (2000) aplicaram cobertura de fécula de mandioca a 1, 2 e $3 \%$ em abacaxi cortado em pedaços. Foram observadas variações inexpressivas nos índices de sólidos solúveis, acidez, pH, perda de massa fresca e textura dos abacaxis minimamente processados por 7dias.

\subsubsection{Uso de alginato como cobertura comestível}

Alginatos são polímeros estruturais de alto peso molecular encontrados na parede celular e espaço intercelular de algas marrons Phaeopyceae (Onsoyen, 1997), sendo as espécies mais utilizadas para a sua produção comercial as Macrocystis pyrifera, Ascophyllum nodosum, Laminaria hyperborea e Laminaria digitada (Dziezak, 1991).

Os alginatos são polímeros lineares com peso molecular variando de 20.000 a 600.000 Daltons. O ácido algínico é um ácido poliurônico constituído por monômeros de ácidos D- Manurônico e L- Gulurônico, ligados por ligações glicosídicas do tipo 1,4 (Onsoyen, 1997). Não são solúveis em água, mas os sais de sódio, potássio, amônio são, enquanto que os de cálcio não. É um polissacarídeo autodegradável quando aquecido por tempo prolongado. A viscosidade aumenta em $\mathrm{pH}$ abaixo de 4 e também pela presença de íons de cálcio ou cátions polivalentes, chegando a formar géis. Os alginatos formam filmes e possuem algumas propriedades que os tornam semelhantes à pectina (Bobbio, 1984).

O ácido algínico possui solubilidade limitada, podendo ser transformado em uma grande variedade de alginatos comerciais pela incorporação de 
diferentes sais como cálcio, potássio, magnésio e sódio, sendo esta última, a forma mais utilizada e hidrofílica (Onsoyen, 1997).

Alginatos de sódio são compatíveis com um grande número de compostos utilizados em alimentos como amidos, dextrinas, sacarose, pectinas, proteínas como caseína e polióis. São também parcialmente compatíveis com etanol e sais como sulfato de sódio, cloreto de sódio e incompatíveis com ácidos fortes, que reduzem o pH a valores abaixo de 3,5 (Macdowell, 1973).

As coberturas de alginato são formadas pela evaporação de uma solução de alginato seguida pela formação de ligações cruzadas iônicas com um sal de cálcio. Elas são impermeáveis a óleos e gorduras, entretanto são barreiras deficientes quanto à umidade (Whistler et al., 1984). As coberturas de gel de alginato podem reduzir significativamente a perda de umidade dos alimentos, isto porque a umidade é perdida pela cobertura antes do alimento se desidratar significativamente. Coberturas de alginato são boas barreiras ao oxigênio (Whistler et al., 1997), podem retardar a oxidação lipídica dos alimentos e melhorar o sabor, textura e a adesão (Kester \& Fennema, 1986).

Existem trabalhos com aplicação de alginato como barreira à umidade e ao oxigênio em produtos panificáveis e massas recheadas, como retentor de sabor, de cor e de textura de camarões congelados e para adesividade em pães (Krochta \& Mulder-Johnston, 1997).

Baldwin et al. (1996) testaram coberturas a base de carboximetilcelulose (CMC) adicionada de proteína concentrada de soja e de peptona de soja em maçãs e batatas cortadas. Em relação à permeabilidade ao oxigênio a $\mathrm{CMC}$ + proteína de soja e a $\mathrm{CMC}$ + peptona de soja não apresentaram diferença significativa a 5\%. Contudo, esses dois tratamentos diferenciaram-se da testemunha, na mesma intensidade, apresentando menor permeabilidade ao oxigênio. Já na permeabilidade ao vapor d'água, todos os tratamentos diferenciaram-se significativamente a 5\%, com destaque de menor permeabilidade para a CMC + peptona de soja. Em relação ao escurecimento enzimático, destacou-se a solução de CMC + proteína de soja com pH 3,5 mais 
antioxidantes. Durante três semanas, ambas as coberturas a base de CMC adicionadas de sorbato de potássio e antioxidantes se destacaram, respectivamente, quanto ao tratamento antimicrobiano e como preventivo do escurecimento enzimático.

A aplicação por aspersão de cobertura comestível a base de celulose foi estudada por Howard \& Dewi (1995) em cenouras minimamente processadas, por aspersão. As amostras com aplicação de cobertura a 0,87L/min tiveram menor esbranquecimento e coloração mais intensa.

O uso de cobertura de alginato de sódio em bulbo de alho armazenado a $20^{\circ} \mathrm{C}$ por 14 dias foi eficiente como barreira à perda de umidade do vegetal (Nussinovitch et al., 1996).

\subsection{Solução conservadora}

Os principais compostos químicos utilizados em produtos minimamente processados são os antioxidantes, os acidulantes, os agentes quelantes (Chitarra, 2000).

O uso de antioxidantes evita o escurecimento dos tecidos, a perda do aroma e do sabor, bem como as mudanças na textura e a redução da qualidade nutricional. A eficiência depende de fatores ambientais (luz, temperatura, oxigênio), $\mathrm{pH}$ do meio, tipo e atividade dos sistemas enzimáticos, tipo de produto vegetal. São utilizados o ácido ascórbico (e seus sais de cálcio e potássio), isoascórbico ou eritórbico (e seus sais de sódio), ácido cítrico e o EDTA (ácido dissódico e cálcio dissódico). Atuam como doadores de hidrogênio, evitando oxidação e fenólicos presentes no vegetal (Chitarra, 2000).

$\mathrm{O}$ uso de acidulantes abaixa $\mathrm{O} \mathrm{pH}$ do produto, sendo efetiva notadamente em hortaliças com faixa de $\mathrm{pH}$ entre 5 e 6 , nas quais a deterioração microbiana é rápida. São utilizados ácidos orgânicos naturais como o ácido cítrico, o málico, o lático e o tartárico, entre outros. Atuam como agentes fungicidas ou fungistáticos, enquanto que outros são mais eficientes na inibição do crescimento de bactérias (Chitarra, 2000). 
A acidificação é uma medida segura, também utilizada para frutos e hortaliças minimamente processados. Sua ação é relacionada ao abaixamento direto do $\mathrm{pH}$ do substrato, alguma redução do $\mathrm{pH}$ interno da célula devido à ionização da molécula ácida não dissociada, ou modificação do mecanismo de transporte das membranas celulares (Chitarra, 2000).

Os agentes quelantes são os compostos mais importantes para estabilizar frutos e hortaliças minimamente processados, pois os agentes redutores e certos agentes que se ligam com metais (ação quelante) e que atuam na preservação de reações oxidativas. Os mais utilizados são ácido cítrico e o EDTA (ácido etileno diamino tetracético) bem como seus sais de cálcio e dissódico que auxiliam na manutenção da cor, do sabor e da textura (Chitarra, 2000).

O ácido ascórbico previne o escurecimento e outras reações oxidativas. Sua adição em conjunto com o ácido cítrico tende a manter o pH do meio mais estável (mais ácido). Também atua como quelante (seqüestrador) de enzimas oxidativas (PPO) (Chitarra, 2000).

O ácido ascórbico é um composto redutor moderadamente forte; de natureza ácida, forma sais neutros com bases e é muito solúvel em água. O uso de inibidores do escurecimento em frutos processados é restrito a componentes que sejam não tóxicos e que não prejudiquem o sabor e aroma do produto. $\mathrm{O}$ ácido ascórbico, além de ser muito efetivo na redução do escurecimento, é também reconhecido como seguro, barato e bem aceito pelos consumidores (Miranda, 2001).

O uso do ácido ascórbico como antioxidante, além de ser totalmente seguro para o consumo humano, pode aumentar o teor de vitamina $\mathrm{C}$ de certas frutas e hortaliças (Préstamo \& Manzano, 1993).

Kader (1995) estudou maçãs "Fuji" fatiadas e tratadas com 2\% de ácido ascórbico e armazenadas em atmosfera modificada com baixo nível de oxigênio. Observaram que, independente da atmosfera testada, o tratamento 
com ácido ascórbico reduziu o escurecimento e aumentou a vida útil de maças fatiadas.

$\mathrm{O}$ ácido cítrico $\left(\mathrm{C}_{6} \mathrm{H}_{8} \mathrm{O}_{7}\right)$ é um dos principais ácidos orgânicos naturais em frutos. Previne o escurecimento enzimático pela ação sobre polifenoloxidases e peroxidases. Também é utilizado para potenciar (ação sinergista) outros antioxidantes como o ácido ascórbico (Chitarra, 2000).

A atividade antimicrobiana do ácido cítrico é devida à sua capacidade quelante de íons metálicos, os quais são essenciais para o crescimento microbiano. A inativação de enzimas e potenciação de antioxidantes em frutos e hortaliças como os ácidos ascórbico e eritórbico ou eritorbato de sódio, podem ser conseguidos pelo uso do ácido cítrico (Chitarra, 2000).

Segundo Noguchi \& Watada (1997) a respiração de cenouras minimamente processadas pode ser reduzida pelo tratamento com ácido cítrico, o que pode, conseqüentemente, estender a vida de prateleira desse produto.

A estabilização de produtos minimamente processados tem sido realizada com o auxílio de agentes redutores e agentes quelantes em adição ao abaixamento da temperatura e ao uso de atmosfera modificada. No entanto, outros meios de preservação também estão sendo testados, como a imersão ou pulverização de solução de cloreto de cálcio em diferentes concentrações. Tem sido testado principalmente em frutos, mas também é eficiente em hortaliças. $O$ cálcio atua retardando a maturação e a senescência dos tecidos vegetais, por auxiliar na manutenção da estrutura das paredes celulares, ao se ligar com as pectinas para formar o pectato de cálcio (insolúvel), conferindo textura mais firme aos tecidos (Chitarra, 2000).

Os efeitos do cálcio nos frutos têm recebido especial atenção, visto que as aplicações desse cátion produzem efeitos positivos no retarda da senescência, mediante a diminuição da respiração e da produção de etileno no complexo membrana-parede celular, como também no controle dos distúrbios fisiológicos e na conservação dos frutos (Awad, 1993). Além disso, trata-se de 
um produto natural, barato, comestível e aprovado pela FDA (Food and Drug Administration) para uso pós-colheita (Conway et al., 1995).

O efeito do cálcio nos frutos é extenso, visto que suas mudanças fisiologias após a colheita são contínuas. O cálcio é a parte crítica da estrutura da parede celular, à qual confere rigidez pela formação de ligações cruzadas na matriz polissacarídica péctica. A formação de ligações cruzadas de cálcio entre ácidos urônicos torna a parede celular menos acessível a enzimas que ocasionam o amaciamento, mantendo a firmeza e o aumento de resistência à invasão por certos microrganismos (Miranda, 2001).

A produção de etileno é estimulada em tecidos deficientes de cálcio e sua adição diminui a taxa respiratória e suprime a produção de etileno. O cálcio reduz a taxa de respiração limitando a difusão de substrato que se origina do vacúolo para as enzimas que participam da respiração no citoplasma (Rolle \& Chism, 1987).

Em maçãs, o tratamento com cálcio ajudou a reter a firmeza do fruto e a reduzir a liberação do $\mathrm{CO}_{2}$ e do etileno (Conway \& Sams, 1984).

Segundo Miranda (2001) estudando mamão minimamente processando verificou que o tratamento com $\mathrm{CaCl}_{2}$ foi o que apresentou maior perda de massa, demonstrando não ser efetivo no controle deste parâmetro.

$\mathrm{O}$ tratamento com $\mathrm{CaCl}_{2}$ é muito efetivo em prevenir o amolecimento de kiwis fatiados, sendo indispensável o seu uso para melhor conservação (Massantini \& Kader, 1995).

A conservação pelo uso do sal ( $\mathrm{NaCl})$ é um dos métodos mais antigos de conservação de alimentos. A eficácia do processo é devido ao aumento da pressão osmótica e conseqüente diminuição da atividade de água afetando assim o crescimento microbiano (Potter, 1968).

Wong et al. (1994) propuseram o uso de solução conservadora (ácido ascórbico, ácido cítrico, cloreto de cálcio e cloreto de sódio) para vegetais MP. As principais funções esperadas desta solução são evitar ou minimizar o escurecimento dos tecidos, a perda do aroma e do sabor, mudanças na textura, 
redução na qualidade nutricional, além de propriedades antimicrobianas. Posteriormente, Fontes et al. (2003) testaram a solução de Wong et al. (1994) em maçãs MP e verificaram através de análise sensorial, que a concentração proposta de $\mathrm{NaCl}$ promovia alteração no sabor do produto. De acordo com os autores, a concentração ideal para não proporcionar sabor residual perceptível pelos provadores foi de $0,7 \%$.

\subsection{Análise sensorial}

Análise Sensorial é uma ciência usada para evocar, medir, analisar e interpretar reações às características dos alimentos e materiais como são percebidas pelos sentidos da visão, olfato, gosto, tato e audição (ABNT,1993).

A identificação e mensuração das propriedades sensoriais é fator essencial para o desenvolvimento de novos produtos alimentícios, reformulação de produtos já existentes, identificação de alterações causadas por métodos de processamento, armazenagem e uso de novos ingredientes, assim como, para a manutenção de normas de controle de qualidade (Ferreira et al., 2000).

A Análise Descritiva Quantitativa (ADQ) proporciona uma completa descrição de todas as propriedades sensoriais de um produto (aparência, aroma, sabor e textura) representando um dos métodos mais completos e sofisticados para a caracterização sensorial de atributos. Esta análise trabalha com provadores treinados através dos próprios atributos do produto em questão. Além disso, os provadores têm total liberdade para criar sua terminologia sobre os atributos envolvidos com o produto (Dutcosky, 1996).

Segundo Stone \& Sidel (1985), a ADQ consiste primeiramente no recrutamento dos provadores, obtendo-se as informações necessárias para o líder da equipe. Posteriormente, é realizado o treinamento com testes de sensibilidade com os gostos básicos (doce, salgado, ácido, amargo, umami). E para finalizar é feito um treinamento e desenvolvimento da terminologia descritiva a fim da uniformização dos termos para realização do teste sensorial (Lyon et al., 1992). 
A lista dos termos descritivos pode ser realizada utilizando-se o método tradicional ou de rede. O método tradicional oferece o produto a cada provador da equipe sensorial, solicitando que ele faça uma lista completa dos atributos sensoriais que caracterizam o produto. Em seguida, sob a supervisão de um líder, a lista dos termos descritos de cada provador é discutida com toda a equipe sensorial. Os termos mais utilizados para descrever o produto irão compor a ficha de análise descritiva do produto que está sendo avaliado (Dutcosky, 1996).

O método de rede (ou Grid) consiste em apresentar amostras aos pares a cada provador. Os provadores são solicitados a avaliar as amostras e listar as similaridades e diferenças entre elas. Em seguida, sob a supervisão de um líder, os termos descritivos desenvolvidos por todos os provadores são discutidos com a equipe sensorial. Em seqüência, uma ficha de análise descritiva do produto é composta pelos termos mais usados por todos os provadores para descrever as semelhanças e diferenças entre as amostras (Dutcosky, 1996).

A função do líder da equipe sensorial é facilitar a discussão e entendimento entre provadores, fornecer materiais de referência para a equipe sensorial, definir consensualmente a escolha de cada termo descritivo e ao final, com a participação dos provadores, desenvolver a ficha terminológica que será utilizada na ADQ (Dutcosky, 1996). 


\section{MATERIAL E MÉTODOS}

\subsection{Material}

As maçãs utilizadas foram da cultivar Royal Gala, cedidas pela Cooperativa Regional Agropecuária Serrana (COOPERSERRA), de São Joaquim, no Estado de Santa Catarina. As frutas foram colhidas e armazenadas em câmara fria a $2^{\circ} \mathrm{C}$. O transporte para a Companhia de Entrepostos e Armazéns Gerais de São Paulo (CEAGESP) foi realizado em caminhão baú convencional sem refrigeração. Do CEAGESP as frutas foram encaminhadas à ESALQ/USP, em Piracicaba/SP, onde foram processadas e avaliadas.

Para os tratamentos das maçãs MP foram utilizados, além da solução conservadora, os produtos comerciais: crystal gum, fécula de mandioca, protanal RF6650.

A solução conservadora foi a proposta por Fontes et al. (2003) composta de ácido ascórbico (1\%), ácido cítrico (0,5\%), $\mathrm{CaCl}_{2}(0,25 \%)$ e $\mathrm{NaCl}$ $(0,7 \%)$.

Crystal gum é o nome comercial da dextrina de fécula de mandioca, produzida e cedida pela National Starch, de São Paulo-SP. De acordo com a empresa (Crystal Gum, 2002) este produto apresenta as características de boa claridade e sabor brando, forma filmes com resistência a rachaduras e lascas, o $\mathrm{pH}$ é aproximadamente 3 e a umidade 7\%. Sua viscosidade é baixa quando quente e, diferentemente de outros produtos comumente usados para formar filme, possui pouca ou nenhuma tendência a espumar durante aquecimento ou encolher no resfriamento. Como possui a propriedade de formar filme, pode ser usado como substituto da goma arábica em processos de cobertura para 
confeitos e também como verniz não pegajoso para bolos, balas, nozes e frutas. O processo de obtenção é por hidrólise do amido por via ácida, sendo o seu DE (dextrose equivalente) igual a 13.

A fécula de mandioca utilizada é da marca comercial Yoki, adquirida em comércio local.

O Protanal-RF6650, é o nome comercial do alginato de sódio (E-401) cedido pela FMC BioPolymer, Limeira-SP. O alginato é um hidrocolóide solúvel em água, extraído de algas marinhas marrons e seu pH está entre 6 e 8. Suas propriedades funcionais são as de agente gelificante, espessante, estabilizante e formadores de películas para alimentos (FMC BioPolymer, 2000). A geleificação do alginato, entretanto, é dependente da quantidade de cálcio presente ou adicionado ao alimento (King, 1983).

Através de avaliação toxicológica a FAO estabeleceu valores de Ingestão Diária Aceitável (IDA) para diversos aditivos. Para o alginato de sódio e a dextrina a Resolução $n^{0} 386$ (05/08/1999) especifica quantidade sem prescrição (q.s.p), o que significa que não existe limitação de uso, ou seja, podem ser utilizada quantidade suficientes para obter o efeito tecnológico necessário.

\subsection{Metodologia}

\subsubsection{Processamento das maçãs}

As maçãs selecionadas foram primeiramente lavadas, descascadas e cortadas em cubos de aproximadamente $2 \times 2 \mathrm{~cm}$ (aproximadamente $6 \mathrm{~g}$ de peso) com auxílio de facas de aço inoxidável. Todo procedimento foi realizado de acordo com as boas práticas de higiene e manipulação, em ambiente a $15^{\circ} \mathrm{C}$.

Foram utilizados 5 tratamentos, dentre os quais o controle, que constou de maçãs cortadas (MP). O segundo tratamento constou de maçãs MP e imersas imediatamente em solução conservadora contendo ácido ascórbico 
(1\%), ácido cítrico (0,5\%), cloreto de cálcio $(0,25 \%)$ e cloreto de sódio $(0,7 \%)$, por 2 minutos.

Nos tratamentos com revestimentos, as maçãs MP foram tratadas primeiramente com solução conservadora por 2 minutos, e posteriormente imersas na solução formadora de película por 2 minutos. As maçãs assim tratadas seguiram para secagem, realizada com auxílio de ventilador em ambiente refrigerado $\left(15^{\circ} \mathrm{C}\right)$ por 30 minutos. O material foi, então, acondicionado em bandejas de poliestireno (isopor) de $(13 \times 18 \mathrm{~cm})$, que por sua vez, foram envoltas em filme de PVC. Em cada bandeja foram acondicionados 16 pedaços de maçã MP, resultando em peso médio de cada bandeja com amostra de $100 \mathrm{~g}$. Concluído o procedimento, as maçãs MP foram mantidas sob refrigeração $\left(2^{\circ} \mathrm{C}\right)$ por até 13 dias.

O processamento das maçãs MP foi conduzido conforme o fluxograma apresentado na Figura 2. 


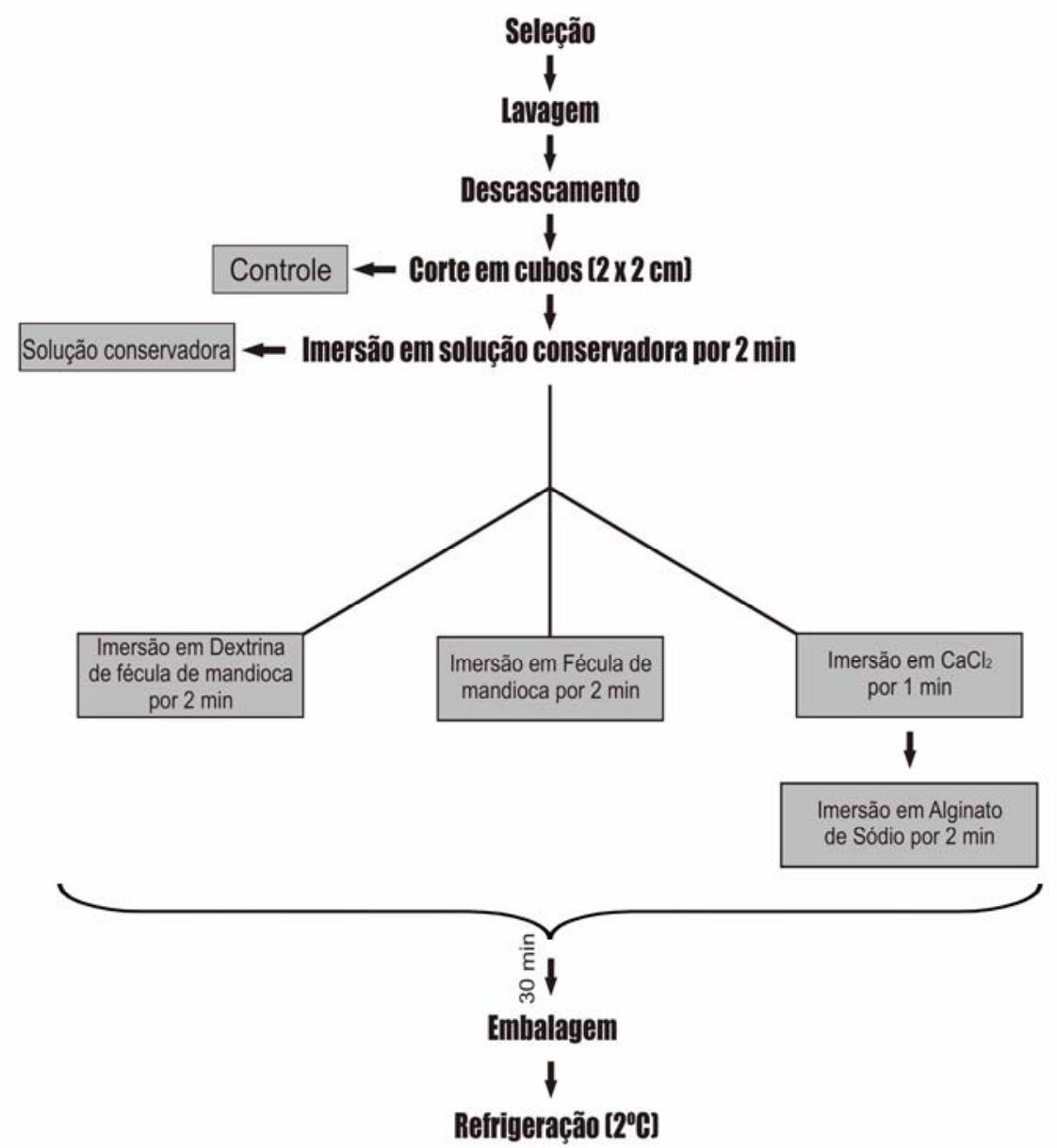

Figura 2 - Fluxograma do processamento das maçãs MP

O tratamento com dextrina de fécula de mandioca foi realizado, conforme testes prévios, na concentração de 5,5\%. A dextrina foi solubilizada em água destilada mediante aquecimento a $70^{\circ} \mathrm{C}$, sob agitação constante, e posterior resfriamento até a temperatura $15^{\circ} \mathrm{C}$.

No tratamento com fécula de mandioca foi utilizada suspensão a $3 \%$. A formação de gel foi realizada mediante adição de água destilada e aquecimento a $70^{\circ} \mathrm{C}$, sob agitação constante e posterior resfriamento até $15^{\circ} \mathrm{C}$.

No caso do tratamento com alginato de sódio, as maçãs MP receberam primeiramente a aplicação de solução de cloreto de cálcio a 0,6\%, por imersão 
durante 1 minuto para promover a geleificação do alginato de sódio a 2\%, que foi aplicado, na seqüência, também por imersão. A solubilização do alginato de sódio em água destilada se deu previamente pelo aquecimento da suspensão até $70^{\circ} \mathrm{C}$ e posterior resfriamento até $15^{\circ} \mathrm{C}$.

\subsubsection{Aspecto superficial das maçãs MP}

Um corte fino da superfície de um pedaço de maçã MP foi realizado com auxílio de lâmina inoxidável, após 1 dia de armazenamento. Este material foi fixado sobre "stubs" utilizando-se fitas adesivas dupla face e recoberto com ouro (40-50nm) por 210 segundos em metalizador da marca Balzers.

O aspecto superficial das maçãs MP que receberam banho de imersão em solução filmogênica (dextrina, fécula de mandioca e alginato de sódio) foi observado em microscópio eletrônico de varredura (Zeiss - DSM 940 A).

\subsubsection{Análises fisiológicas}

\subsubsection{Taxa respiratória}

Para quantificar o $\mathrm{CO}_{2}$ liberado pelas maçãs inteiras ou minimamente processadas (controle, solução conservadora, dextrina, fécula de mandioca e alginato de sódio), estas foram acondicionadas em frascos de vidro de 600mL. Foram utilizadas 5 repetições de cada tratamento, com aproximadamente $120 \mathrm{~g}$ de maçã por frasco. Os frascos, tampados com filme PVC foram armazenados por 13 dias em câmaras de B.O.D, a $2^{\circ} \mathrm{C}$. Foram realizadas determinações diárias do teor de $\mathrm{CO}_{2}$ liberado. No momento da avaliação, os frascos eram hermeticamente fechados com tampa de metal e septo de silicone por 30 minutos e amostras de $1 \mathrm{~mL}$ de gás do interior dos frascos eram coletadas utilizando-se seringa modelo Gastight, marca Hamilton de 2,5mL. As amostras eram injetadas em cromatógrafo a gás (modelo Trace 2000/GC, marca Thermoffinigan), equipado com coluna Porapack $\mathrm{N}$ de $2 \mathrm{~m}$ de comprimento, metanador e detetor de ionização de chama. O hidrogênio foi utilizado como 
gás de arraste a $40 \mathrm{~mL}$. $\mathrm{min}^{-1}$. As temperaturas mantidas no aparelho foram de $100^{\circ} \mathrm{C}$ no injetor, $100^{\circ} \mathrm{C}$ para a coluna, $250^{\circ} \mathrm{C}$ no detetor e $350^{\circ} \mathrm{C}$ no metanador. $\mathrm{O} \mathrm{CO}_{2}$ foi quantificado pela calibração com padrões de $2150 \mu \mathrm{L} \mathrm{CO}_{2} \mathrm{~L}^{-1} \mathrm{e}$ $29900 \mu \mathrm{L} \mathrm{CO} \mathrm{CO}_{2} \mathrm{~L}^{-1}$. Para o cálculo da respiração foram considerados o volume do frasco, a massa dos frutos e o tempo de acúmulo de $\mathrm{CO}_{2}$. A taxa respiratória foi expressa em $\mathrm{mL} \mathrm{CO} \mathrm{Kg}^{-1} \cdot \mathrm{h}^{-1}$.

\subsubsection{Produção de etileno}

O procedimento para determinação da produção de etileno foi o mesmo utilizado para determinação da taxa respiratória. A única diferença foi a temperatura do metanador que para esta determinação foi de $100^{\circ} \mathrm{C}$. O etileno foi quantificado pela calibração com padrão de $1,94 \mu \mathrm{L} \mathrm{C}_{2} \mathrm{H}_{4} \cdot \mathrm{L}^{-1}$. Os resultados foram expressos em $\mu \mathrm{L} \mathrm{C}_{2} \mathrm{H}_{4} . \mathrm{Kg}^{-1} \cdot \mathrm{h}^{-1}$.

\subsubsection{Análises físicas e físico-químicas}

As maçãs MP revestidas ou não com coberturas comestíveis, foram mantidas sob refrigeração a $2^{\circ} \mathrm{C}$ e avaliadas após $1,5,9$ e 13 dias de armazenamento. Nestes períodos as avaliações realizadas foram teor de umidade, textura, teor de sólidos solúveis, pH, acidez total titulável e cor das amostras.

\subsubsection{Umidade}

O teor de umidade das maçãs foi determinado por gravimetria de acordo com as normas analíticas do Instituto Adolfo Lutz (1986). Foi utilizada estufa a $105^{\circ} \mathrm{C}$, com circulação de ar, até peso constante.

\subsubsection{Textura}

A dureza das amostras foi avaliada em texturômetro "Texture Test System", modelo TP-1 acoplado a um registrador automático de variação de força, operando em célula padrão de compressão de cisalhamento CS-1, com 
10 lâminas de $1 / 8$ polegadas de espessura e ângulo de $90^{\circ}$. As amostras foram previamente pesadas (aproximadamente $50 \mathrm{~g}$ ) e colocadas na célula teste de cisalhamento e compressão, de tal forma que as lâminas das células tivessem ação paralela às amostras. Foi utilizado o sensor em 300lbf (libras-força) e a velocidade de descida do pistão foi de $20 \mathrm{~cm} / \mathrm{min}$.

A força máxima de cisalhamento foi obtida da carta do registrador multiplicada pelo fator de posição do sensor eletrônico (3 no caso do sensor utilizado) e dividida pelo peso da amostra. Os resultados foram expressos em $\mathrm{lbf} / \mathrm{g}$.

\subsubsection{Teor de sólidos solúveis totais}

As maçãs MP foram prensadas em prensa manual e com uma alíquota do extrato aquoso foi feita a leitura do teor de sólidos solúveis totais em refratômetro da marca Atago (modelo PR-101). Os resultados foram expressos em ${ }^{\circ}$ Brix, após correção de temperatura para $20^{\circ} \mathrm{C}$.

\subsubsection{4 pH}

O valor de $\mathrm{pH}$ das maçãs MP foi medido em extrato aquoso (20g da amostra triturada em homogeneizador com $100 \mathrm{~mL}$ de água), em potenciômetro da marca Tecnopon, segundo metodologia ditada pela AOAC (1992).

\subsubsection{Acidez total titulável}

A acidez total titulável foi determinada e calculada como o volume

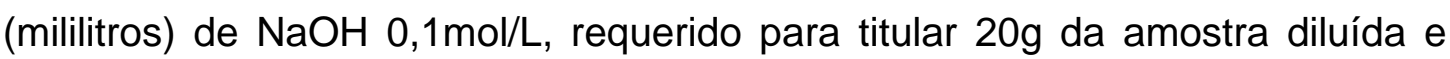
homogeneizada em $100 \mathrm{~mL}$ de água e expressa em porcentagem de ácido málico (AOAC, 1992).

\subsubsection{Cor}

A cor das amostras foi avaliada utilizando-se o Colorímetro Minolta, modelo Chroma Meter CR-200b. Foram utilizados 5 pedaços de maçãs em 
cada tratamento, realizando-se uma leitura por pedaço. As amostras foram avaliadas no sistema L, a* e b* (Bible \& Singha, 1993).

\subsubsection{Análises microbiológicas}

Maçãs MP de todos os tratamentos foram avaliados quanto à presença de coliformes totais e fecais aos 1, 5, 9 e 13 dias após o processamento. As análises foram realizadas em triplicata.

No dia do processamento foi realizada análise para Salmonella com os pedaços de maçã MP sem solução conservadora e sem cobertura.

\subsubsection{Preparo da amostra}

A unidade analítica utilizada para a análise de maçã MP foi $25 \mathrm{~g}$, retirada assepticamente da amostra e transferida para um agitador estéril com $225 \mathrm{~mL}$ de água peptonada $0,1 \%$, utilizada para fazer diluições decimais seriadas subseqüentes. Foram realizadas diluições de $10^{-1}$ a $10^{-3}$.

\subsubsection{Contagem de coliformes totais e fecais}

Para a contagem de coliformes totais e fecais (Escherichia coli) foi utilizada a técnica de tubos múltiplos, série de três tubos. A partir das diluições decimais obtidas $\left(10^{-1}\right.$ a $\left.10^{-3}\right)$ foi inoculado $1 \mathrm{~mL}$ das diluições $10^{-1}$ a $10^{-3}$ numa série de três tubos contendo o meio Caldo Lauril Sulfato Triptose suplementado com 50mg/L de 4-metil-umbeliferil- $\beta$-D-glucuronídeo LST-MUG (Merck), com tubos de Durham invertidos no interior. Os tubos foram incubados a $35^{\circ} \mathrm{C}$ por 24 horas e a leitura foi feita sob lâmpada de luz ultravioleta ( 6 w e $\lambda=365 \mathrm{~nm}$ ) em cabine escura. Foram considerados positivos para E. coli, todos os tubos que apresentaram fluorescência azul (Vanderzant \& Splittstoesser, 1992).

Para confirmação de coliformes totais, o conteúdo dos tubos suspeitos do LST-MUG (formação de gás nos tubos de Durham) foi transferido com alça microbiológica para tubos com caldo Verde Brilhante Bile (VB, Merck) e incubados a $35^{\circ} \mathrm{C}$ por $24 / 48 \mathrm{~h}$. Foram considerados positivos os tubos que 
apresentaram crescimento e formação de gás (Vanderzant \& Splittstoesser, 1992).

O número mais provável por mililitro $(\mathrm{NMP} / \mathrm{mL})$ foi obtido em uma tabela NMP apropriada às diluições inoculadas, sendo o resultado expresso em NMP/g (Vanderzant \& Splittstoesser,1992).

\subsubsection{Salmonella}

A metodologia utilizada para determinação de Salmonella constou da pesagem de $25 \mathrm{~g}$ da amostra, permanência da mesma à temperatura ambiente por 1 hora e posterior incubação a $36^{\circ} \mathrm{C} \pm 1^{\circ} \mathrm{C}$ por 16 a $20 \mathrm{~h}$, finalizando-se assim a etapa de pré-enriquecimento. Para enriquecimento seletivo, foi inoculada uma alíquota de $0,1 \mathrm{~mL}$ do caldo de pré-enriquecimento em caldo Rappaport Vassiliadis e de alíquotas de $1 \mathrm{~mL}$ em caldo Selenito Cistina e caldo Tetrationato. A partir desse cultivo, os tubos a $41^{\circ} \mathrm{C} \pm 0,5^{\circ} \mathrm{C}$ foram incubados, em banho maria com agitação, por 24 a 30h. O caldo de enriquecimento seletivo foi semeado em estrias na superfície das placas ágar Rambach, ágar MLCB (Manitol Lysine Crystal Violet Brilhant Green Agar), ágar BPLS (Brilhant Green Phenol Red Lactose Sucrose Agar) e ágar XLD (Xylose Lisine Agar), para obtenção de colônias isoladas. As placas foram incubadas invertidas, a $36^{\circ} \mathrm{C} \pm 1^{\circ} \mathrm{C}$, por 18 a 24 horas (Bennett et al., 1999).

Para as provas preliminares, cada colônia suspeita foi inoculada em ágar TSI (Triple Sugar Iron Agar) e ágar LIA (Lysine Iron Agar), através de picada profunda e estriamento. Paralelamente, foram inoculados em ágar BHI (Brain Heart Infusion) ágar inclinado para verificação de pureza e manutenção da cepa. Incubou-se a $36^{\circ} \mathrm{C} \pm 1^{\circ} \mathrm{C}$ por 18 a 24 horas. Para provas complementares, partiu-se de colônias crescidas em ágar BHI, na qual foram inoculadas as colônias com as respostas esperadas de Salmonella sp em ágar TSI e ágar LIA, e em meios para produção de urease, utilização de malonato, descarboxilação da lisina, utilização de citrato, desaminação da fenilalanina, meio SIM, fermentação da lactose, fermentação do manitol, reação de VM-VP - 
Voges Proskauer. Para provas confirmatórias, as colônias suspeitas de Salmonella $s p$ foram submetidas às provas de reação de oxidase, reação de PYRase, prova da catalase e sorologia. O resultado foi expresso como presença ou ausência em $25 \mathrm{~g}$ ou $\mathrm{mL}$ de amostra (Bennett et al., 1999).

\subsubsection{Análise sensorial}

Inicialmente o projeto foi avaliado pelo Comitê de Ética em Pesquisa, na Faculdade de Odontologia de Piracicaba (UNICAMP/FOP) e foi aprovado por estar de acordo com a Resolução 196/96 do Conselho Nacional de Saúde (Anexo A).

A análise foi desenvolvida no Laboratório de Análise Sensorial do Departamento de Agroindústria, Alimentos e Nutrição, da ESALQ/USP. O teste sensorial utilizado foi a Análise Descritiva Quantitativa (ADQ) com provadores selecionados e treinados segundo Stone (1992). Os resultados foram submetidos à análise de variância pelo Teste $\mathrm{F}$ e comparação de médias pelo Teste de Tukey (5\%) utilizando-se o sistema analítico SAS (Statistical Analysis System, 1989).

Para aplicação da ADQ, várias etapas foram desenvolvidas. Inicialmente foi realizado um recrutamento, que consiste em uma etapa na qual se faz o primeiro contato com os provadores através de uma ficha, obtendo informações de interesse, disponibilidade de tempo e afinidade pelo produto (Figura 3). A ficha foi preenchida por 22 provadores, constituindo-se de professores, técnicos, alunos do Departamento de Agroindústria, Alimentos e Nutrição (ESALQ/USP). 


\section{FICHA DE RECRUTAMENTO}

Estamos convidando você a participar do treinamento para Análise Sensorial de Maçã Minimamente Processada pelo método da "Análise Descritiva Quantitativa", a qual deve identificar e quantificar seus diferentes atributos sensoriais. Para este treinamento serão necessárias 2 seções por semana de aproximadamente 15 minutos cada, durante um período de 2 meses, contamos com você para a formação desta nova equipe de provadores.

\section{Identificação}

Nome:

Idade: $15-25(\quad)$

$25-35()$

Email:

$35-45()$

Telefone para contato:

$45-55(\quad)$

\section{Horários disponíveis}

\begin{tabular}{|r|l|l|l|l|l|}
\hline & segunda & terça & quarta & quinta & sexta \\
\hline Manhã 8:00-10:00hs & & & & & \\
\cline { 2 - 6 } 10:00-11:30hs & & & & & \\
\hline $\begin{array}{r}\text { Tarde 14:00-16:00hs } \\
\text { 16:00-17:30hs }\end{array}$ & & & & & \\
\cline { 2 - 6 } & & & & & \\
\hline
\end{tabular}

\section{Hábitos}

Fumante sim não

Toma freqüentemente cafezinho $\operatorname{sim}$ não

Hábitos Alimentares

Você consome maçã $\operatorname{sim}$ não, com que freqüência?

1 vez por semana

2 a 4 vezes por semana

diariamente

outros

\section{Exercícios de escalas}

Marque com um traço vertical para indicar a proporção da área pintada de cada desenho.

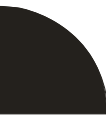

nenhuma

toda
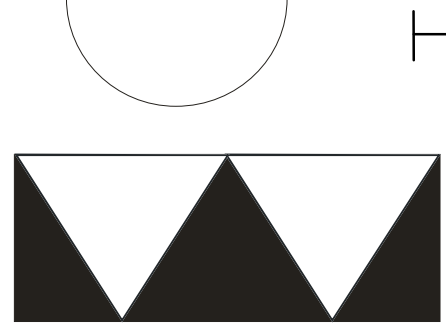

nenhuma

toda

Figura 3 - Ficha de recrutamento de provador 
Após o recrutamento, os 22 provadores realizaram o teste de reconhecimento dos gostos básicos. Para essa fase foram utilizadas soluções quimicamente puras dos gostos básicos: doce (2\% de sacarose), ácido (0,07\% de ácido cítrico), salgado (0,2\% de cloreto de sódio) e amargo (0,07\% de cafeína) e neutro (água mineral). Foram oferecidos $25 \mathrm{~mL}$ de cada solução aos provadores em copos de plásticos descartáveis, codificados com números aleatórios de 3 algarismos.

Este teste foi realizado em cabines individuais, com luz vermelha. Cada cabine continha as amostras, fichas de avaliação (Figura 4), copo com água para lavagem da boca entre as avaliações. Apenas os provadores que acertaram todos os gostos básicos continuaram o treinamento.

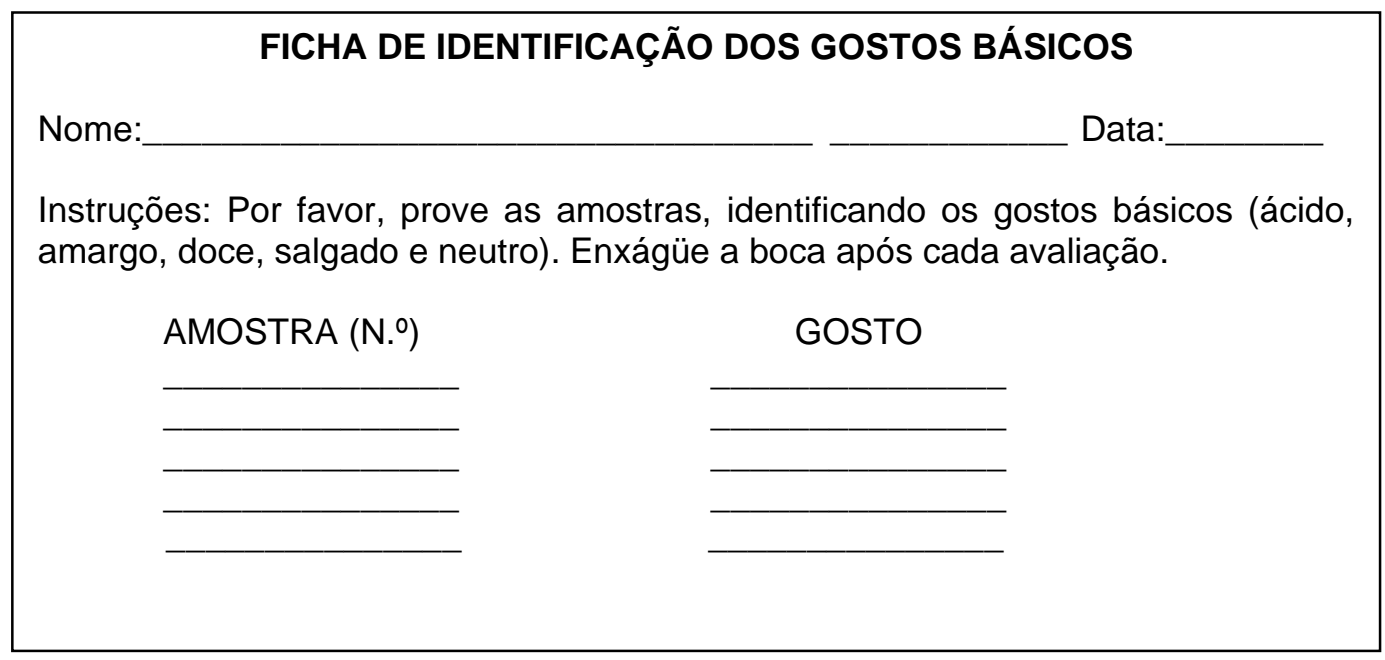

Figura 4 - Modelo da ficha de reconhecimento dos gostos básicos

Os 12 provadores aprovados no teste de reconhecimento dos gostos básicos seguiram para o teste de sensibilidade para gosto, em que foi utilizado o teste triangular com o uso dos tratamentos da própria dissertação (controle, solução conservadora, dextrina, fécula de mandioca, alginato de sódio). O teste triangular (Figura 5) foi conduzido 5 vezes nas mesmas condições descritas para o teste de reconhecimento dos gostos básicos. 


\section{FICHA DO TESTE TRIANGULAR}

Nome: Data:

Você está recebendo três amostras codificadas. Duas amostras são iguais e uma é diferente. Por favor, prove da esquerda para a direita com intervalo de 20 segundos entre as amostras e indique a amostra diferente, fazendo um círculo ao redor do número. Lave a boca após provar cada amostra.

1)

2)

3)

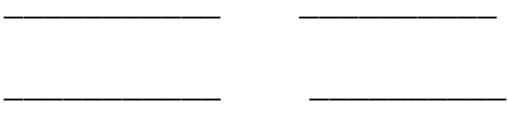

Figura 5 - Modelo da ficha do teste triangular

Foram selecionados apenas os provadores que acertaram mais de $80 \%$ em todos os testes realizados. Com isso, apenas 10 provadores continuaram a fase de treinamento, sendo 6 mulheres e 4 homens.

A etapa seguinte constou do desenvolvimento de terminologia e treinamento. Inicialmente, os provadores avaliaram sensorialmente todos os tratamentos, em cabines individuais e verbalizaram as sensações percebidas em relação à aparência, aroma, sabor e textura na ficha de levantamento de atributos (Figura 6).

Após a etapa de descrição das similaridades e diferenças entre as amostras, uma discussão em grupo foi conduzida sob a supervisão de um líder, com o objetivo de agrupar os termos semelhantes que melhor descrevessem as amostras de maçãs MP e foi sugerido material de referência, que auxiliou a equipe a perceber as características sensoriais do produto avaliado e ancorar os extremos das escalas de intensidade (Figura 7). 
FICHA DE LEVANTAMENTO DE ATRIBUTOS

Nome:

Data:

Por favor, avalie cada uma das amostras quanto à aparência, aroma, sabor e textura e desenvolva termos que melhor descrevem as amostras com relação a cada um desses atributos sensoriais.

APARÊNCIA:

AROMA:

SABOR:

TEXTURA:

Figura 6 - Modelo da ficha de levantamento de atributos

$\mathrm{Na}$ reunião foi elaborada uma ficha de definição de cada termo descritivo (Figura 8) desenvolvido pela equipe sensorial treinada que foi utilizada em conjunto com a ficha de avaliação da sensorial (Figura 9). Para a medida da intensidade de cada atributo foi utilizada uma escala não estruturada de $10 \mathrm{~cm}$, variando de nada (nota 0) e muito (nota 10) (Spoto, 1989).

Os provadores foram treinados utilizando os parâmetros definidos na reunião, em cabines individuais com luz branca e as amostras foram codificadas com três dígitos. Além das cinco amostras que foram apresentadas aos provadores, também foi solicitado pelos provadores um pedaço de maçã recém cortado para comparação. 


\section{AGRUPAMENTO DOS TERMOS}

APARÊNCIA

- Cor característica de maçã: característico de maçã (5), amarelo claro (3), amarelada (3), branco leitoso (1);

- Escurecimento: cor escura (5), amarronzada (5), oxidada (1), cor clara (4), ferrugem (1);

- Uniformidade de cor: homogêneo (5), heterogêneo (5), manchas escuras (4), uniforme (5);

- Brilho: brilho (6), opaco (4), sem brilho (5);

- Umidade: ressecada (4), úmida (7), suculenta (5);

- Aparência artificial: natural (4), artificial (5), gelatinosa (3), melada (2), película (2), fresca (5), passada (4);

\section{AROMA}

- Característico maçã: característico de maçã (6), natural (4), gelatina (1), estranho (3);

- Doce: doce (7), suave (3);

- Ácido: ácido (8);

\section{SABOR}

- Característico maçã: característico de maçã (8), artificial (3), estranho (3);

- Doce: doce (8), natural (4);

- Salgado: salgado (8);

- Ácido: azedinho (3), ácido (9);

- Fruta fresca: natural (6), fresca (4), passada (4);

- Amargo: amargo (8);

\section{TEXTURA}

- Característico maçã: característico de maçã (7), natural (5);

- Maciez: firme (6), consistente (4), macio (5);

- Umidade: seca (3), farinhenta (4), porosa (3), natural (5), suculenta (4), crocância $(4)$; 


\begin{tabular}{|c|c|c|}
\hline APARÊNCIA & DEFINIÇÃO & REFERÊNCIA \\
\hline $\begin{array}{l}\text { cor característica } \\
\text { de maçã }\end{array}$ & $\begin{array}{l}\text { Refere-se à cor característica da maçã } \\
\text { recém cortada. }\end{array}$ & $\begin{array}{l}\text { Pouco: maçã cortada e deixada } \\
\text { por } 24 \text { horas. } \\
\text { Muito: maçã recém cortada. }\end{array}$ \\
\hline escurecimento & $\begin{array}{l}\text { Refere-se ao escurecimento que } \\
\text { ocorre em maçãs cortadas devido à } \\
\text { oxidação. }\end{array}$ & $\begin{array}{l}\text { Pouco: maçã recém cortada. } \\
\text { Muito: maçã cortada e deixada } \\
\text { por } 24 \text { horas. }\end{array}$ \\
\hline $\begin{array}{l}\text { uniformidade de } \\
\text { cor }\end{array}$ & $\begin{array}{l}\text { Refere-se à homogeneidade da } \\
\text { coloração da maçã recém cortada. }\end{array}$ & $\begin{array}{l}\text { Pouco: maçã cortada e deixada } \\
\text { por } 24 \text { horas, presença de } \\
\text { manchas. } \\
\text { Muito: maçã recém cortada. }\end{array}$ \\
\hline brilho & $\begin{array}{l}\text { Refere-se na característica da maçã } \\
\text { refletir ou absorver luz. }\end{array}$ & $\begin{array}{l}\text { Pouco: maçã recém cortada. } \\
\text { Muito: maçã com película. }\end{array}$ \\
\hline umidade & $\begin{array}{l}\text { Refere-se à umidade existente na } \\
\text { maçã recém cortada. }\end{array}$ & $\begin{array}{l}\text { Pouco: maçã ressecada, seca. } \\
\text { Muito: maçã natural, suculenta. }\end{array}$ \\
\hline $\begin{array}{l}\text { aparência } \\
\text { artificial }\end{array}$ & $\begin{array}{l}\text { Refere-se à maçã com características } \\
\text { diferentes da maçã recém cortada. }\end{array}$ & $\begin{array}{l}\text { Pouco: maçã recém cortada. } \\
\text { Muito: maçã cortada e deixada } \\
\text { por } 2 \text { dias. }\end{array}$ \\
\hline \multicolumn{3}{|l|}{ AROMA } \\
\hline $\begin{array}{l}\text { característico de } \\
\text { maçã }\end{array}$ & $\begin{array}{l}\text { Refere-se ao aroma característico da } \\
\text { fruta recém cortada. }\end{array}$ & $\begin{array}{l}\text { Pouco: maçã com película. } \\
\text { Muito: maçã recém cortada. }\end{array}$ \\
\hline doce & $\begin{array}{l}\text { Refere-se ao aroma doce da fruta } \\
\text { recém cortada. }\end{array}$ & $\begin{array}{l}\text { Pouco: maçã com película. } \\
\text { Muito: maçã recém cortada. }\end{array}$ \\
\hline ácido & $\begin{array}{l}\text { Refere-se ao aroma ácido da fruta } \\
\text { recém cortada. }\end{array}$ & $\begin{array}{l}\text { Pouco: maçã com película. } \\
\text { Muito: maçã recém cortada. }\end{array}$ \\
\hline \multicolumn{3}{|c|}{ 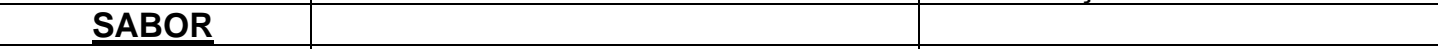 } \\
\hline $\begin{array}{l}\text { característico de } \\
\text { maçã }\end{array}$ & $\begin{array}{l}\text { Refere-se ao sabor da fruta recém } \\
\text { cortada. }\end{array}$ & $\begin{array}{l}\text { Pouco: maçã com película. } \\
\text { Muito: maçã recém cortada. }\end{array}$ \\
\hline doce & $\begin{array}{l}\text { Refere-se ao sabor doce da fruta } \\
\text { recém cortada. }\end{array}$ & $\begin{array}{l}\text { Pouco: maçã com película. } \\
\text { Muito: maçã recém cortada. }\end{array}$ \\
\hline salgado & $\begin{array}{l}\text { Refere-se em caracterizar se existe } \\
\text { um teor de sal nas maçãs. }\end{array}$ & $\begin{array}{l}\text { Pouco: maçã recém cortada. } \\
\text { Muito: maçã imersa em solução } \\
\text { de NaCl. }\end{array}$ \\
\hline ácido & $\begin{array}{l}\text { Refere-se ao sabor ácido da fruta } \\
\text { recém cortada. }\end{array}$ & $\begin{array}{l}\text { Pouco: maçã com película. } \\
\text { Muito: maçã recém cortada. }\end{array}$ \\
\hline amargo & $\begin{array}{l}\text { Refere-se em caracterizar se existe } \\
\text { um amargor nas maçãs. }\end{array}$ & $\begin{array}{l}\text { Pouco: maçã recém cortada. } \\
\text { Muito: maçã imersa em solução } \\
\text { de cafeína. }\end{array}$ \\
\hline fruta fresca & $\begin{array}{l}\text { Refere-se ao sabor de fruta recém } \\
\text { cortada. }\end{array}$ & $\begin{array}{l}\text { Pouco: maçã cortada e deixada } \\
\text { por } 5 \text { dias. } \\
\text { Muito: maçã recém cortada. }\end{array}$ \\
\hline \multicolumn{3}{|l|}{ TEXTURA } \\
\hline $\begin{array}{l}\text { característica de } \\
\text { maçã }\end{array}$ & $\begin{array}{l}\text { Refere-se à textura característica da } \\
\text { fruta recém cortada. }\end{array}$ & $\begin{array}{l}\text { Pouco: maçã cortada e deixada } \\
\text { por } 5 \text { dias. } \\
\text { Muito: maçã recém cortada. }\end{array}$ \\
\hline maciez & $\begin{array}{l}\text { Refere-se a maciez da fruta cortada e } \\
\text { deixada por } 5 \text { dias. }\end{array}$ & $\begin{array}{l}\text { Pouco: maçã recém cortada. } \\
\text { Muito: maçã cortada e deixada } \\
\text { por } 5 \text { dias. }\end{array}$ \\
\hline umidade & $\begin{array}{l}\text { Refere-se a umidade da fruta recém } \\
\text { cortada. }\end{array}$ & $\begin{array}{l}\text { Pouco: maçã cortada e deixada } \\
\text { por } 5 \text { dias. } \\
\text { Muito: maçã recém cortada. }\end{array}$ \\
\hline
\end{tabular}

Figura 8 - Ficha de definição dos atributos realizada pelos provadores 
Nome: Data

Você está recebendo amostras de maçã minimamente processadas. Por favor, avalie as amostras em relação à aparência, aroma, sabor e textura de acordo com a escala abaixo.

\begin{tabular}{|l|c|c|c|c|c|c|c|c|c|c|}
\hline 0 & 1 & 2 & 3 & 4 & 5 & 6 & 7 & 8 & 9 & 10 \\
\hline
\end{tabular}

\section{APARÊNCIA}

a) cor característica de maçã

$\begin{array}{ll}\text { Amostra } & \text { Nota } \\ \text { Amostra } & \text { Nota } \\ \text { Amostra } & \text { Nota } \\ \text { Amostra } & \text { Nota } \\ \text { Amostra } & \text { Nota }\end{array}$

c) uniformidade de cor

$\begin{array}{ll}\text { Amostra } & \text { Nota } \\ \text { Amostra } & \text { Nota } \\ \text { Amostra } & \text { Nota } \\ \text { Amostra } & \text { Nota } \\ \text { Amostra } & \text { Nota }\end{array}$

e) umidade

$\begin{array}{ll}\text { Amostra } & \text { Nota } \\ \text { Amostra } & \text { Nota } \\ \text { Amostra } & \text { Nota } \\ \text { Amostra } & \text { Nota } \\ \text { Amostra } & \text { Nota }\end{array}$

f) aparência artificial

Amostra

Amostra

Amostra

Amostra

Amostra b) escurecimento Amostra _ Nota Amostra — Nota Amostra — Nota Amostra Nota Amostra $\longrightarrow$ Nota

d) brilho

$\begin{array}{ll}\text { Amostra } & \text { Nota } \\ \text { Amostra } & \text { Nota } \\ \text { Amostra } & \text { Nota } \\ \text { Amostra } & \text { Nota } \\ \text { Amostra } & \text { Nota }\end{array}$

Comentários gerais sobre aparência:

a) característico de maçã

Amostra

Amostra

Amostra

Amostra

Amostra

Nota

Nota _ Qual?

Nota Qual?

Nota Qual?

Nota Qual?

Nota Qual?

c) ácido

$\begin{array}{ll}\text { Amostra } & \text { Nota } \\ \text { Amostra } & \text { Nota } \\ \text { Amostra } & \text { Nota } \\ \text { Amostra } & \text { Nota } \\ \text { Amostra } & \text { Nota }\end{array}-$

\section{AROMA}

Figura 9 - Ficha da análise descritiva quantitativa das maçãs MP 


\section{SABOR}

a) característico de maçã

$\begin{array}{ll}\text { Amostra } & \text { Nota } \\ \text { Amostra } & \text { Nota } \\ \text { Amostra } & \text { Nota } \\ \text { Amostra } & \text { Nota } \\ \text { Amostra } & \text { Nota } \\ & \\ \text { salgado } & \\ \text { Amostra } & \text { Nota } \\ \text { Amostra } & \text { Nota } \\ \text { Amostra } & \text { Nota } \\ \text { Amostra } & \text { Nota } \\ \text { Amostra } & \text { Nota }\end{array}$

e) fruta fresca

$\begin{array}{ll}\text { Amostra } & \text { Nota } \\ \text { Amostra } & \text { Nota } \\ \text { Amostra } & \text { Nota } \\ \text { Amostra } & \text { Nota } \\ \text { Nota } & \text { Nota } \\ \text { Amostra } & \\ \text { amargo } & \text { Nota } \\ \text { Amostra } & \text { Nota } \\ \text { Amostra } & \text { Nota } \\ \text { Amostra } & \text { Nota } \\ \text { Amostra } & \text { Nota } \\ \text { Amostra } & \end{array}$

b) doce

Amostra
Amostra
Amostra
Amostra $\square$ Nota
Amostra
Nota
Nota
Nota

d) ácido

$\begin{array}{ll}\text { Amostra } & \text { Nota } \\ \text { Amostra } & \text { Nota } \\ \text { Amostra } & \text { Nota } \\ \text { Amostra } & \text { Nota } \\ \text { Amostra } & \text { Nota }\end{array}$

Qual?

Qual?

Qual?

Qual?

Qual?

Comentários gerais sobre sabor:

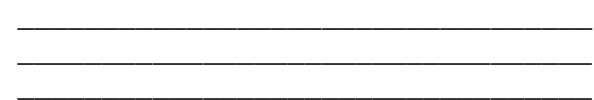

\section{TEXTURA}

a) característica de maçã

$\begin{array}{ll}\text { Amostra } & \text { Nota } \\ \text { Amostra } & \text { Nota } \\ \text { Amostra } & \text { Nota } \\ \text { Amostra } & \text { Nota } \\ \text { Amostra } & \text { Nota }\end{array}$

c) umidade

Amostra

Amostra

Amostra

Amostra

Amostra
Nota

Nota

Nota

Nota

Nota b) maciez

$\begin{array}{ll}\text { Amostra } & \text { Nota } \\ \text { Amostra } & \text { Nota } \\ \text { Amostra } & \text { Nota } \\ \text { Amostra } & \text { Nota } \\ \text { Amostra } & \text { Nota }\end{array}$

Qual?

Qual?

Qual?

Qual?

Qual?

Comentários gerais sobre textura:

Figura 9 - Ficha da análise descritiva quantitativa das maçãs MP (continuação) 
Para a realização da ADQ final, os provadores realizaram a análise sensorial nos dias 1, 5, 9 e 13 após armazenamento refrigerado das maçãs MP. Foram consideradas apenas a nota de 8 provadores para a análise estatística devido um provador não ter comparecido em todas as análises no período e o outro provador durante o treinamento não conseguiu seguir os parâmetros adotados para os atributos. As amostras não foram rejeitadas em nenhum momento durante todo o experimento.

\subsubsection{Análise estatística}

O delineamento experimental utilizado foi o inteiramente aleatorizado em esquema fatorial $5 \times 4$, sendo 5 tratamentos (controle, solução conservadora, dextrina, fécula de mandioca e alginato de sódio) e 4 períodos de avaliação (1, 5, 9 e 13 dias de armazenamento refrigerado). Nas análises físicas e físicoquímicas realizadas foram utilizadas 9 repetições em cada tratamento, exceto para cor que foram utilizadas 5 repetições.

Os resultados obtidos das avaliações físicas, físico-químicas e sensoriais foram submetidos à análise de variância pelo Teste $F$, comparação de médias pelo Teste de Tukey (5\%) e regressão linear, utilizando-se o sistema estatístico SAS (Statistical Analysis System, 1989). 


\section{RESULTADOS E DISCUSSÃO}

\subsection{Aspecto geral das maçãs MP}

O aspecto geral das maçãs MP obtidas no $1^{\circ}$ e $13^{\circ}$ dia após processamento pode ser avaliado, respectivamente pelas Figuras 10 e 11.

No primeiro dia após o processamento, o aspecto das amostras que é mais evidente é o escurecimento das maçãs MP do tratamento controle. Este fato mostra que é nas primeiras horas após o corte que ocorrem as reações oxidativas nas maçãs e que os demais tratamentos mostrara, certo controle das mesmas.

No $13^{\circ}$ dia foi verificado escurecimento em todos os tratamentos. 


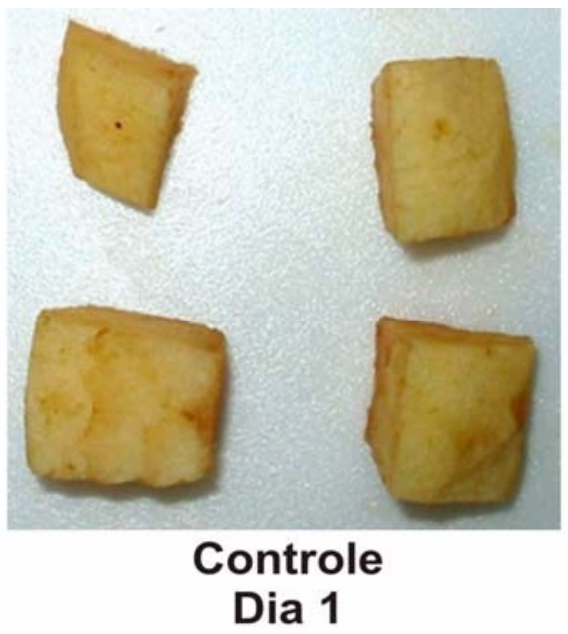

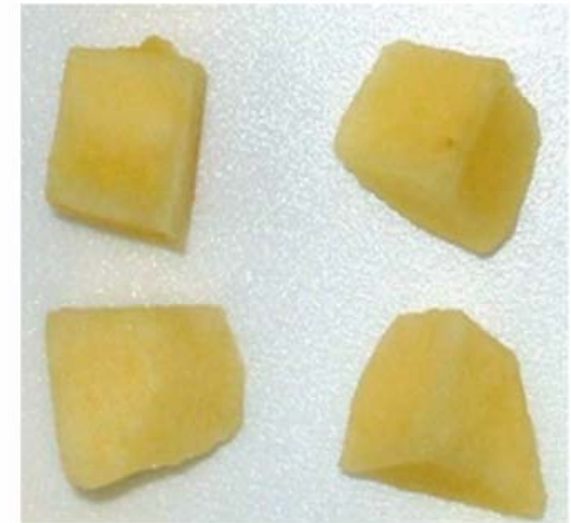

Solução conservadora

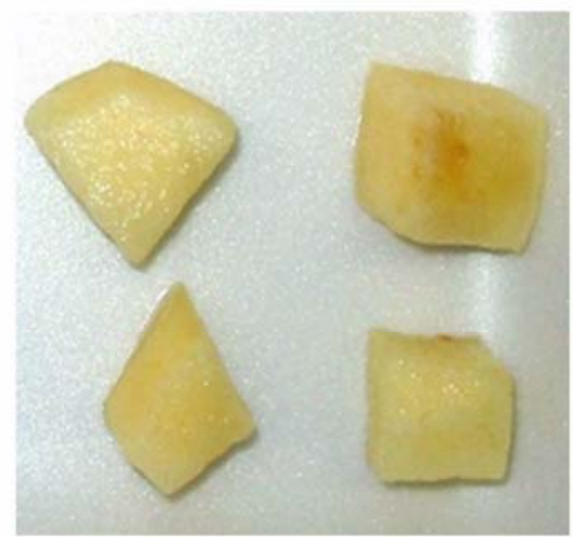

Fécula de mandioca

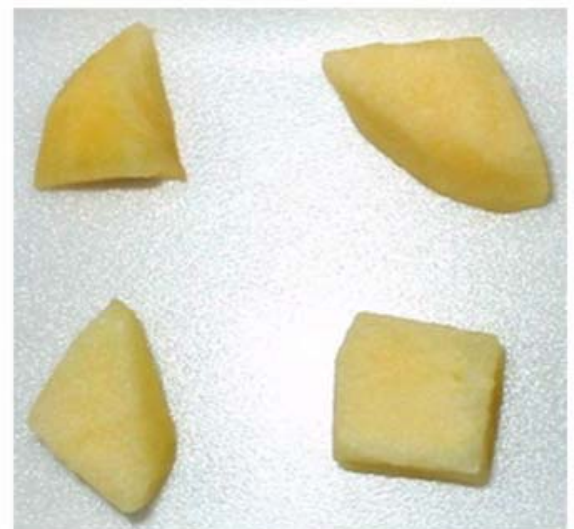

Dextrina

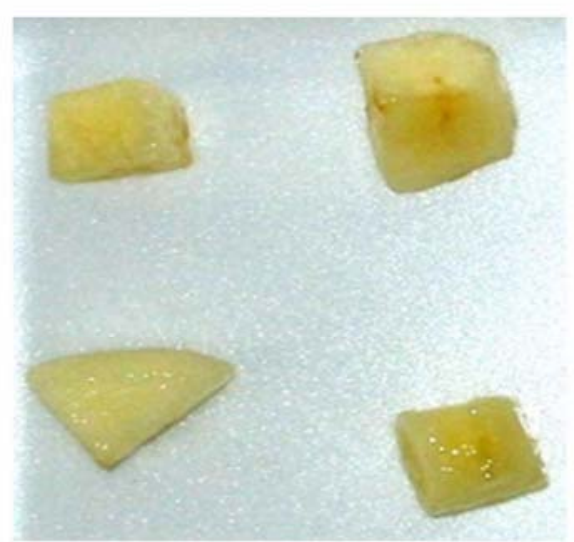

Alginato

Figura 10 - Aspecto das maçãs MP no $1^{\circ}$ dia de armazenamento refrigerado 


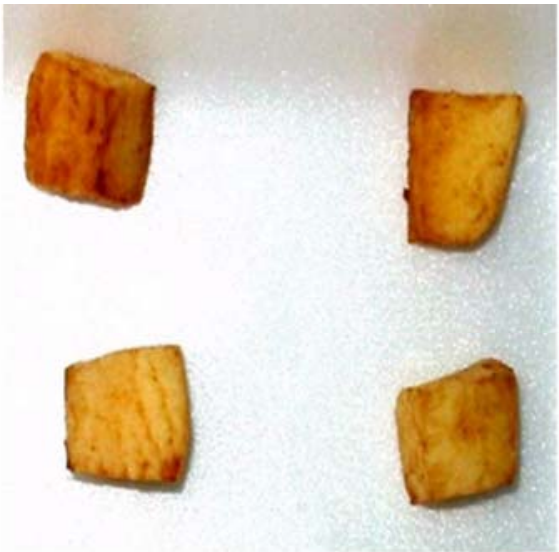

Controle

Dia 13

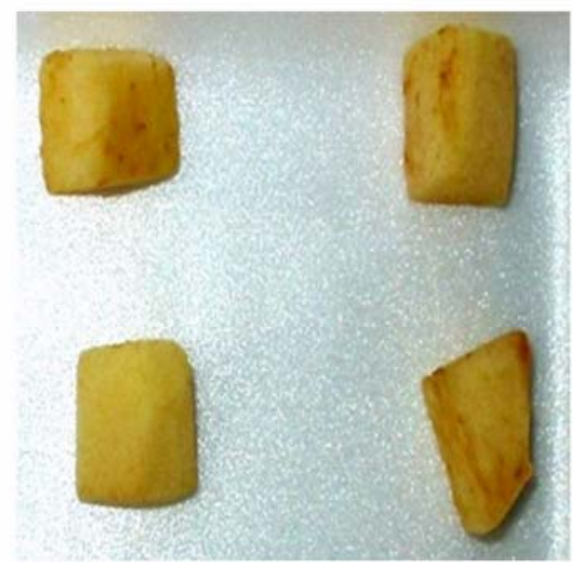

Solução conservadora

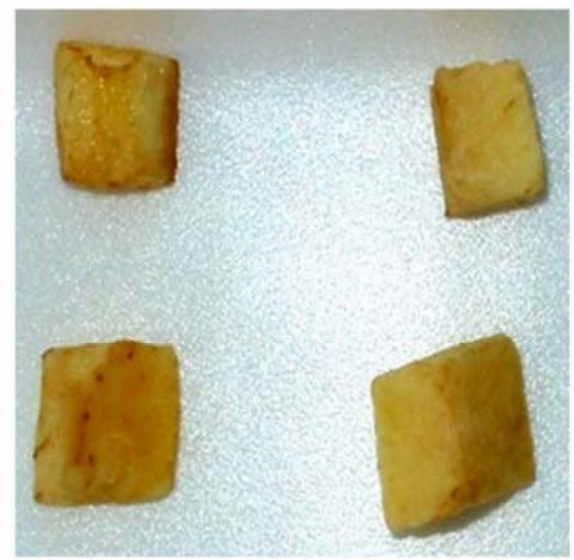

Fécula de mandioca
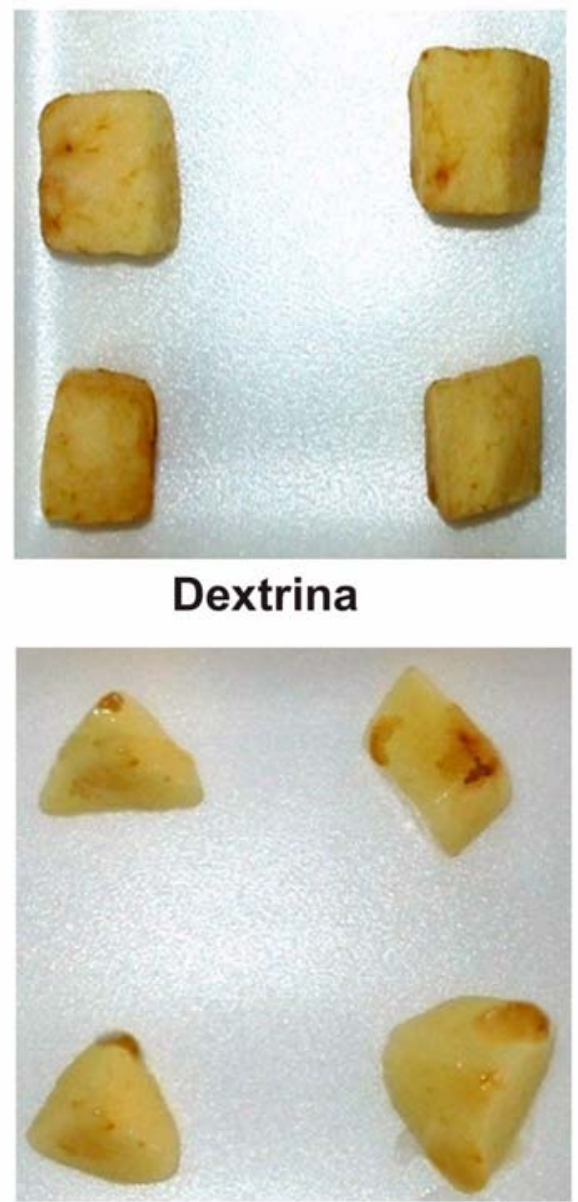

Alginato

Figura 11 - Aspecto das maçãs MP no $13^{\circ}$ dia de armazenamento refrigerado 


\subsection{Aspecto superficial das maçãs}

Fotos da superfície das películas de dextrina, fécula de mandioca e alginato sobre as maçãs MP foram obtidas por microscopia eletrônica de varredura e são apresentadas respectivamente nas Figuras 12, 13 e 14.

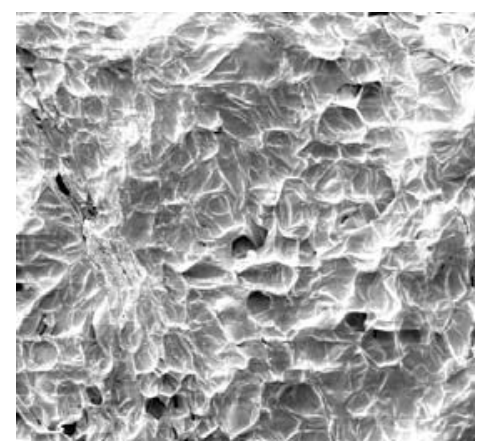

(a)

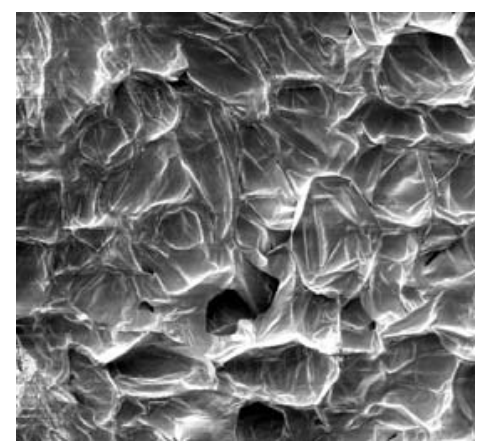

(b)

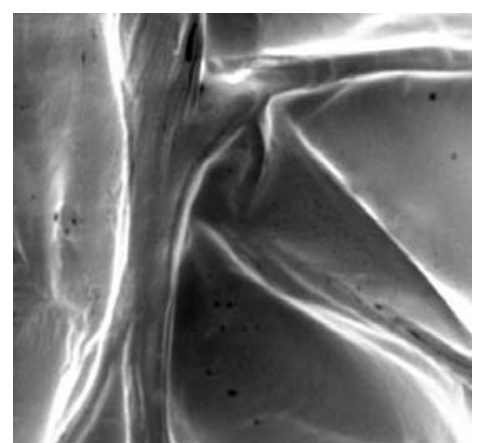

(c)

Figura 12 - Micrografias das superfícies de maçãs MP que receberam tratamento de dextrina de fécula de mandioca, sob aumento de (a) 50x, (b) 100x, (c) $1000 x$

A camada de revestimento formada pela dextrina de fécula de mandioca sobre o tecido vegetal cortado parece ser muito fina. A superfície apresenta certa rugosidade, que em um aumento maior lembra os componentes histológicos do vegetal. Apresenta também cavidades ou poros que, possivelmente, sejam decorrentes da formação de microbolhas de ar. Tais orifícios poderiam aumentar a permeabilidade da superfície ao vapor de água e aos gases ocasionando, provavelmente, a perda de umidade e o escurecimento. 


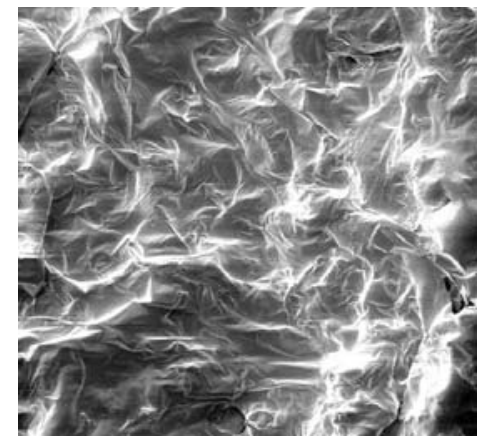

(a)

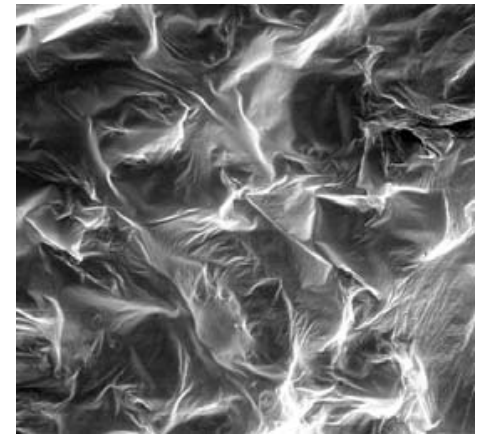

(b)

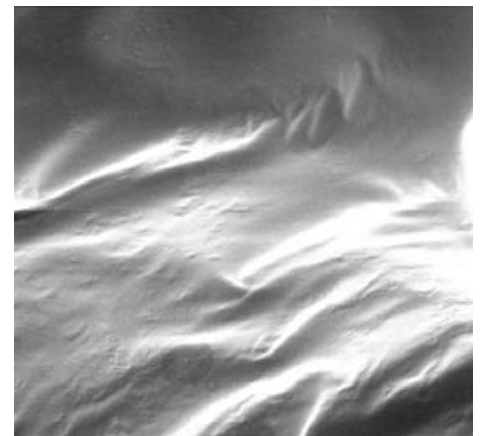

(c)

Figura 13 - Micrografias das superfícies de maçãs MP que receberam tratamento de fécula de mandioca, sob aumento de (a) 50x, (b) 100x, (c) 1000x

A película de fécula de mandioca sobre as maçãs MP se mostrou mais espessa, menos rugosa e com menor quantidade de poros se comparada com a camada formada pela dextrina.

Trabalho realizado por Cereda et al. (2000) evidenciou uma superfície contínua com presença de poros em filmes de fécula de mandioca natural modificada a $3 \%$.

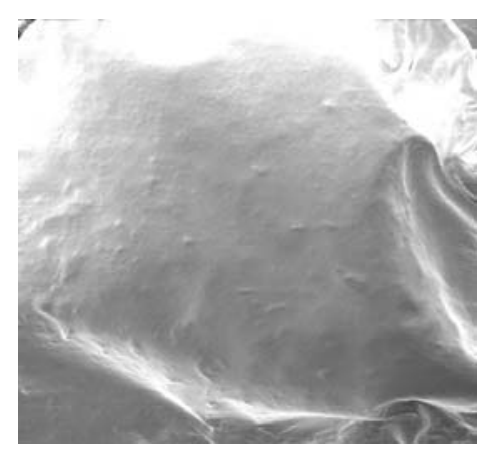

(a)

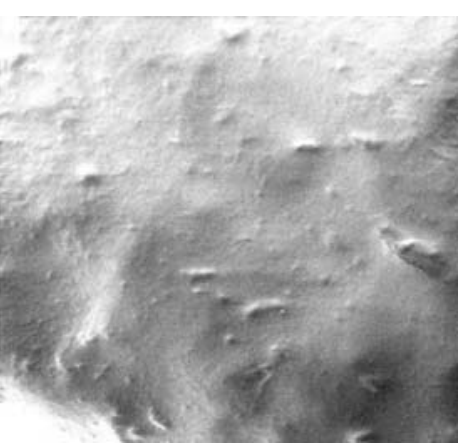

(b)

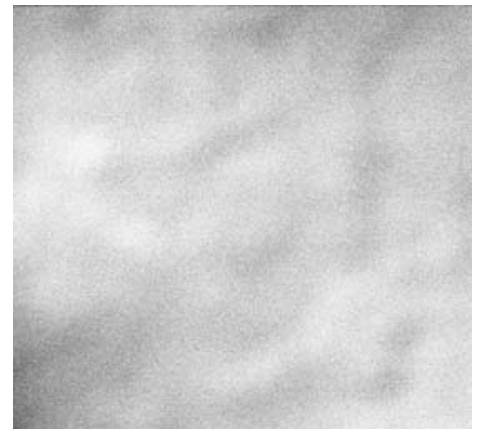

(c)

Figura 14 - Micrografias das superfícies de maçãs MP que receberam tratamento de alginato sob aumento de (a) 50x, (b) 100x, (c) 1000x

A película formada pelo alginato de sódio e cálcio apresentou superfície de aspecto mais homogêneo, sem poros ou rachaduras, com estruturas 
compactas, o que é indicativo da sua integridade estrutural. A continuidade da superfície evidencia a maior espessura dessa película.

\subsection{Fisiologia}

\subsubsection{Taxa respiratória}

Os teores de $\mathrm{CO}_{2}$ liberados pelas amostras de cada tratamento durante o período de armazenamento refrigerado (Figura 15) apresentaram perfil com um pico respiratório que ocorreu no $2^{\circ}$ dia após o processamento para todas as maçã MP. Este pico, provavelmente, seja reflexo do estresse provocado pelo descascamento e corte do tecido.

Purvis (1997) cita estudos que mostram picos na taxa respiratória de vegetais MP com redução subseqüente, ainda não bem explicados. O autor sugere que haja uma auto-regulação da atividade respiratória do tecido devido à grande produção de ATP, ou que esta redução ocorra pelo fato dos substratos respiratórios reagirem menos com as enzimas presentes nas células da superfície de corte. Com isso, a taxa respiratória observada a partir do pico pode ser resultado das células localizadas abaixo da superfície injuriada do corte.

Segundo Chitarra (2000) a operação do corte causa perda da compartimentação celular e, com isto, os substratos do metabolismo respiratório entram em contato com os complexos enzimáticos, resultando em incremento da taxa respiratória. Outra hipótese pode ser a resposta lenta das maçãs MP, que corresponde a reações biossintéticas, com formação de barreiras estruturais. Iniciam-se após uma ou várias horas e são respostas compartimentadas, ou seja, em nível de membranas, citosol ou paredes celulares. Embora inicialmente ocorra um "caos" celular, um padrão de resposta predizível e coordenada culmina com o fechamento do ferimento ao longo do tempo, usualmente após 3 a 4 dias do ferimento do tecido vegetal. 


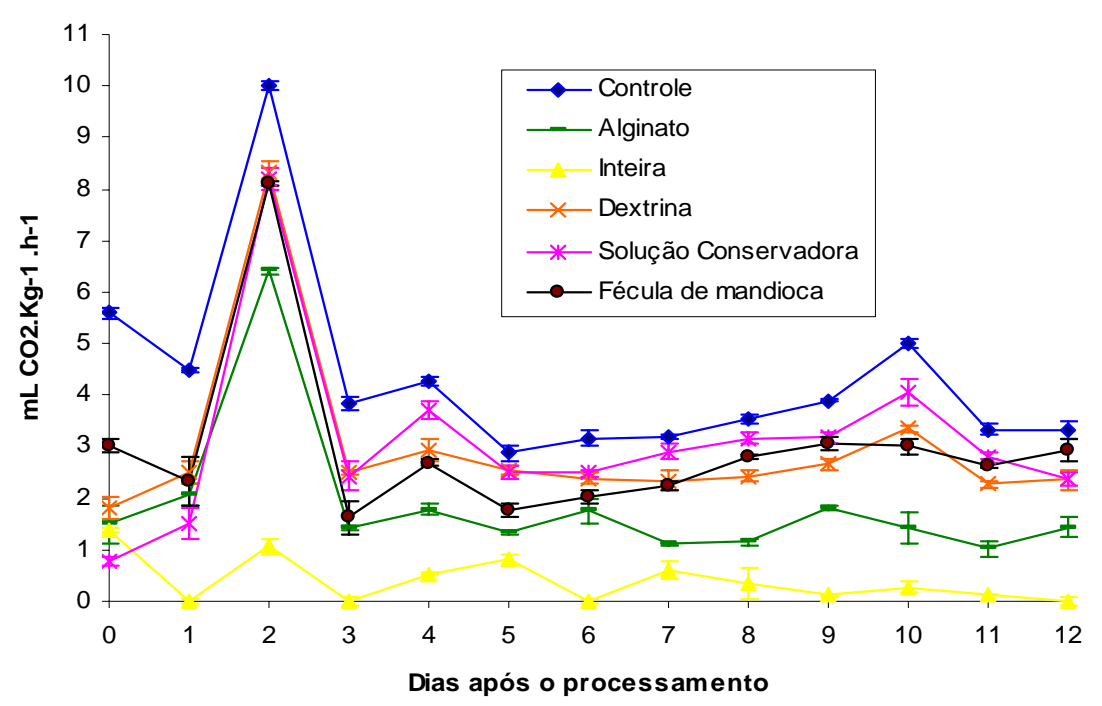

Barras verticais representam o erro padrão da média

Figura 15 - Taxa respiratória de maçãs MP sob diferentes tratamentos armazenadas a $2^{\circ} \mathrm{C}$

A média dos valores de $\mathrm{CO}_{2}$ produzidos pelas amostras durante $\mathrm{o}$ armazenamento, desconsiderando o pico ( $\left.2^{\circ} \mathrm{dia}\right)$, foi utilizada para efeitos de comparação entre os tratamentos.

As maçãs MP apresentam valores médios entre 1,48 e 3,88 mL $\mathrm{CO}_{2} \cdot \mathrm{kg}^{-1} \cdot \mathrm{h}^{-1}$ (Figura 15), consideravelmente mais elevados que o das maçãs inteiras $\left(0,34 \mathrm{~mL} \mathrm{CO} 2 \cdot \mathrm{kg}^{-1} \cdot \mathrm{h}^{-1}\right)$. Esta resposta já era esperada em função da ativação de reações fisiológicas e bioquímicas devido à injúria dos tecidos.

O tratamento com película de alginato de sódio foi o mais eficiente dentre os tratamentos no controle da taxa respiratória das maçãs MP, apresentando média de $1,48 \mathrm{~mL} \mathrm{CO} \cdot \mathrm{kg}^{-1} \cdot \mathrm{h}^{-1}$. Este fato evidencia uma maior eficiência dessa película quanto ao controle das trocas gasosas, possivelmente em função de sua natureza, espessura ou formação de superfície contínua e sem bolhas. A cobertura de fécula de mandioca apresentou a maior taxa respiratória dentre os tratamentos com película. Este polímero gera película não 
eficiente para este fim, possivelmente com microbolhas de ar, que possibilitam trocas gasosas.

As maçãs MP tratadas com solução conservadora apresentaram média de 2,66 mL $\mathrm{CO}_{2} \cdot \mathrm{kg}^{-1} \mathrm{~h}^{-1}$, inferior às apresentadas pelas maçãs MP controle $\left(3,88 \mathrm{~mL} \mathrm{CO} 2 \cdot \mathrm{kg}^{-1} \cdot \mathrm{h}^{-1}\right)$. Estudando cenouras MP, Kato-Noguchi \& Watada (1997), entretanto, observaram que a taxa respiratória foi substancialmente reduzida com a aplicação do ácido cítrico. O ácido cítrico está envolvido na inibição da enzima fosfofrutoquinase que catalisa a fosforilação da frutose 6fosfato em 1,6-bifosfato na via glicolítica do metabolismo respiratório.

As maçãs MP revestidas por películas apresentaram taxas respiratórias que foram, em média, 1,6 vezes menor que o tratamento controle. Estudando goiabas var. Kumagai armazenadas em condições ambientes (19,5-27 $\mathrm{C}$ e $59-76 \%$ UR) Oliveira (1996), observou que tanto os frutos tratados com cera "sta:fresh" (1:1) quantos os tratados com películas de fécula de mandioca a 1 e 2\%, apresentaram menor taxa respiratória que as dos frutos testemunha.

Kester \& Fennema (1986) aplicaram revestimento de éster de sacarosecarboximetilcelulose (CMC) em frutos inteiros de bananas verdes e também verificaram redução da permeabilidade ao oxigênio em 5 vezes, e da permeabilidade ao dióxido de carbono em menos de 2 vezes, quando comparados com bananas não revestidas.

\subsubsection{Etileno}

As taxas de produção de etileno pelas maçãs MP durante o período experimental (Figura 16) mostram que no dia do processamento o corte dos tecidos alterou consideravelmente as taxas de liberação de etileno. 


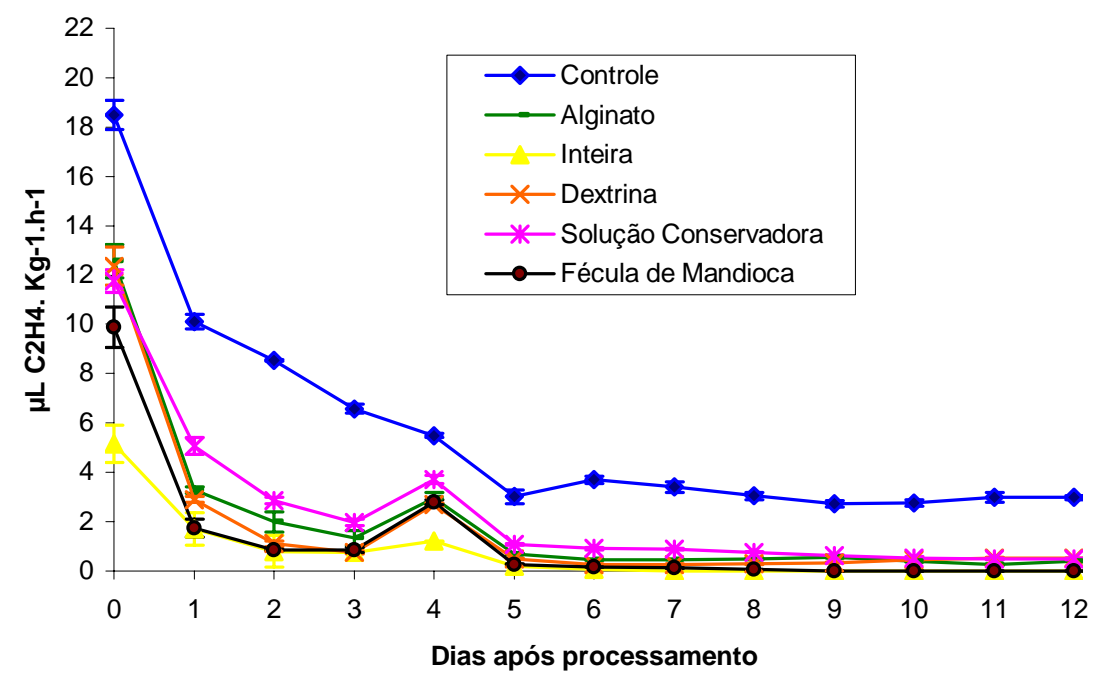

Barras verticais representam o erro padrão da média

Figura 16 - Produção de etileno pelas maçãs MP por diferentes tratamentos durante o armazenamento

No $1^{\circ}$ dia de armazenamento foi observado um maior percentual de queda na produção deste gás pelas maçãs, até mesmo para o fruto inteiro. Com o armazenamento a redução na produção de etileno tendeu, no geral, a ocorrer em níveis menores até haver certa estabilização de valores ao final do experimento.

Para efeitos de comparação foi utilizada a média dos valores observados durante o armazenamento das amostras de cada tratamento, desconsiderando o pico do dia do processamento. Os tratamentos que apresentaram maiores taxas de produção de etileno, também apresentaram as maiores taxas respiratórias.

As maçãs MP dos tratamentos estudados apresentaram médias de produção de etileno variando de 0,88 a $4,61 \mu \mathrm{L} \mathrm{C}_{2} \mathrm{H}_{4} \cdot \mathrm{Kg}^{-1} \cdot \mathrm{h}^{-1}$, mais elevados que o da maçã inteira $\left(0,39 \mu \mathrm{L} \mathrm{C}_{2} \mathrm{H}_{4} \cdot \mathrm{Kg}^{-1} \cdot \mathrm{h}^{-1}\right)$. Segundo Brecht (1995) esses danos mecânicos advindos do processamento mínimo aumentam o metabolismo, com conseqüente aumento da síntese de etileno, causando maior velocidade de 
deterioração. O etileno proveniente do corte ("etileno de ferimento") contribui para a biossíntese de enzimas envolvidas em alterações fisiológicas e bioquímicas associadas à senescência.

A taxa de produção de etileno do tratamento controle apresentou valor médio de 4,61 $\mu \mathrm{L} \mathrm{C}_{2} \mathrm{H}_{4} \cdot \mathrm{kg}^{-1} \cdot \mathrm{h}^{-1}$, superior ao da maçã MP imersa em solução conservadora que foi de $1,62 \mu \mathrm{L} \mathrm{C}_{2} \mathrm{H}_{4} \cdot \mathrm{kg}^{-1} \cdot \mathrm{h}^{-1}$. Tanto o tratamento com solução conservadora, como os de cobertura (fécula de mandioca $=0,57 \mu \mathrm{L} \quad \mathrm{C}_{2} \mathrm{H}_{4}$ $\mathrm{kg}^{-1} \cdot \mathrm{h}^{-1}$; dextrina $=0,88 \mu \mathrm{L} \quad \mathrm{C}_{2} \mathrm{H}_{4} \cdot \mathrm{kg}^{-1} \cdot \mathrm{h}^{-1}$ e alginato $=1,10 \mu \mathrm{L} \quad \mathrm{C}_{2} \mathrm{H}_{4} \cdot \mathrm{kg}^{-1} \cdot \mathrm{h}^{-1}$ ) reduziram a produção de etileno em mais de $50 \%$ em relação ao tratamento controle. Este comportamento evidencia a importância da solução conservadora no armazenamento de produtos MP, destacando-se o papel do ácido cítrico atuando no metabolismo vegetal e do cálcio, que atuam, segundo Peroni (2002) possivelmente, como um enrijecedor do tecido superficial.

\subsection{Físicas e físico-químicas das maçãs MP}

\subsubsection{Umidade}

A umidade de um fruto pode ser definida como a quantidade de água presente no vegetal na sua totalidade, em suas diferentes formas (livre e ligada). A perda de água dos frutos relaciona-se principalmente ao processo de transpiração, respiração e ao tempo de armazenamento e resulta em enrugamento, amolecimento dos tecidos e perda de brilho, tornando os frutos mais susceptíveis às deteriorações. Também pode ocasionar alterações na cor e sabor dos mesmos (Kader, 1992).

Os teores de umidade das maçãs MP obtidas por diferentes tratamentos e armazenadas por diferentes tempos são apresentados na Tabela 1. 
Tabela 1. Porcentagem de umidade das maçãs MP em função dos tratamentos e do tempo de armazenamento

\begin{tabular}{lcccc}
\hline \multicolumn{5}{c}{ Tempo de armazenamento (dias) } \\
\hline Tratamentos & 1 & 5 & 9 & 13 \\
\hline Controle & 85,32 b A & 85,26 b A & 84,98 a A & 84,88 a A \\
Solução conservadora & 85,87 b A & 85,88 b A & 85,65 a A & 85,40 a A \\
Fécula de mandioca & 87,76 ab A & 87,02 b A & 86,81 a A & 86,52 a A \\
Dextrina de mandioca & 87,24 b A & 87,26 ab A & 86,41 a A & 86,21 a A \\
Alginato de sódio & 89,38 a A & 89,36 a A & 84,97 a B & 84,86 a B \\
\hline
\end{tabular}

Médias seguidas de mesma letra minúscula na coluna e maiúscula na linha não diferem entre si, pelo Teste de Tukey em nível de $5 \%$ de probabilidade.

Os teores de umidade das maçãs MP variaram entre os tratamentos dentro do $1^{\circ}$ e do $5^{\circ}$ dia de armazenamento, após isto tenderam a se igualar. Dentre os tratamentos o com alginato tendeu a apresentar amostras mais úmidas no início do armazenamento. No $9^{\circ}$ e $13^{\circ}$ dia não foi constatada diferença entre os tratamentos. No início do armazenamento, o teor de umidade dos tratamentos com coberturas, geralmente mais elevados, pode indicar que o revestimento dos tecidos estaria evitando a perda de umidade mais acentuada do momento do processamento para o $1^{\circ}$ dia de armazenamento nas amostras sem revestimentos. Outra hipótese seria o fato de que as películas podem reter em si, parte da umidade existente no interior das embalagens de produtos MP, pois são hidrofílicos.

Considerando o período de armazenamento estudado, as maçãs MP não apresentaram perdas significativas de umidade no tempo, exceto as tratadas com alginato, que do $1^{\circ}$ ao $9^{\circ}$ dia evidenciaram perdas que atingiram $5 \%$. Os teores de umidade dessas amostras do $9^{\circ}$ e $13^{\circ}$ dia são semelhantes aos demais tratamentos nesses mesmos períodos. Há que se considerar também que esta perda de umidade pode ser originada da desidratação da própria película ao longo do armazenamento. 
Pela análise de regressão apenas as maçãs MP revestidas de fécula de mandioca apresentaram equação linear significativa para variação do teor de umidade em função do tempo (Figura 17).

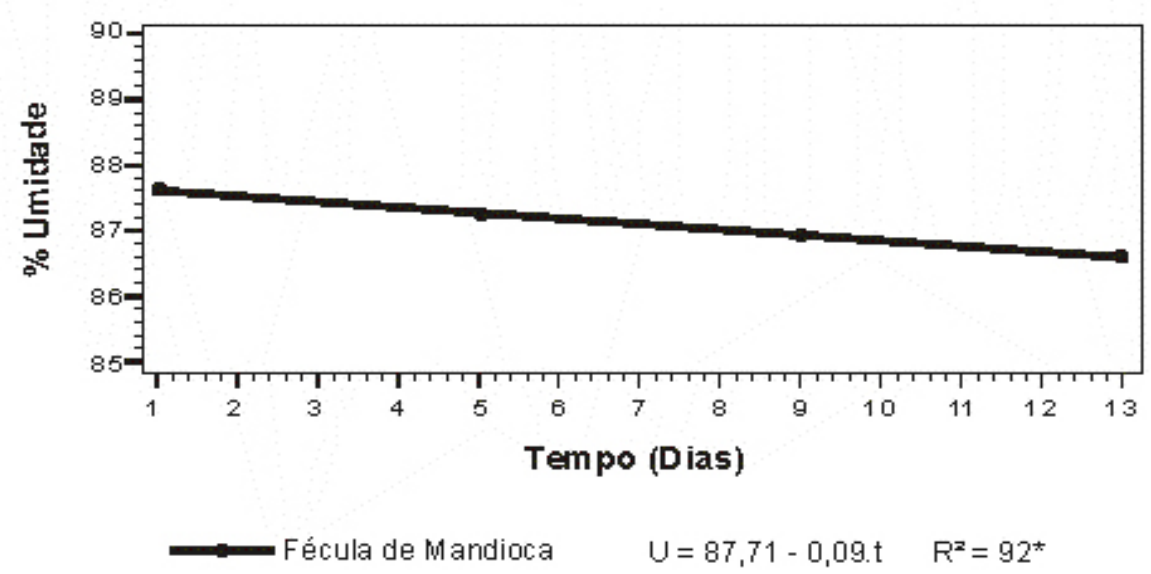

Figura 17 - Representação gráfica e equação linear de umidade das maçãs MP revestidas de fécula de mandioca durante o armazenamento

Embora os teores de umidade das maçãs recobertas com alginato tenham diferido significativamente no tempo de armazenamento, pelo teste de Tukey, esta variação não foi linear.

Coberturas de alginato constituem excelente barreira contra as trocas de gases, mas não evitam a perda de umidade do produto para o meio, pois são revestimentos hidrofílicos (Maia et al., 2000). Esta perda de umidade poderia ser melhor controlada, possivelmente, pela incorporação de aditivos hidrofóbicos.

Estudo realizado por Vieira et al. (2000) mostrou que abacaxis minimamente processados recobertos com película de fécula de mandioca a 3\% apresentaram maior perda de água que a testemunha, após 1 semana sob armazenamento refrigerado. 


\subsubsection{Textura}

A textura é um dos principais atributos de qualidade em frutos e as propriedades mecânicas de resistência dos tecidos se correlacionam com as características estruturais do conglomerado celular e estas são dependentes da coesividade, do tamanho, da forma e da turgidez das células que compõem o tecido (Awad,1993).

Com o avanço da maturação dos frutos durante o armazenamento e a chegada da senescência, espera-se um decréscimo nos valores de textura. Durante a maturação ocorre a conversão da pectina insolúvel em pectina solúvel, amolecendo e diminuindo a resistência dos frutos.

A dureza das maçãs MP (Tabela 2) apresentaram diferenças quanto à dureza entre os tratamentos dentro de cada tempo de armazenamento e entre os tempos de armazenamento dentro de cada tratamento.

Tabela 2. Dureza (lbf/g) das maçãs MP em função dos tratamentos e do tempo de armazenamento

\begin{tabular}{lcccc}
\hline & \multicolumn{4}{c}{ Tempo de armazenamento (dias) } \\
\hline Tratamentos & 1 & 5 & 9 & 13 \\
\hline Controle & 3,62 a A & 2,99 a AB & 2,87 b B & 2,53 b B \\
Solução conservadora & 3,17 a B & 3,67 a AB & 4,17 a A & 4,48 a A \\
Fécula de mandioca & 1,83 b B & 2,31 b AB & 2,56 b A & 2,88 b A \\
Dextrina de mandioca & 2,01 b B & 2,31 b B & 2,58 b AB & 2,90 b A \\
Alginato de sódio & 2,11 b B & 2,36 b AB & 2,59 b A & 2,60 b A \\
\hline
\end{tabular}

Médias seguidas de mesma letra minúscula na coluna e maiúscula na linha não diferem entre si, pelo Teste de Tukey em nível de 5\% de probabilidade.

As maçãs MP imersas apenas em solução conservadora tenderam a apresentar maior firmeza que as maçãs dos demais tratamentos dentro de cada tempo de armazenamento. Tal fato, possivelmente seja justificado pela presença na solução conservadora do $\mathrm{CaCl}_{2}(0,25 \%)$, que pode promover o enrijecimento do tecido superficial. Embora os tratamentos com películas 
também tenham recebido esta solução, a imersão posterior, com as substâncias formadoras de revestimento pode ter diluído o efeito do cálcio, gerando menores valores de dureza.

O cálcio participa de maneira efetiva na manutenção da firmeza do fruto, devido à sua função de ligação com pectinas ácidas da parede celular e da lamela média. A presença do cálcio além de conferir insolubilidade ao material péctico, inibe a degradação pela poligalacturonase, principal enzima responsável pelo amaciamento dos frutos, uma vez que o pectato de cálcio formado é resistente à degradação por esta enzima (Awad,1993).

O uso de cloreto de cálcio em diferentes concentrações $(0,3 \% ; 0,6 \%$; $0,9 \% ; 1,2 \%)$ em melão minimamente processado foi eficiente para manutenção da dureza do fruto e o aumento na concentração de cálcio não demonstrou um maior efeito na firmeza no fruto (Peroni, 2002).

No tratamento controle foi verificada redução dos valores de dureza ou amolecimento com o armazenamento, tendência natural do tecido vegetal no tempo. Nos demais tratamentos que receberam adição de cálcio, a tendência foi oposta ao controle. No caso das maçãs MP com revestimentos, a tendência ao enrijecimento das mesmas pode estar sendo gerada pela tendência das macromoléculas, principalmente a dextrina e fécula de mandioca à retrogradação.

A análise de regressão linear (Figura 18) confirmou os testes de média mostrando que os valores de dureza nas maçãs MP controle são inversamente proporcionais ao tempo de armazenamento e nos demais tratamentos são diretamente proporcionais. 


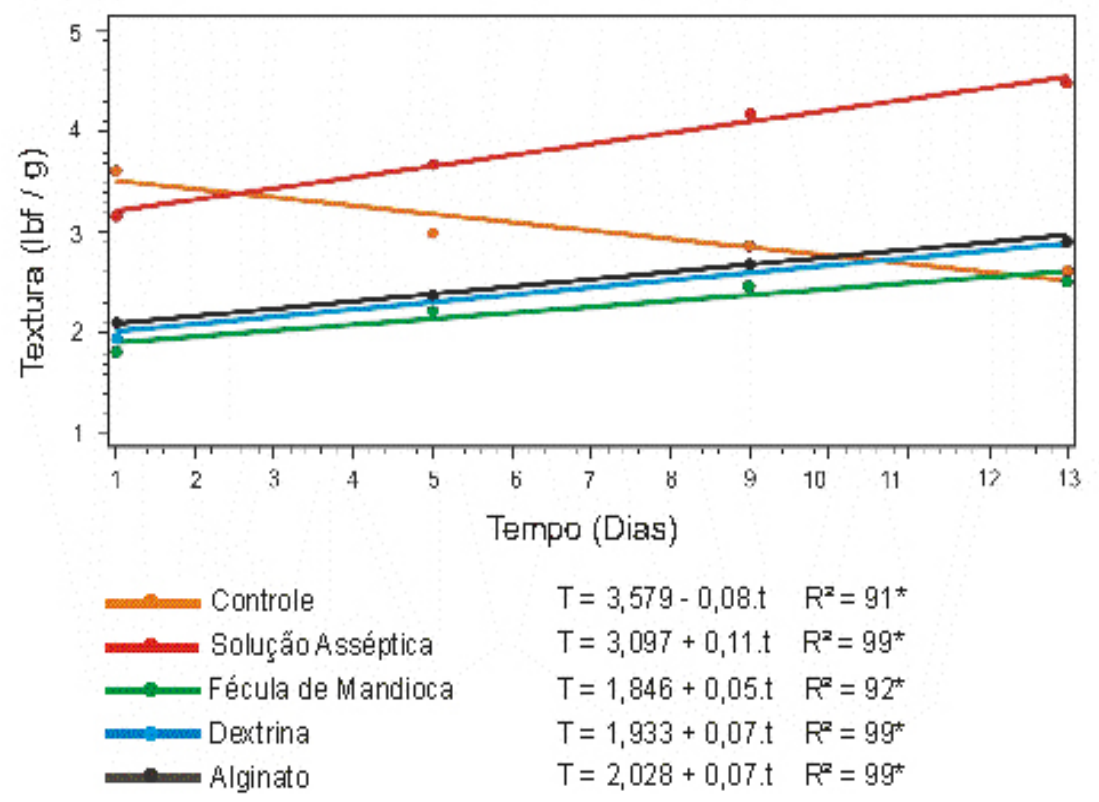

Figura 18 - Tendência de variação da dureza das maçãs MP por diferentes tratamentos durante o armazenamento

\subsubsection{Teor de sólidos solúveis totais}

Os sólidos solúveis totais (SST) são compostos solúveis em água e importantes na determinação da qualidade da fruta (Kluge, 2002). Segundo Fan (1992) pode ocorrer uma queda no teor de SST durante o armazenamento, a qual se justifica pelo consumo dos substratos no metabolismo respiratório das frutas.

O teor de SST das maçãs MP (Tabela 3) apresentou variação significativa entre os tratamentos dentro de cada tempo de armazenamento e para cada tratamento durante o armazenamento. 
Tabela 3. Sólidos solúveis totais ( ${ }^{\circ}$ Brix) das maçãs MP em função dos tratamentos e do tempo de armazenamento

\begin{tabular}{lcccc}
\hline & \multicolumn{4}{c}{ Tempo de armazenamento (dias) } \\
\hline Tratamentos & 1 & 5 & 9 & 13 \\
\hline Controle & 13,2 a B & 14,6 a B & 13,2 a B & 16,6 a A \\
Solução conservadora & 12,5 ab A & 13,6 ab A & 13,8 a A & 13,8 b A \\
Fécula de mandioca & 10,3 c B & 11,6 c A & 11,2 b AB & 12,1 c A \\
Dextrina de mandioca & 11,2 bc B & 12,6 bc A & 11,9 b AB & 12,6 bc A \\
Alginato de sódio & 13,0 ab B & 14,5 a B & 13,3 a B & 16,4 a A
\end{tabular}

Médias seguidas de mesma letra minúscula na coluna e maiúscula na linha não diferem entre si, pelo Teste deTukey em nível de 5\% de probabilidade.

A maior concentração de sólidos solúveis é apresentada pelas maçãs do tratamento controle, embora esta não tenha diferido estatisticamente da maçã com solução conservadora e da revestida com alginato. As alterações entre os tratamentos se tornaram mais acentuadas ao final do armazenamento (13 dia), principalmente para as maçãs do grupo controle e para as tratadas com alginato. A perda de umidade ocorrida nas maçãs tratadas com alginato ao final do armazenamento pode ter ocasionado uma maior concentração dos teores de sólidos solúveis. Esta consideração, entretanto, não explica o comportamento do tratamento controle.

Os tratamentos com fécula de mandioca e dextrina resultaram em maçãs com menores teores de sólidos solúveis durante todo o período avaliado. A imersão das maçãs MP nestes tipos de solução filmogênicas poderia estar lixiviando os sólidos solúveis do vegetal.

De acordo com Lima (1999) maçãs inteiras da cv. Royal Gala armazenadas sob refrigeração, ao final do primeiro mês, apresentaram valores de teor de sólidos solúveis totais em torno de $10^{\circ}$ Brix, acidez total titulável próximos de 0,33\% de ácido málico, pH 4 e firmeza de 84,35 Newtons.

O tempo de armazenamento alterou significativamente o teor de SST das maçãs MP, exceto para as tratadas apenas com solução conservadora. A 
análise de regressão linear não apresentou equações lineares, em nível de 5\%, pois a tendência não foi definida no tempo para os tratamentos.

\subsection{4 pH}

A acidez constitui fator de grande importância para o sabor e aroma dos frutos e, além disso, o pH influencia o escurecimento oxidativo dos tecidos vegetais. A diminuição do seu valor acarreta redução da velocidade de escurecimento do fruto (Braverman,1967).

Os valores de pH das maçãs MP (Tabela 4) diferiram significativamente entre os tratamentos dentro de cada tempo de armazenamento e com o tempo de armazenamento.

Tabela 4. Valores de pH das maçãs MP em função dos tratamentos e do tempo de armazenamento

\begin{tabular}{lcccc}
\hline & \multicolumn{4}{c}{ Tempo de armazenamento (dias) } \\
\hline Tratamentos & 1 & 5 & 9 & 13 \\
\hline Controle & 3,73 b A & 3,70 b A & 3,78 b AB & 3,88 c B \\
Solução conservadora & 3,54 a A & 3,53 a A & 3,53 a A & 3,56 a A \\
Fécula de mandioca & 3,76 b A & 3,77 b A & 3,71 b A & 3,75 b A \\
Dextrina de mandioca & 3,73 b AB & 3,69 b A & 3,75 b AB & 3,83 b B \\
Alginato de sódio & 4,13 c A & 3,99 c A & 4,08 c A & 4,01 c A
\end{tabular}

Médias seguidas de mesma letra minúscula na coluna e maiúscula na linha não diferem entre si, pelo Teste de Tukey em nível de 5\% de probabilidade.

As maçãs MP tratadas com solução conservadora apresentaram valores de $\mathrm{pH}$ mais baixos em todos os dias avaliados, possivelmente devido aos componentes da solução utilizada (ácido ascórbico e ácido cítrico), que resultaram em pH da solução de 2,2.

Os valores de $\mathrm{pH}$ das maçãs MP que receberam imersão em solução conservadora e posteriormente em substâncias formadora de películas apresentaram valores de $\mathrm{pH}$ superiores, provavelmente em decorrência da 
interferência do pH das soluções filmogênicas. $\mathrm{O}$ pH da solução de alginato foi igual a 7.

Moreira (2004) estudou maçã minimamente processada submetida a tratamento com ácido ascórbico a 1\% e verificou um decréscimo no $\mathrm{pH}$ das frutas em relação à testemunha.

De acordo com Vieira et. al. (2000) os abacaxis minimamente processados com película de fécula de mandioca nas concentrações 1\%, 2\% e $3 \%$, sob armazenamento refrigerado a $5^{\circ} \mathrm{C}$, apresentaram valores mais elevados de $\mathrm{pH}$ que a testemunha.

Os tratamentos solução conservadora, fécula de mandioca e alginato conservaram o pH das frutas inalterado durante o armazenamento. Já maçãs dos tratamentos controle e dextrina apresentaram tendência a aumento de $\mathrm{pH}$.

A análise de regressão linear não apresentou tendência estatisticamente significativa, devido ao comportamento variado do $\mathrm{pH}$.

\subsubsection{Acidez total titulável}

O valor de $\mathrm{pH}$ de um produto expressa apenas o ácido dissociado e que tem o poder de tamponar a solução, enquanto que a acidez total titulável (ATT) expressa a quantidade de ácido presente.

A acidez das maçãs (Tabela 5) apresentou comportamento semelhante ao de $\mathrm{pH}$. As maçãs que receberam o tratamento com solução conservadora apresentaram os maiores valores de acidez e os menores teores de acidez detectados nos demais tratamentos justifica-se pelas mesmas razões já explicadas para o $\mathrm{pH}$. 
Tabela 5. Acidez das maçãs MP em função dos tratamentos e do tempo de armazenamento

\begin{tabular}{lcccc}
\hline & \multicolumn{4}{c}{ Tempo de armazenamento (dias) } \\
\hline Tratamentos & 1 & 5 & 9 & 13 \\
\hline Controle & 0,39 b A & 0,44 b A & 0,48 ab A & 0,45 b A \\
Solução conservadora & 0,54 a A & 0,56 a A & 0,52 a A & 0,55 a A \\
Fécula de mandioca & 0,32 bc B & 0,36 bc AB & 0,42 ab A & 0,44 ab A \\
Dextrina de mandioca & 0,28 c B & 0,36 bc AB & 0,39 b AB & 0,43 b A \\
Alginato de sódio & 0,26 c B & 0,29 c AB & 0,27 c B & 0,36 b A \\
\hline
\end{tabular}

Médias seguidas de mesma letra minúscula na coluna e maiúscula na linha não diferem entre si, pelo Teste de Tukey em nível de $5 \%$ de probabilidade.

Brackmann (1990) afirma que a manutenção de níveis mais elevados de acidez total titulável também pode ser conseqüência da redução da atividade respiratória, pois os ácidos são as substâncias mais prontamente disponíveis para obtenção de energia pela célula, pois fazem parte do ciclo de Krebs.

Durante o armazenamento de pêssegos inteiros, Oliveira (2000) não detectou variação significativa, entre a ATT dos frutos recobertos com fécula de mandioca por 12 dias. A manutenção da ATT, possivelmente seja pela tendência do revestimento a proporcionar menor atividade metabólica.

\subsubsection{Cor}

A cor das maçãs MP foi avaliadas em termos de $L, a^{*} e b^{*}$. A variável $L$ indica luminosidade, diferenciando cores claras de escuras. Seu valor varia de zero para cores escuras (preto) e 100 para cores claras (branco). Os valores de Luminosidade (L) das maçãs MP são apresentados na Tabela 6. 
Tabela 6. Luminosidade (L) das maçãs MP em função dos tratamentos e do tempo de armazenamento

\begin{tabular}{lcccc}
\hline & \multicolumn{4}{c}{ Tempo de armazenamento (dias) } \\
\hline Tratamentos & 1 & 5 & 9 & 13 \\
\hline Controle & 74,4 b AB & 75,2 a A & 71,3 bc AB & 69,5 c B \\
Solução conservadora & 80,6 a A & 76,6 a A & 79,8 a A & 81,0 a A \\
Fécula de mandioca & 75,0 b A & 72,8 a A & $75,0 b$ A & 75,2 b A \\
Dextrina de mandioca & 75,4 ab A & 74,9 a A & 73,9 b A & 74,9 bc A \\
Alginato de sódio & 68,7 c AB & 67,0 b B & 66,8 c B & 73,2 bc A \\
\hline
\end{tabular}

Médias seguidas de mesma letra minúscula na coluna e maiúscula na linha não diferem entre si, pelo Teste de Tukey em nível de $5 \%$ de probabilidade.

A solução conservadora apresentou maçãs MP com tendência a colorações mais clara ao longo do armazenamento. Este fato pode estar associado a presença de agentes antioxidantes e branqueadores presentes na solução e também ao menor $\mathrm{pH}$ da fruta que, acarreta um menor escurecimento da polpa.

Reis (2002) estudou banana prata minimamente processada tratada com diferentes soluções $1 \%$ de $\mathrm{CaCl}_{2}, 1 \%$ de ácido ascórbico e $1 \%$ de Lcisteína separadamente. A solução de $\mathrm{CaCl}_{2}$ diferenciou-se dos demais tratamentos químicos, apresentando maiores valores de $L \mathrm{e}$, portanto, menor escurecimento.

As polpas de maçãs MP com alginato apresentaram as menores médias de L (coloração mais escura) dentre os tratamentos, no entanto, tais valores não diferiram estatisticamente do tratamento controle a partir do $9^{\circ}$ dia $\mathrm{e}$ da dextrina ao $13^{\circ}$ dia. A coloração da solução de alginato, que é levemente marrom e também do $\mathrm{pH}$ mais elevado dessas amostras podem ainda ter colaborado para este resultado.

Murray \& Luft (1973) verificaram que a imersão de fatias de maçãs frescas uma solução (40\%) de hidrolisado de amido de 15 DE (dextrose equivalente) preveniu o escurecimento do tecido. O resultado foi atribuído ao 
retardamento da entrada de oxigênio, demonstrando que coberturas de amido hidrolisado (dextrinas) apresentam resistência a este gás.

Durante o armazenamento os tratamentos com solução conservadora, fécula de mandioca e dextrina mantiveram a coloração das maçãs MP do $1^{\circ}$ dia, não ocorrendo escurecimento significativo. No entanto, o controle e o alginato de sódio apresentaram variação significativa dos valores de L, embora sem tendência definida no tempo.

A análise de regressão (Figura 19) mostrou que apenas o tratamento controle apresentou equação significativa para valores de L no tempo, no caso, escurecimento de polpa no decorrer do armazenamento.

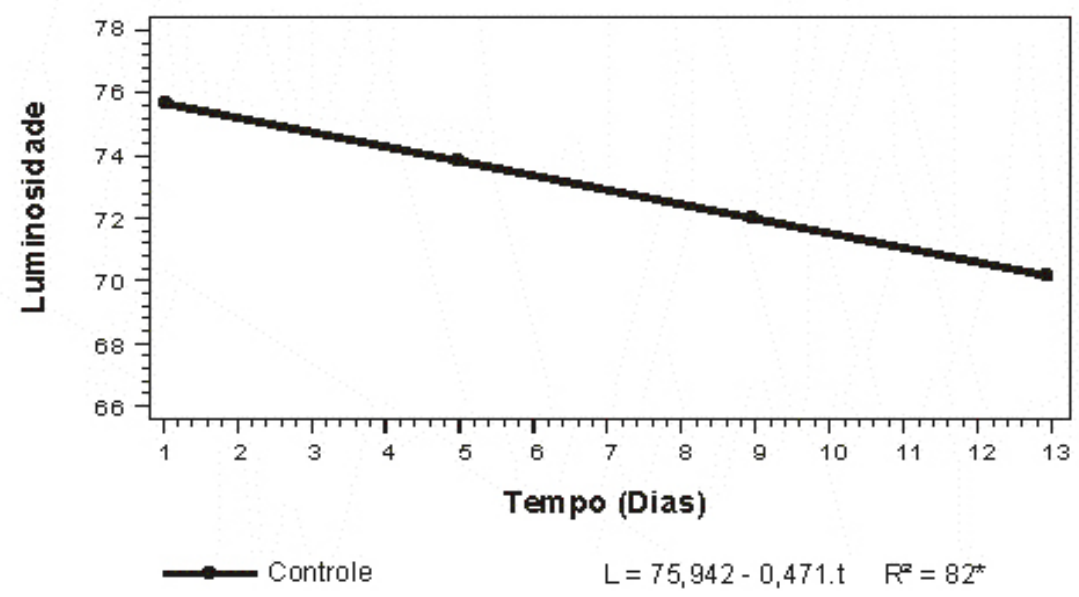

Figura 19 - Variação de Luminosidade (L) das maçãs controle sob armazenamento refrigerado

O croma $a^{*}$ indica intensidade das cores variando do verde $(-60)$ ao vermelho (+60). Embora significativas, as variações do croma a* das maçãs MP (Tabela 7) dos diferentes tratamentos, os valores situaram-se próximos do eixo central (Figura20), onde todas as cores se misturam, proporcionando uma coloração levemente marrom. 
Tabela 7. Croma $a^{\star}$ das maçãs MP em função dos tratamentos e do tempo de armazenamento

\begin{tabular}{lcccc}
\hline & \multicolumn{4}{c}{ Tempo de armazenamento (dias) } \\
\hline Tratamentos & 1 & 5 & 9 & 13 \\
\hline Controle & $-2,0$ a B & $-0,8$ a B & 1,5 a A & 2,6 a A \\
Solução conservadora & $-5,2$ b B & $-3,4$ b B & $-3,3$ c B & $-2,7$ c A \\
Fécula de mandioca & $-4,2$ b B & $-2,5$ ab AB & $-1,1$ b A & $-1,2$ b A \\
Dextrina de mandioca & $-4,5$ b B & $-1,6$ a A & $-1,0$ b A & $-0,3$ b A \\
Alginato de sódio & $-4,2$ b B & $-2,0$ a A & $-1,6$ b A & $-1,3$ b A \\
\hline
\end{tabular}

Médias seguidas de mesma letra minúscula na coluna e maiúscula na linha não diferem entre si, pelo Teste de Tukey em nível de $5 \%$ de probabilidade.

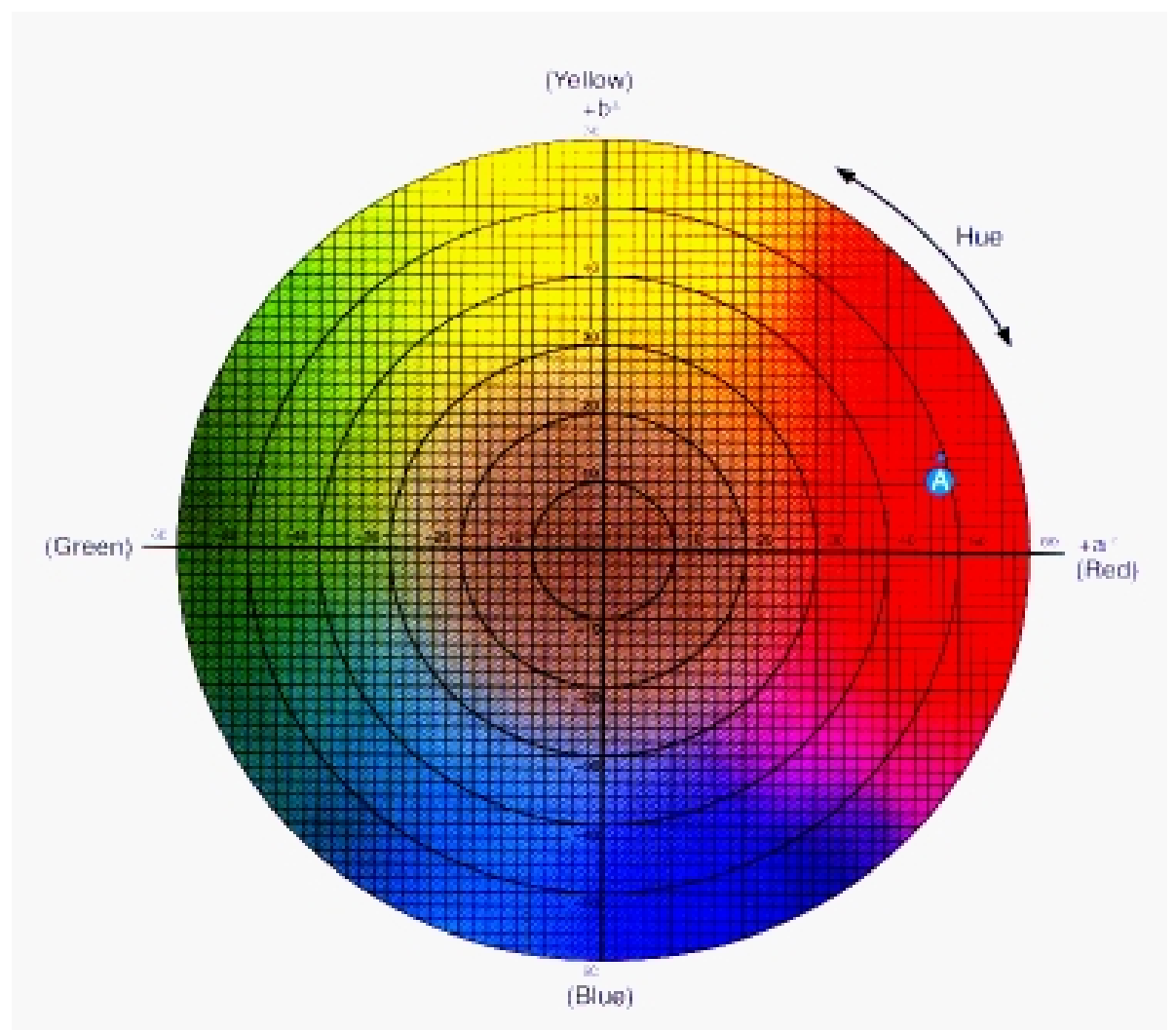

Figura 20 - Eixo dos valores de croma $a^{\star} e b^{*}$

Após 1 dia de armazenamento as maçãs MP controle apresentaram valores do croma $a^{\star}$ maiores que os demais tratamentos, cujos valores foram 
semelhantes entre si. A partir do $9^{\circ}$ dia, entretanto, tratamento controle se estabeleceu com os maiores valores do croma e o tratamento com solução conservadora com menores valores.

Os tratamentos com películas apresentaram mudança significativa no croma $\mathrm{a}^{\star}$ evidenciando a partir do $5^{\circ}$ dia de armazenamento valores mais próximos do zero. No tratamento controle o aumento foi verificado no $9^{\circ}$ dia de armazenamento e para as maçãs imersas em solução conservadora somente no $13^{\circ}$ dia de armazenamento.

O croma $b$ * indica intensidade das cores variando de azul (-60) a amarelo (+60). Os valores de croma $b^{*}$ das maçãs MP apresentaram-se positivos (Tabela 8), ou seja, mais próximos do amarelo.

Tabela 8. Croma $b^{\star}$ das maçãs MP em função dos tratamentos e do tempo de armazenamento

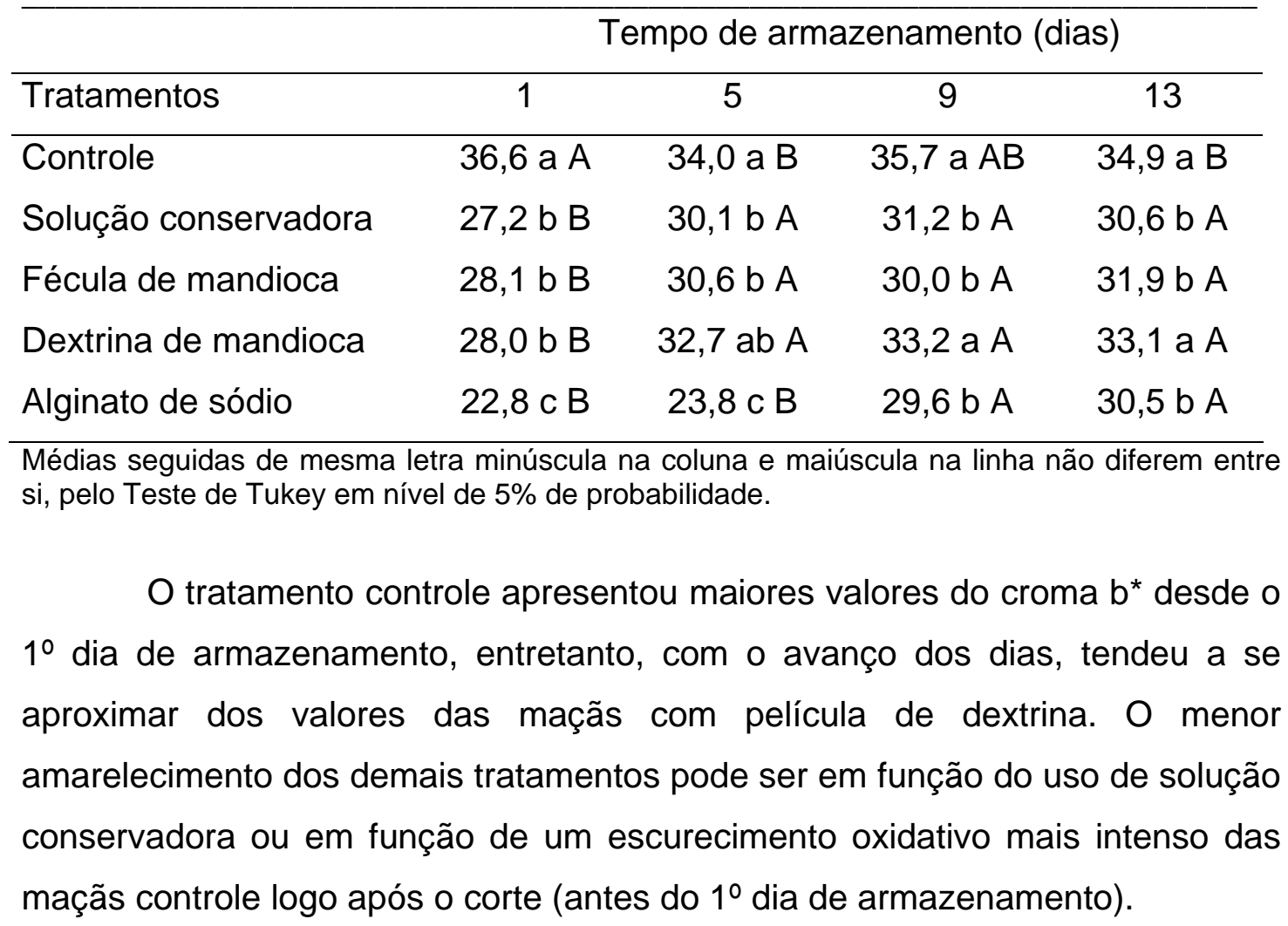


Ocorreram alterações do croma $b^{*}$ das maçãs MP ao longo do armazenamento para os demais tratamentos utilizados, mostrando tendência a aumento de intensidade do amarelo. A maioria dos tratamentos apresentou essas alterações a partir do $5^{\circ}$ dia de armazenamento.

\subsection{Microrganismos}

Nas análises microbiológicas realizadas nos diferentes tratamentos e tempos para Coliformes Totais e Fecais foi detectado ausência de microrganismos em $25 \mathrm{~g}$ das amostras analisadas. Este resultado representa que as condições higiênico-sanitárias durante o processamento foram satisfatórias e as maçãs MP estão de acordo com a legislação da ANVISA.

Para Salmonella também foi detectada ausência em $25 \mathrm{~g}$ da matériaprima antes do processamento, confirmando boas práticas de manejo na colheita e pós-colheita.

Os resultados obtidos por Pilon (2003) para cenoura e salada mista MP armazenadas sob ar atmosférico, vácuo e atmosfera modificada, foram negativos para presença de coliformes totais, fecais, anaeróbios mesófilos e Salmonella.

\subsection{Análise sensorial}

Após o treinamento, os provadores realizaram as análises sensoriais das maçãs MP conferindo notas aos atributos relacionados com a aparência (cor, escurecimento, uniformidade, brilho, umidade, artificial); aroma (maçã, doce, ácido); sabor (maçã, doce, salgado, ácido, fresca, amargo) e textura (maçã, maciez, umidade).

Os valores da probabilidade de $\mathrm{F}$ para as amostras oferecidas aos provadores foram significativos para a maioria dos parâmetros, ou seja, houve diferença sensorial em pelo menos uma amostra; nos parâmetros de aroma ácido e sabor amargo não houve essa diferença (Tabela 9). 
Tabela 9. Valores da probabilidade de F para amostra, provador e interação de amostra com provador

\begin{tabular}{lccc}
\hline Aparência & amostra & provador & amostra x provador \\
\hline cor característica de maçã & 0,0001 * & $0,26 \mathrm{~ns}$ & $0,91 \mathrm{~ns}$ \\
escurecimento & 0,0001 * & $0,36 \mathrm{~ns}$ & $0,86 \mathrm{~ns}$ \\
uniformidade de cor & 0,0001 * & $0,17 \mathrm{~ns}$ & $0,98 \mathrm{~ns}$ \\
brilho & 0,0001 * & $0,05 \mathrm{~ns}$ & $0,86 \mathrm{~ns}$ \\
umidade & 0,0001 * & $0,06 \mathrm{~ns}$ & $0,94 \mathrm{~ns}$ \\
aparência artificial & 0,0001 * & $0,61 \mathrm{~ns}$ & $0,99 \mathrm{~ns}$ \\
Aroma & & & \\
característico de maçã & 0,0001 * & $0,35 \mathrm{~ns}$ & $0,27 \mathrm{~ns}$ \\
doce & 0,0001 * & $0,05 \mathrm{~ns}$ & $0,09 \mathrm{~ns}$ \\
ácido & $0,13 \mathrm{~ns}$ & $0,23 \mathrm{~ns}$ & $0,95 \mathrm{~ns}$ \\
Sabor & & & \\
característico de maçã & 0,0002 * & $0,9 \mathrm{~ns}$ & $0,99 \mathrm{~ns}$ \\
doce & 0,0001 * & $0,64 \mathrm{~ns}$ & $0,98 \mathrm{~ns}$ \\
salgado & 0,0001 * & $0,98 \mathrm{~ns}$ & $1 \mathrm{~ns}$ \\
ácido & 0,0001 * & $0,65 \mathrm{~ns}$ & $0,99 \mathrm{~ns}$ \\
amargo & $0,64 \mathrm{~ns}$ & $0,05 \mathrm{~ns}$ & $0,93 \mathrm{~ns}$ \\
fruta fresca & 0,0001 * & $0,34 \mathrm{~ns}$ & $0,99 \mathrm{~ns}$ \\
Textura & & & \\
$\quad$ característica de maçã & 0,0017 * & $0,16 \mathrm{~ns}$ & $0,98 \mathrm{~ns}$ \\
maciez & 0,0001 * & $0,97 \mathrm{~ns}$ & $0,97 \mathrm{~ns}$ \\
umidade & 0,0001 * & $0,6 \mathrm{~ns}$ & $0,85 \mathrm{~ns}$ \\
\hline * significativo a nível de $5 \%$ & & & \\
ns = não significativo & & &
\end{tabular}

Os valores da probabilidade de $\mathrm{F}$ para provador não foi significativo para todos os parâmetros, isto significa que os provadores usaram as mesmas proporções da escala para uma mesma amostra.

A interação entre amostra e provador também não mostrou-se significativa para todos os parâmetros, isto demonstra homogeneidade dos provadores.

\subsubsection{Aparência}

\subsubsection{Cor}

As maçãs MP apresentaram variação significativa de cor (Tabela 10) entre os tratamentos dentro de cada tempo de armazenamento e dentro de cada tratamento entre os dias de armazenamento, em nível de 5\%. 
Tabela 10. Médias das notas dos provadores para cor das maçãs MP em função dos tratamentos e do tempo de armazenamento

\begin{tabular}{lcccc}
\hline & \multicolumn{4}{c}{ Tempo de armazenamento (dias) } \\
\hline Tratamentos & 1 & 5 & 9 & 13 \\
\hline Controle & $1,5 \mathrm{dA}$ & $1,0 \mathrm{cA}$ & $0,8 \mathrm{cA}$ & $0,7 \mathrm{cA}$ \\
Solução conservadora & $9,6 \mathrm{aA}$ & $9,1 \mathrm{aA}$ & $8,1 \mathrm{aA}$ & $6,8 \mathrm{aB}$ \\
Fécula de mandioca & $8,0 \mathrm{bcA}$ & $4,8 \mathrm{bB}$ & $3,7 \mathrm{bB}$ & $3,3 \mathrm{bB}$ \\
Dextrina de mandioca & $7,5 \mathrm{cA}$ & $4,7 \mathrm{bB}$ & $4,2 \mathrm{bB}$ & $3,6 \mathrm{bB}$ \\
Alginato de sódio & $9,1 \mathrm{abA}$ & $5,6 \mathrm{bB}$ & $3,7 \mathrm{cB}$ & $3,8 \mathrm{bB}$ \\
\hline Médias seguidas de mesma letra minúscula na coluna e maiúscula na linha não diferem entre \\
si, pelo Teste de Tukey em nível de 5\% de probabilidade.
\end{tabular}

As maçãs MP imersas em solução conservadora apresentaram as maiores notas de cor, ou seja, mostraram-se mais próximas do natural, em todos os dias avaliados. Em oposição, há o tratamento controle, com coloração mais distinta do natural.

No tratamento controle, após 1 dia de armazenamento, a coloração da amostra já havia se diferenciado muito do que é natural, mostrando que alterações consideráveis neste parâmetro ocorrem nas primeiras horas após o corte do vegetal.

As maçãs MP imersas em solução conservadora apresentaram notas de cor significativamente diferentes apenas no $13^{\circ}$ dia. No entanto, as maçãs MP recobertas com películas mostraram colorações não muito longe da natural no $1^{\circ}$ dia de armazenamento, mas ao $5^{\circ}$ dia, as modificações se mostraram bem intensas, com redução de notas que não diferiram estatisticamente.

\subsubsection{Escurecimento}

O escurecimento é um parâmetro de aparência que compõe a cor das maçãs MP considerado pelos provadores na avaliação do parâmetro anterior (cor). Isto é mostrado pela Tabela 11 onde o maior escurecimento foi apresentado pelo tratamento controle e o menor pelas maçãs MP imersas em solução conservadora. Mostrou também que o escurecimento enzimático se 
desenvolve rapidamente após o momento do corte. O menor escurecimento do tratamento com solução conservadora evidenciou o efeito significativo dos agentes antioxidantes presentes na solução. Esta resposta também confirma a análise instrumental (colorímetro), que apresentou resultados coincidentes com luminosidade.

Tabela 11. Médias das notas dos provadores para escurecimento das maçãs MP em função dos tratamentos e do tempo de armazenamento

\begin{tabular}{lcccc}
\hline & & \multicolumn{3}{c}{ Tempo de armazenamento (dias) } \\
\hline Tratamentos & 1 & 5 & 9 & 13 \\
\hline Controle & $7,7 \mathrm{aA}$ & $8,6 \mathrm{aA}$ & $8,6 \mathrm{aA}$ & $9,3 \mathrm{aA}$ \\
Solução conservadora & $0,2 \mathrm{dA}$ & $0,3 \mathrm{cA}$ & $0,6 \mathrm{cA}$ & $1,5 \mathrm{cA}$ \\
Fécula de mandioca & $2,0 \mathrm{cA}$ & $4,2 \mathrm{bB}$ & $4,8 \mathrm{bB}$ & $5,1 \mathrm{bB}$ \\
Dextrina de mandioca & $4,0 \mathrm{bA}$ & $4,1 \mathrm{~b} \mathrm{~A}$ & $5,3 \mathrm{bA}$ & $5,3 \mathrm{bA}$ \\
Alginato de sódio & $0,6 \mathrm{cdA}$ & $2,8 \mathrm{bA}$ & $6,1 \mathrm{bB}$ & $5,3 \mathrm{bB}$
\end{tabular}

Médias seguidas de mesma letra minúscula na coluna e maiúscula na linha não diferem entre si, pelo Teste de Tukey em nível de 5\% de probabilidade.

Os tratamentos controle, solução conservadora e dextrina não apresentaram diferença significativa de escurecimento oxidativo em função do tempo de armazenamento estudado. Somente as maçãs MP com película de fécula de mandioca e alginato mostraram tendência significativa ao escurecimento a partir do $5^{\circ}$ e $9^{\circ}$ dias de armazenamento refrigerado, respectivamente.

\subsubsection{Uniformidade de cor}

O parâmetro uniformidade de cor das maçãs MP (Tabela 12) apresentou variação significativa entre os tratamentos dentro de cada tempo de armazenamento e para cada tratamento entre os dias de armazenamento. 
Tabela 12. Médias das notas dos provadores para uniformidade de cor das maçãs MP em função dos tratamentos e do tempo de armazenamento

\begin{tabular}{lcccc}
\hline & \multicolumn{4}{c}{ Tempo de armazenamento (dias) } \\
\hline Tratamentos & 1 & 5 & 9 & 13 \\
\hline Controle & $6,3 \mathrm{cA}$ & $2,8 \mathrm{cB}$ & $2,0 \mathrm{bB}$ & $2,3 \mathrm{~dB}$ \\
Solução conservadora & $9,5 \mathrm{aA}$ & $9,1 \mathrm{aA}$ & $6,1 \mathrm{aB}$ & $6,3 \mathrm{aB}$ \\
Fécula de mandioca & $6,7 \mathrm{bcA}$ & $5,1 \mathrm{bB}$ & $3,7 \mathrm{bB}$ & $3,6 \mathrm{cB}$ \\
Dextrina de mandioca & $7,1 \mathrm{bcA}$ & $5,6 \mathrm{bB}$ & $4,1 \mathrm{abB}$ & $4,6 \mathrm{bcB}$ \\
Alginato de sódio & $8,6 \mathrm{abA}$ & $5,1 \mathrm{bB}$ & $5,1 \mathrm{aB}$ & $6,0 \mathrm{abB}$ \\
\hline Médias seguidas de mesma letra minúscula na coluna e maiúscula na linha não diferem entre \\
si, pelo Teste de Tukey em nível de 5\% de probabilidade.
\end{tabular}

Além de considerar as maçãs MP imersas em solução conservadora como de coloração mais próxima do natural e de menor escurecimento, os provadores as classificaram como sendo as mais homogêneas com relação à coloração. Em contrapartida, o tratamento controle que mostrou-se com coloração mais diferenciada do natural e com maior escurecimento foi identificada pelos provadores como sendo heterogênea e justificada nas observações da ficha de análise descritiva quantitativa que o escurecimento não ocorre de forma homogênea na fruta, e sim como pequenas manchas, que vão aumentando com o armazenamento.

Em todos os tratamentos, a desuniformidade de cor foi verificada no $5^{\circ}$ dia de armazenamento, exceto para a solução conservadora que foi a partir do $9^{\circ}$ dia de armazenamento.

\subsubsection{Brilho}

O tratamento com alginato foi o único a apresentar maçãs MP com brilho considerável, em função do tipo de película formada. Queda significativa do brilho foi detectada apenas no $9^{\circ}$ dia de armazenamento para este tratamento, muito embora fosse este ainda um brilho superior aos demais pedaços de maçãs MP (Tabela 13). 
Tabela 13. Médias das notas dos provadores para brilho das maçãs MP em função dos tratamentos e do tempo de armazenamento

\begin{tabular}{lcccc}
\hline & \multicolumn{4}{c}{ Tempo de armazenamento (dias) } \\
\hline Tratamentos & 1 & 5 & 9 & 13 \\
\hline Controle & $0,2 \mathrm{cA}$ & $1,1 \mathrm{bA}$ & $1,0 \mathrm{bA}$ & $1,0 \mathrm{bA}$ \\
Solução conservadora & $1,0 \mathrm{bcA}$ & $1,1 \mathrm{bA}$ & $1,1 \mathrm{bA}$ & $1,2 \mathrm{bA}$ \\
Fécula de mandioca & $2,0 \mathrm{bA}$ & $1,7 \mathrm{bA}$ & $1,6 \mathrm{bA}$ & $1,6 \mathrm{bA}$ \\
Dextrina de mandioca & $1,0 \mathrm{bcA}$ & $2,3 \mathrm{bA}$ & $1,2 \mathrm{bA}$ & $2,1 \mathrm{bA}$ \\
Alginato de sódio & $9,5 \mathrm{aA}$ & $8,3 \mathrm{aA}$ & $5,2 \mathrm{aB}$ & $5,1 \mathrm{aB}$ \\
\hline Médias seguidas de mesma letra minúscula na coluna e maiúscula na linha não diferem entre \\
si, pelo Teste de Tukey em nível de 5\% de probabilidade.
\end{tabular}

\subsubsection{Umidade}

As maçãs MP que apresentaram-se menos úmidas foram as do tratamento controle que, no entanto, não diferiram estatisticamente da solução conservadora a partir do $5^{0}$ dia de armazenamento (Tabela 14). Em contrapartida, os tratamentos com película mostraram-se mais suculentos, com destaque para a cobertura de alginato de sódio que apresentou umidade bastante diferenciada. Possivelmente, a película seja mais eficiente em reter a umidade das maçãs cortadas. Estes resultados concordam com os obtidos nas análises físico-químicas de umidade.

No decorrer do armazenamento os tratamentos, controle e alginato, não ocasionaram variação significativa de umidade das maçãs MP. As coberturas de fécula de mandioca e dextrina tornaram-se significativamente mais secas a partir do $9^{\circ}$ dia de armazenamento. No tratamento com solução conservadora, a variação da umidade das amostras foi detectada mais precocemente no $5^{\circ}$ dia de armazenamento, fato que pode ser decorrente da ausência de películas e a presença de $\mathrm{NaCl}$ na solução que promovem um ressecamento superficial das maçãs MP. 
Tabela 14. Médias das notas dos provadores para umidade das maçãs MP em função dos tratamentos e do tempo de armazenamento

\begin{tabular}{lcccc}
\hline & \multicolumn{4}{c}{ Tempo de armazenamento (dias) } \\
\hline Tratamentos & 1 & 5 & 9 & 13 \\
\hline Controle & $2,3 \mathrm{dA}$ & $1,5 \mathrm{cA}$ & $0,8 \mathrm{cA}$ & $0,8 \mathrm{cA}$ \\
Solução conservadora & $7,7 \mathrm{bA}$ & $2,7 \mathrm{cB}$ & $1,5 \mathrm{bcB}$ & $2,0 \mathrm{cB}$ \\
Fécula de mandioca & $7,3 \mathrm{bA}$ & $6,2 \mathrm{bA}$ & $3,3 \mathrm{bB}$ & $3,7 \mathrm{bB}$ \\
Dextrina de mandioca & $5,3 \mathrm{cA}$ & $5,8 \mathrm{bA}$ & $3,0 \mathrm{bB}$ & $3,7 \mathrm{bB}$ \\
Alginato de sódio & $9,2 \mathrm{aA}$ & $8,6 \mathrm{aA}$ & $7,6 \mathrm{aA}$ & $8,2 \mathrm{aA}$ \\
\hline
\end{tabular}

Médias seguidas de mesma letra minúscula na coluna e maiúscula na linha não diferem entre si, pelo Teste de Tukey em nível de $5 \%$ de probabilidade.

\subsubsection{Artificial}

As notas atribuídas pelos provadores ao parâmetro aspecto artificial das amostras em diferentes tratamentos e períodos de armazenamento são apresentadas na Tabela 15.

O tratamento com alginato de sódio conferiu uma aparência diferenciada às maçãs MP, denominada artificial pelos provadores, fato que pode ser atribuído à espessura visível da película e ao seu brilho. Esta aparência diferenciada do natural tendeu a diminuir após 0 9o dia de armazenamento, chegando a se aproximar dos demais tratamentos possivelmente devido à perda significativa de brilho, ao escurecimento e à perda de umidade destas amostras.

As coberturas de fécula de mandioca e dextrina não conferiram o mesmo efeito artificial às maçãs MP que as maçãs recobertas com alginato $\mathrm{e}$ com o aumento do período de armazenamento mostraram notas que conferem um aspecto bem próximo do natural. Para o tratamento com solução conservadora e alginato, a tendência à aparência artificial foi verificada no $9^{\circ}$ dia de armazenamento, e para o tratamento controle esta tendência foi detectada apenas no $13^{\circ}$ dia de armazenamento refrigerado. 
Tabela 15. Médias das notas dos provadores para aparência artificial das maçãs MP em função dos tratamentos e do tempo de armazenamento

\begin{tabular}{lcccc}
\hline & \multicolumn{4}{c}{ Tempo de armazenamento (dias) } \\
\hline Tratamentos & 1 & 5 & 9 & 13 \\
\hline Controle & $0,8 \mathrm{bA}$ & $1,1 \mathrm{bA}$ & $1,6 \mathrm{abA}$ & $2,6 \mathrm{aB}$ \\
Solução conservadora & $0,5 \mathrm{bA}$ & $0,7 \mathrm{bA}$ & $2,0 \mathrm{aB}$ & $2,6 \mathrm{aB}$ \\
Fécula de mandioca & $1,1 \mathrm{bA}$ & $1,2 \mathrm{bA}$ & $0,7 \mathrm{bA}$ & $0,8 \mathrm{bA}$ \\
Dextrina de mandioca & $0,5 \mathrm{bA}$ & $1,5 \mathrm{bA}$ & $0,8 \mathrm{bA}$ & $0,8 \mathrm{bA}$ \\
Alginato de sódio & $8,5 \mathrm{aA}$ & $7,8 \mathrm{aA}$ & $2,5 \mathrm{aB}$ & $1,8 \mathrm{abB}$ \\
\hline Médias seguidas de mesma letra minúscula na coluna e maiúscula na linha não diferem entre \\
si, pelo Testede Tukey em nível de 5\% de probabilidade.
\end{tabular}

A análise sensorial das maçãs MP quanto à aparência geral mostrou que a solução conservadora obteve as melhores notas em relação à cor, escurecimento e uniformidade de cor. O tratamento com alginato de sódio apresentou uma maçã MP com película visível e aspecto brilhante, fato que os provadores associaram como sendo de aparência artificial. Em relação à umidade, os provadores escolheram as maçãs com película como sendo as mais úmidas, com destaque para o alginato.

\subsubsection{Aroma}

\subsubsection{Maçã}

No $1^{\circ}$ dia de armazenamento refrigerado não houve diferença significativa entre o aroma das maçãs MP obtidas pelos diferentes tratamentos, como pode ser observado na Tabela 16. Posteriormente, o tratamento com solução conservadora, tendeu a se diferenciar dos demais por apresentar aroma mais próximo do natural. Há que se considerar, entretanto, que as maiores notas atribuídas a este tratamento podem ser pela presença de ácidos na solução conservadora, que induziu o provador a compará-lo com o aroma natural de maçã. 
Os tratamentos, controle e alginato, apresentaram maçãs MP com diferença significativa no aroma característico de maçã a partir do $5^{\circ}$ dia de armazenamento refrigerado. Os tratamentos com película de fécula de mandioca e dextrina apresentaram esta perda de aroma a partir do $9^{\circ}$ dia de armazenamento refrigerado e a solução conservadora apenas no $13^{\circ}$ dia.

Tabela 16. Médias das notas dos provadores para aroma das maçãs MP em função dos tratamentos e do tempo de armazenamento

\begin{tabular}{lcccc}
\hline & \multicolumn{4}{c}{ Tempo de armazenamento (dias) } \\
\hline Tratamentos & 1 & 5 & 9 & 13 \\
\hline Controle & $7,8 \mathrm{aA}$ & $4,6 \mathrm{bcB}$ & $3,2 \mathrm{bBC}$ & $2,0 \mathrm{bC}$ \\
Solução conservadora & $7,3 \mathrm{aA}$ & $7,1 \mathrm{aA}$ & $7,0 \mathrm{aA}$ & $5,0 \mathrm{aB}$ \\
Fécula de mandioca & $7,6 \mathrm{aA}$ & $5,5 \mathrm{abA}$ & $2,8 \mathrm{bB}$ & $3,1 \mathrm{abB}$ \\
Dextrina de mandioca & $7,7 \mathrm{aA}$ & $6,1 \mathrm{abA}$ & $3,8 \mathrm{bB}$ & $3,5 \mathrm{abB}$ \\
Alginato de sódio & $8,7 \mathrm{aA}$ & $3,5 \mathrm{cB}$ & $2,0 \mathrm{bB}$ & $2,2 \mathrm{bB}$ \\
\hline Médias seguidas de mesma letra minúscula na coluna e maiúscula na linha não diferem entre & \multicolumn{4}{l}{} \\
si, pelo Teste de Tukey em nível de 5\% de probabilidade.
\end{tabular}

\subsubsection{Doce}

O aroma doce das maçãs MP se mostrou diferenciado entre os tratamentos apenas no $1^{\circ}$ dia de armazenamento refrigerado, com o tratamento controle destacando-se com aroma mais próximo do natural. Posteriormente, esta diferença de aroma entre os tratamentos não foi mais detectada pelos provadores (Tabela 17). 
Tabela 17. Médias das notas dos provadores para aroma doce das maçãs MP em função dos tratamentos e do tempo de armazenamento

\begin{tabular}{lcccc}
\hline & \multicolumn{4}{c}{ Tempo de armazenamento (dias) } \\
\hline Tratamentos & 1 & 5 & 9 & 13 \\
\hline Controle & $6,1 \mathrm{aA}$ & $3,0 \mathrm{aB}$ & $2,2 \mathrm{aB}$ & $1,6 \mathrm{aB}$ \\
Solução conservadora & $2,6 \mathrm{bcA}$ & $3,0 \mathrm{aA}$ & $2,5 \mathrm{aA}$ & $2,5 \mathrm{aA}$ \\
Fécula de mandioca & $3,3 \mathrm{bA}$ & $3,2 \mathrm{aA}$ & $2,0 \mathrm{aA}$ & $1,3 \mathrm{aA}$ \\
Dextrina de mandioca & $3,1 \mathrm{bA}$ & $2,6 \mathrm{aA}$ & $1,6 \mathrm{aA}$ & $2,1 \mathrm{aA}$ \\
Alginato de sódio & $1,2 \mathrm{cA}$ & $2,8 \mathrm{aA}$ & $1,5 \mathrm{aA}$ & $1,1 \mathrm{aA}$ \\
\hline
\end{tabular}

Médias seguidas de mesma letra minúscula na coluna e maiúscula na linha não diferem entre si, pelo Teste de Tukey em nível de 5\% de probabilidade.

Somente o tratamento controle apresentou diferença significativa a partir do $5^{\circ}$ dia de armazenamento refrigerado, com redução do aroma doce das maçãs MP ao mesmo nível dos aromas dos demais tratamentos.

\subsubsection{3 Ácido}

O aroma ácido não apresentou diferença significativa em relação aos tratamentos dentro de cada tempo de armazenamento e nem entre os dias de armazenamento (Tabela 18).

Tabela 18. Médias das notas dos provadores para aroma ácido das maçãs MP em função dos tratamentos do tempo de armazenamento

\begin{tabular}{lcccc}
\hline & \multicolumn{4}{c}{ Tempo de armazenamento (dias) } \\
\hline Tratamentos & 1 & 5 & 9 & 13 \\
\hline Controle & $1,2 \mathrm{aA}$ & $2,1 \mathrm{aA}$ & $1,2 \mathrm{aA}$ & $1,6 \mathrm{aA}$ \\
Solução conservadora & $1,7 \mathrm{aA}$ & $2,5 \mathrm{aA}$ & $2,5 \mathrm{aA}$ & $1,7 \mathrm{aA}$ \\
Fécula de mandioca & $1,7 \mathrm{aA}$ & $1,7 \mathrm{aA}$ & $2,0 \mathrm{aA}$ & $1,5 \mathrm{aA}$ \\
Dextrina de mandioca & $1,8 \mathrm{aA}$ & $1,6 \mathrm{aA}$ & $1,3 \mathrm{aA}$ & $1,5 \mathrm{aA}$ \\
Alginato de sódio & $0,7 \mathrm{aA}$ & $2,1 \mathrm{aA}$ & $1,6 \mathrm{aA}$ & $0,7 \mathrm{aA}$ \\
\hline
\end{tabular}

Médias seguidas de mesma letra minúscula na coluna e maiúscula na linha não diferem entre si, pelo Teste de Tukey em nível de 5\% de probabilidade. 
Nos parâmetros analisados para aroma das maçãs MP foi verificado que a solução conservadora apresentou as melhores notas em relação ao aroma natural de maçã. Os aromas doce e ácido praticamente não apresentaram diferença significativa entre os tratamentos ou com o tempo de armazenamento.

\subsubsection{Sabor}

\subsubsection{Maçã}

Maçãs MP que receberam o tratamento com solução conservadora apresentaram no $1^{\circ}$ dia de armazenamento as menores notas de sabor característico do produto, no entanto, não houve diferença significativa, entre estas notas e as conferidas ao produto tratado com fécula de mandioca (Tabela 19). Esta diferença entre tratamentos tendeu a desaparecer dentro dos tempos de armazenamento, se igualando ao final.

Em todos os tratamentos ocorreu uma perda significativa de sabor característico de maçã no $9^{\circ}$ dia de armazenamento, exceto para o alginato de sódio que apresentou redução considerável de aroma no $5^{\circ}$ dia de armazenamento, possivelmente pela presença da película de revestimento.

Tabela 19. Médias das notas dos provadores para sabor de maçã MP em função dos tratamentos e do tempo de armazenamento

\begin{tabular}{lcccc}
\hline & \multicolumn{4}{c}{ Tempo de armazenamento (dias) } \\
\hline Tratamentos & 1 & 5 & 9 & 13 \\
\hline Controle & $8,0 \mathrm{abA}$ & $6,8 \mathrm{aA}$ & $4,1 \mathrm{abB}$ & $3,2 \mathrm{aB}$ \\
Solução conservadora & $6,2 \mathrm{bA}$ & $7,6 \mathrm{aA}$ & $4,2 \mathrm{abB}$ & $4,1 \mathrm{aB}$ \\
Fécula de mandioca & $7,8 \mathrm{abA}$ & $6,3 \mathrm{aA}$ & $3,8 \mathrm{abB}$ & $3,8 \mathrm{aB}$ \\
Dextrina de mandioca & $8,6 \mathrm{aA}$ & $7,5 \mathrm{aA}$ & $5,2 \mathrm{aB}$ & $5,2 \mathrm{aB}$ \\
Alginato de sódio & $8,5 \mathrm{aA}$ & $3,2 \mathrm{bB}$ & $3,0 \mathrm{bB}$ & $3,3 \mathrm{aB}$ \\
\hline Médias seguidas de mesma letra minúscula na coluna e maiúscula na linha não diferem entre \\
si, pelo Teste de Tukey em nível de 5\% de probabilidade.
\end{tabular}




\subsubsection{Doce}

Os tratamentos controle, fécula de mandioca e dextrina apresentaram maçãs MP com notas para doçura mais próxima do natural significativamente mais elevadas que os demais tratamentos (Tabela 20). No $13^{\circ}$ dia de armazenamento, a doçura tendeu a igualar-se entre as maçãs MP tratadas de modos diversos.

Os tratamentos com solução conservadora e alginato não apresentaram variação significativa em relação ao sabor doce, sempre baixo, das maçãs MP durante o armazenamento. No entanto, os tratamentos controle e fécula de mandioca começaram a perder significativamente o sabor doce natural a partir do $9^{\circ}$ dia de armazenamento e o tratamento dextrina foi o que perdeu o sabor doce apenas no último dia de armazenamento refrigerado.

Tabela 20. Médias das notas dos provadores para sabor doce das maçãs MP em função dos tratamentos e do tempo de armazenamento

\begin{tabular}{lcccc}
\hline & \multicolumn{4}{c}{ Tempo de armazenamento (dias) } \\
\hline Tratamentos & 1 & 5 & 9 & 13 \\
\hline Controle & $7,3 \mathrm{aA}$ & $6,1 \mathrm{aA}$ & $4,6 \mathrm{aB}$ & $2,5 \mathrm{aC}$ \\
Solução conservadora & $1,2 \mathrm{bA}$ & $2,7 \mathrm{bA}$ & $2,3 \mathrm{bA}$ & $2,5 \mathrm{aA}$ \\
Fécula de mandioca & $7,0 \mathrm{aA}$ & $6,0 \mathrm{aA}$ & $4,6 \mathrm{aAB}$ & $2,6 \mathrm{aB}$ \\
Dextrina de mandioca & $6,1 \mathrm{aA}$ & $5,6 \mathrm{aA}$ & $5,0 \mathrm{aA}$ & $2,5 \mathrm{aB}$ \\
Alginato de sódio & $1,8 \mathrm{bA}$ & $3,3 \mathrm{bA}$ & $2,0 \mathrm{bA}$ & $1,1 \mathrm{aA}$ \\
\hline Médias seguidas de mesma letra minúscula na coluna e maiúscula na linha não diferem entre \\
si, pelo Teste de Tukey em nível de 5\% de probabilidade.
\end{tabular}

\subsubsection{Salgado}

O tratamento com solução conservadora apresentou maçãs MP com maiores notas para sabor salgado, nos primeiros dias de armazenamento (Tabela 21). O sabor salgado provavelmente esteja advindo dos componentes (sal e ácidos) adicionados a solução conservadora. Esta percepção diferenciada de sabor salgado, entretanto, tendeu a um nivelamento com o tempo de armazenamento, desaparecendo no $9^{\circ}$ dia. 
O tratamento da solução conservadora apresentou redução significativa do sabor salgado com o tempo de armazenamento.

Tabela 21. Médias das notas dos provadores para sabor salgado das maçãs MP em função dos tratamentos e do tempo de armazenamento

\begin{tabular}{lcccc}
\hline & \multicolumn{4}{c}{ Tempo de armazenamento (dias) } \\
\hline Tratamentos & 1 & 5 & 9 & 13 \\
\hline Controle & $0 \mathrm{bA}$ & $0,2 \mathrm{bA}$ & $0,5 \mathrm{aA}$ & $0,3 \mathrm{aA}$ \\
Solução conservadora & $7,0 \mathrm{aA}$ & $5,1 \mathrm{aB}$ & $1,5 \mathrm{aC}$ & $0,2 \mathrm{aC}$ \\
Fécula de mandioca & $0,2 \mathrm{bA}$ & $0,7 \mathrm{bA}$ & $0,5 \mathrm{aA}$ & $0,5 \mathrm{aA}$ \\
Dextrina de mandioca & $0 \mathrm{bA}$ & $0,7 \mathrm{bA}$ & $0,3 \mathrm{aA}$ & $0,2 \mathrm{aA}$ \\
Alginato de sódio & $0,1 \mathrm{bA}$ & $0,6 \mathrm{bA}$ & $0,8 \mathrm{aA}$ & $0,2 \mathrm{aA}$ \\
\hline
\end{tabular}

Médias seguidas de mesma letra minúscula na coluna e maiúscula na linha não diferem entre si, pelo Teste de Tukey em nível de $5 \%$ de probabilidade.

\subsubsection{4 Ácido}

O tratamento da solução conservadora apresentou as maiores notas, ou seja, as maçãs MP deste tratamento mostraram-se mais ácidas, resultado já esperado. No entanto, este tratamento não diferiu estatisticamente do controle em todos os períodos de armazenamento (Tabela 22).

No $1^{\circ}$ dia de armazenamento as maçãs MP tratadas com fécula de mandioca e alginato mostraram inibição significativa da acidez dos produtos, entretanto, esta diferença tendeu a desaparecer conforme o tempo de armazenamento avançou.

A partir do $9^{\circ}$ dia de armazenamento não houve diferença significativa para sabor ácido entre os tratamentos. Possivelmente, a maior acidez promovida pelos ácidos presentes na solução conservadora sofra uma diluição e/ou evaporação. Este resultado concorda com o obtido pela análise físicoquímica de acidez total titulável.

As coberturas de dextrina e alginato não apresentaram diferença significativa em relação ao tempo de armazenamento, no entanto, os demais 
tratamentos apresentaram diferença significativa no $5^{\circ}$ dia de armazenamento refrigerado.

Tabela 22. Médias das notas dos provadores para sabor ácido das maçãs MP em função dos tratamentos e do tempo de armazenamento

\begin{tabular}{lcccc}
\hline & \multicolumn{4}{c}{ Tempo de armazenamento (dias) } \\
\hline Tratamentos & 1 & 5 & 9 & 13 \\
\hline Controle & $7,8 \mathrm{aA}$ & $3,0 \mathrm{abB}$ & $1,7 \mathrm{aB}$ & $1,3 \mathrm{aB}$ \\
Solução conservadora & $7,7 \mathrm{aA}$ & $4,3 \mathrm{aB}$ & $2,7 \mathrm{aB}$ & $2,2 \mathrm{aB}$ \\
Fécula de mandioca & $0,7 \mathrm{cB}$ & $3,3 \mathrm{aA}$ & $1,6 \mathrm{aA}$ & $1,7 \mathrm{aA}$ \\
Dextrina de mandioca & $3,2 \mathrm{bA}$ & $2,7 \mathrm{bA}$ & $1,5 \mathrm{aA}$ & $1,5 \mathrm{aA}$ \\
Alginato de sódio & $0,6 \mathrm{cA}$ & $1,6 \mathrm{bA}$ & $1,6 \mathrm{aA}$ & $1,2 \mathrm{aA}$ \\
\hline
\end{tabular}

Médias seguidas de mesma letra minúscula na coluna e maiúscula na linha não diferem entre si, pelo Teste de Tukey em nível de $5 \%$ de probabilidade.

\subsubsection{Fresca}

Os tratamentos com solução conservadora, fécula de mandioca e dextrina de fécula de mandioca apresentaram as maiores notas e não houve diferença significativa entre estes tratamentos dentro de cada tempo de armazenamento. Em contrapartida, os tratamentos controle e alginato de sódio tenderam a apresentar maçãs MP com notas mais baixas, evidenciando um sabor de fruta velha (Tabela 23). O tratamento controle pelo envelhecimento natural e o com alginato de sódio pelo sabor da própria película.

Quase todos os tratamentos tenderam a mostrar perda significativa de frescor dos produtos com o tempo de armazenamento, exceto a cobertura de alginato, que não apresentou mudança significativa no sabor de fruta velha que pronunciou-se desde o início e manteve-se constante.

O tratamento controle apresentou diferença significativa logo no $5^{\circ}$ dia de armazenamento, em seguida o tratamento de fécula de mandioca com diferenciação no $9^{\circ}$ dia. Em contrapartida, os tratamentos com solução conservadora e dextrina, foram apresentar diferenciação do sabor de fruta 
fresca apenas no $13^{\circ}$ dia. A cobertura de alginato não apresentou mudança significativa no sabor de fruta fresca das maçãs MP.

Tabela 23. Médias das notas dos provadores para sabor de fruta fresca das maçãs MP em função dos tratamentos e do tempo de armazenamento

\begin{tabular}{lcccc}
\hline & \multicolumn{4}{c}{ Tempo de armazenamento (dias) } \\
\hline Tratamentos & 1 & 5 & 9 & 13 \\
\hline Controle & $5,1 \mathrm{abA}$ & $2,8 \mathrm{bB}$ & $2,8 \mathrm{bB}$ & $1,0 \mathrm{bB}$ \\
Solução conservadora & $5,8 \mathrm{aA}$ & $5,3 \mathrm{aA}$ & $4,3 \mathrm{aA}$ & $3,7 \mathrm{aB}$ \\
Fécula de mandioca & $6,6 \mathrm{aA}$ & $5,5 \mathrm{aA}$ & $3,8 \mathrm{abB}$ & $3,6 \mathrm{aB}$ \\
Dextrina de mandioca & $6,6 \mathrm{aA}$ & $6,1 \mathrm{aA}$ & $5,5 \mathrm{aA}$ & $3,8 \mathrm{aB}$ \\
Alginato de sódio & $3,8 \mathrm{bA}$ & $2,7 \mathrm{bA}$ & $2,3 \mathrm{bA}$ & $2,1 \mathrm{bA}$ \\
\hline
\end{tabular}

Médias seguidas de mesma letra minúscula na coluna e maiúscula na linha não diferem entre si, pelo Teste de Tukey em nível de $5 \%$ de probabilidade.

\subsubsection{Amargo}

O atributo sabor amargo não apresentou diferença significativa, em relação aos tratamentos e ao tempo de armazenamento, como pode ser observado na Tabela 24.

Tabela 24. Médias das notas dos provadores para sabor amargo das maçãs MP em função dos tratamentos e do tempo de armazenamento

\begin{tabular}{lcccc}
\hline & \multicolumn{4}{c}{ Tempo de armazenamento (dias) } \\
\hline Tratamentos & 1 & 5 & 9 & 13 \\
\hline Controle & $0 \mathrm{aA}$ & $0,6 \mathrm{aA}$ & $0,7 \mathrm{aA}$ & $0,7 \mathrm{aA}$ \\
Solução conservadora & $0,2 \mathrm{aA}$ & $0,6 \mathrm{aA}$ & $0,2 \mathrm{aA}$ & $0,2 \mathrm{aA}$ \\
Fécula de mandioca & $0,2 \mathrm{aA}$ & $0,7 \mathrm{aA}$ & $0,6 \mathrm{aA}$ & $0,6 \mathrm{aA}$ \\
Dextrina de mandioca & $0 \mathrm{aA}$ & $1,0 \mathrm{aA}$ & $0,3 \mathrm{aA}$ & $0,3 \mathrm{aA}$ \\
Alginato de sódio & $0,1 \mathrm{aA}$ & $0,8 \mathrm{aA}$ & $0,6 \mathrm{aA}$ & $0,6 \mathrm{aA}$ \\
\hline
\end{tabular}

Médias seguidas de mesma letra minúscula na coluna e maiúscula na linha não diferem entre si, pelo Teste de Tukey em nível de $5 \%$ de probabilidade. 
As notas baixas observadas para sabor amargo mostram que este fenômeno não ocorre nem para as maçãs MP controle e nem é conferido pela solução conservadora ou películas adicionadas.

Os parâmetros analisados de sabor (característico de maçã, doce, ácido e amargo) praticamente não apresentaram diferença significativa entre os tratamentos. O sabor fresco foi notado pelos provadores no tratamento solução conservadora, fécula de mandioca e dextrina de fécula de mandioca. A solução conservadora foi o único tratamento em que detectou-se sabor salgado.

\subsubsection{Textura}

\subsubsection{Característica de maçã}

Os tratamentos solução conservadora e dextrina apresentaram maçãs MP com textura mais próxima da maçã natural nos primeiros dias de armazenamento. Dentro do $9^{\circ}$ e $13^{\circ}$ dias de armazenamento, entretanto, não houve mais diferença significativa entre os tratamentos (Tabela 25).

Em relação ao tempo de armazenamento, no tratamento controle, os provadores perceberam perda significativa na textura característica das maçãs MP no $5^{\circ}$ dia, nos demais tratamentos esta percepção foi apenas no $9^{\circ}$ dia de armazenamento.

Tabela 25. Médias das notas dos provadores para textura da maçã MP em função dos tratamentos e do tempo de armazenamento

\begin{tabular}{lcccc}
\hline & \multicolumn{4}{c}{ Tempo de armazenamento (dias) } \\
\hline Tratamentos & 1 & 5 & 9 & 13 \\
\hline Controle & $7,0 \mathrm{aA}$ & $4,0 \mathrm{bB}$ & $2,5 \mathrm{aB}$ & $1,7 \mathrm{aB}$ \\
Solução conservadora & $7,1 \mathrm{aA}$ & $6,1 \mathrm{aA}$ & $3,8 \mathrm{aB}$ & $3,8 \mathrm{aB}$ \\
Fécula de mandioca & $5,8 \mathrm{bA}$ & $4,2 \mathrm{bA}$ & $3,8 \mathrm{aAB}$ & $3,2 \mathrm{aB}$ \\
Dextrina de mandioca & $7,0 \mathrm{aA}$ & $6,0 \mathrm{aA}$ & $4,1 \mathrm{aB}$ & $3,6 \mathrm{aB}$ \\
Alginato de sódio & $5,0 \mathrm{bA}$ & $4,0 \mathrm{bA}$ & $3,6 \mathrm{aAB}$ & $3,2 \mathrm{aB}$ \\
\hline Médias seguidas de mesma letra minúscula na coluna e maiúscula na linha não diferem entre \\
si, pelo Teste de Tukey em nível de 5\% de probabilidade.
\end{tabular}




\subsubsection{Maciez}

Os tratamentos não apresentaram diferenças significativas entre si até o $5^{\circ}$ dia de armazenamento quanto à maciez das maçãs MP (Tabela 26. Posteriormente, o tratamento da solução conservadora diferenciou-se apresentando produto com textura mais consistente no $9^{\circ}$ dia de armazenamento e no $13^{\circ}$ dia não diferiu estatisticamente do tratamento com dextrina. Esta firmeza pode ter sido promovida pela presença de cálcio na solução conservadora.

Em relação aos dias de armazenamento, os tratamentos controle, fécula de mandioca e alginato não apresentaram alteração significativa de maciez no tempo. A mudança da maciez das maçãs foi detectada pelos provadores no $13^{\circ}$ dia de armazenamento para os demais tratamentos.

Tabela 26. Médias das notas dos provadores para maciez das maçãs MP em função dos tratamentos e do tempo de armazenamento

\begin{tabular}{lcccc}
\hline & \multicolumn{4}{c}{ Tempo de armazenamento (dias) } \\
\hline Tratamentos & 1 & 5 & 9 & 13 \\
\hline Controle & $7,0 \mathrm{aA}$ & $7,0 \mathrm{aA}$ & $7,6 \mathrm{aA}$ & $7,7 \mathrm{aA}$ \\
Solução conservadora & $6,0 \mathrm{aA}$ & $6,8 \mathrm{aA}$ & $4,5 \mathrm{bAB}$ & $3,3 \mathrm{bB}$ \\
Fécula de mandioca & $7,0 \mathrm{aA}$ & $6,8 \mathrm{aA}$ & $6,2 \mathrm{aA}$ & $6,0 \mathrm{aA}$ \\
Dextrina de mandioca & $7,0 \mathrm{aA}$ & $7,0 \mathrm{aA}$ & $6,1 \mathrm{aA}$ & $3,6 \mathrm{bB}$ \\
Alginato de sódio & $7,0 \mathrm{aA}$ & $7,1 \mathrm{aA}$ & $7,2 \mathrm{aA}$ & $7,0 \mathrm{aA}$ \\
\hline Médias seguidas de mesma letra minúscula na coluna e maiúscula na linha não diferem entre \\
si, pelo Teste de Tukey em nível de 5\% de probabilidade.
\end{tabular}

\subsubsection{Umidade}

O tratamento com alginato apresentou maiores valores, isto é, maçãs MP mais suculentas e crocantes que os demais tratamentos. No entanto, a partir do $5^{\circ}$ dia de armazenamento, o tratamento apresentou diferença significativa somente em relação ao tratamento controle (Tabela 27). A partir do $9^{\circ}$ dia apresentou-se diferente do tratamento com dextrina também e no $13^{\circ}$ dia diferenciou-se da solução conservadora. A elevada umidade das maçãs MP 
tratadas com alginato pode ser justificada pela espessura da película, como foi verificado na análise físico-química, maior teor de umidade às amostras.

Em relação ao tempo de armazenamento, as maçãs MP do tratamento solução conservadora e fécula de mandioca não apresentaram diferença significativa para umidade dentro de textura. No entanto, a mudança de textura foi detectada no $5^{\circ}$ dia pelos provadores para os tratamentos controle e alginato; e no tratamento dextrina esta mudança ocorreu apenas no $9^{\circ} \mathrm{dia}$.

Tabela 27. Médias das notas dos provadores para umidade das maçãs MP em função dos tratamentos e do tempo de armazenamento

Tempo de armazenamento (dias)

\begin{tabular}{lcccc}
\hline Tratamentos & 1 & 5 & 9 & 13 \\
\hline Controle & $6,2 \mathrm{bA}$ & $3,7 \mathrm{bB}$ & $1,6 \mathrm{bB}$ & $2,1 \mathrm{cB}$ \\
Solução conservadora & $5,8 \mathrm{bA}$ & $5,0 \mathrm{aA}$ & $5,0 \mathrm{aA}$ & $4,6 \mathrm{bA}$ \\
Fécula de mandioca & $5,0 \mathrm{bA}$ & $4,5 \mathrm{abA}$ & $5,1 \mathrm{aA}$ & $6,6 \mathrm{aA}$ \\
Dextrina de mandioca & $6,3 \mathrm{bA}$ & $4,7 \mathrm{aA}$ & $2,8 \mathrm{bB}$ & $2,7 \mathrm{cB}$ \\
Alginato de sódio & $9,0 \mathrm{aA}$ & $6,5 \mathrm{aB}$ & $6,7 \mathrm{aB}$ & $6,7 \mathrm{aB}$ \\
\hline
\end{tabular}

Médias seguidas de mesma letra minúscula na coluna e maiúscula na linha não diferem entre si, pelo Teste de Tukey em nível de 5\% de probabilidade.

Nos parâmetros de textura (característica de maçã e maciez) a solução conservadora apresentou maçãs MP com as melhores notas. A textura mais suculenta foi atribuída às maçãs MP tratadas com alginato.

Comparando os diversos parâmetros apontados pelos provadores pode ser verificado que o tratamento com solução conservadora destacou-se como sendo um tratamento promissor na análise sensorial pelas notas satisfatórias obtidas. Nos atributos em que o tratamento alginato obteve boas notas, aparência úmida e textura úmida, pode ter sido uma dedução induzida dos provadores pela maior espessura da película e não pela umidade da maçã em si. 


\section{CONSIDERAÇÕES FINAIS}

- Comparativamente ao tratamento controle, as maçãs MP tratadas com solução conservadora apresentaram processo respiratório e produção de etileno minimizados. A solução promoveu maior claridade das polpas em função dos agentes branqueadores e antioxidantes utilizados e também em função da maior acidez que promoveram. A firmeza dessas maçãs aumentou com o tempo de armazenamento.

- O uso de películas resultou em redução média de 38\% na taxa respiratória e mais de 50\% na produção de etileno das maçãs MP em relação ao tratamento controle. A película de alginato de sódio destacou-se como o mais eficiente na desaceleração dos processos fisiológicos das frutas MP, o que é indicativo de melhor controle da senescência.

- A película de alginato de sódio vista em microscópio eletrônico de varredura, destacou-se das demais (dextrina e fécula) pela homogeneidade e ausência de poros, fato que contribuiu para sua eficiência no controle da taxa respiratória e da produção de etileno.

- As maçãs MP recobertas com alginato apresentaram a melhor retenção de umidade no início do armazenamento. Entretanto, houve perda significativa de umidade pelas maçãs MP durante o armazenamento. Esta perda foi constatada no $9^{\circ}$ dia após o processamento, quando o teor de umidade dessas maçãs se igualou aos dos demais tratamentos. 
- As maiores concentrações de sólidos solúveis totais foram verificadas nas maçãs do tratamento controle, tratada com solução conservadora e da revestida com alginato.

- Maçãs MP com alginato apresentaram menor acidez, proporcionada pelo pH elevado da solução filmogênica, além de coloração mais escura de polpa, que pode ter decorrido da coloração da própria solução de revestimento.

- No tratamento controle foi verificada redução dos valores de firmeza com o armazenamento, tendência natural do tecido vegetal no tempo. Nos demais tratamentos, que receberam adição de cálcio, a tendência foi oposta ao controle.

- As coberturas de dextrina e de fécula de mandioca exerceram, de modo geral, influência semelhante sobre as características físicas e físicoquímicas avaliadas, apresentando valores intermediários entre o tratamento com solução conservadora e o com alginato.

- $\quad$ Na maçã inteira (antes do processamento) foi detectada ausência de Salmonella. Quer nas maçãs MP tratadas com película ou sem película, não foram detectados coliformes totais e fecais durante todo o armazenamento.

- No tratamento que utilizou apenas solução conservadora as maçãs MP apresentaram notas mais próximas do natural (maçãs recémcortadas) pela análise sensorial descritiva quantitativa, tendo com isso uma melhor aceitação em relação aos parâmetros de aparência, aroma, sabor e textura. 
- $\quad$ Os tratamentos com película apresentaram boa aceitação pelos provadores nos parâmetros avaliados, exceto as maçãs MP com alginato que proporcionaram certa estranheza devido ao brilho da película. O produto foi classificado como de aparência artificial e seu sabor como sendo de "fruta passada". 


\section{CONCLUSÃO}

O tratamento com solução conservadora mostrou-se eficiente na conservação das maçãs MP. A solução possui propriedade de clarear e enrijecer a polpa, sem contundo se distanciar das características naturais das maçãs. Este fato foi constatado pelos provadores que classificaram este produto como sendo o mais próximo do natural (maçã recém-cortada).

O uso de películas comestíveis a base de dextrina, fécula de mandioca e alginato de sódio reduziu a fisiologia do vegetal, entretanto, nem sempre mostrou resultados satisfatórios na conservação de características físicas e físico-químicas de maçãs MP.

A película de alginato de sódio foi a que conservou melhor as características físicas e físico-químicas das maçãs, entretanto, a coloração e a acidez da solução filmogênica interferiram nos atributos de qualidade do produto final. Os provadores, entretanto, classificaram as frutas com esta película como de aparência artificial devido ao brilho e também com sabor de fruta velha.

Com relação ao tempo de armazenamento as alterações mais significativas nas características das maçãs MP apareceram no $9^{\circ}$ dia após processamento. 
ANEXO 
Anexo A. Certificado do Comitê de Ética

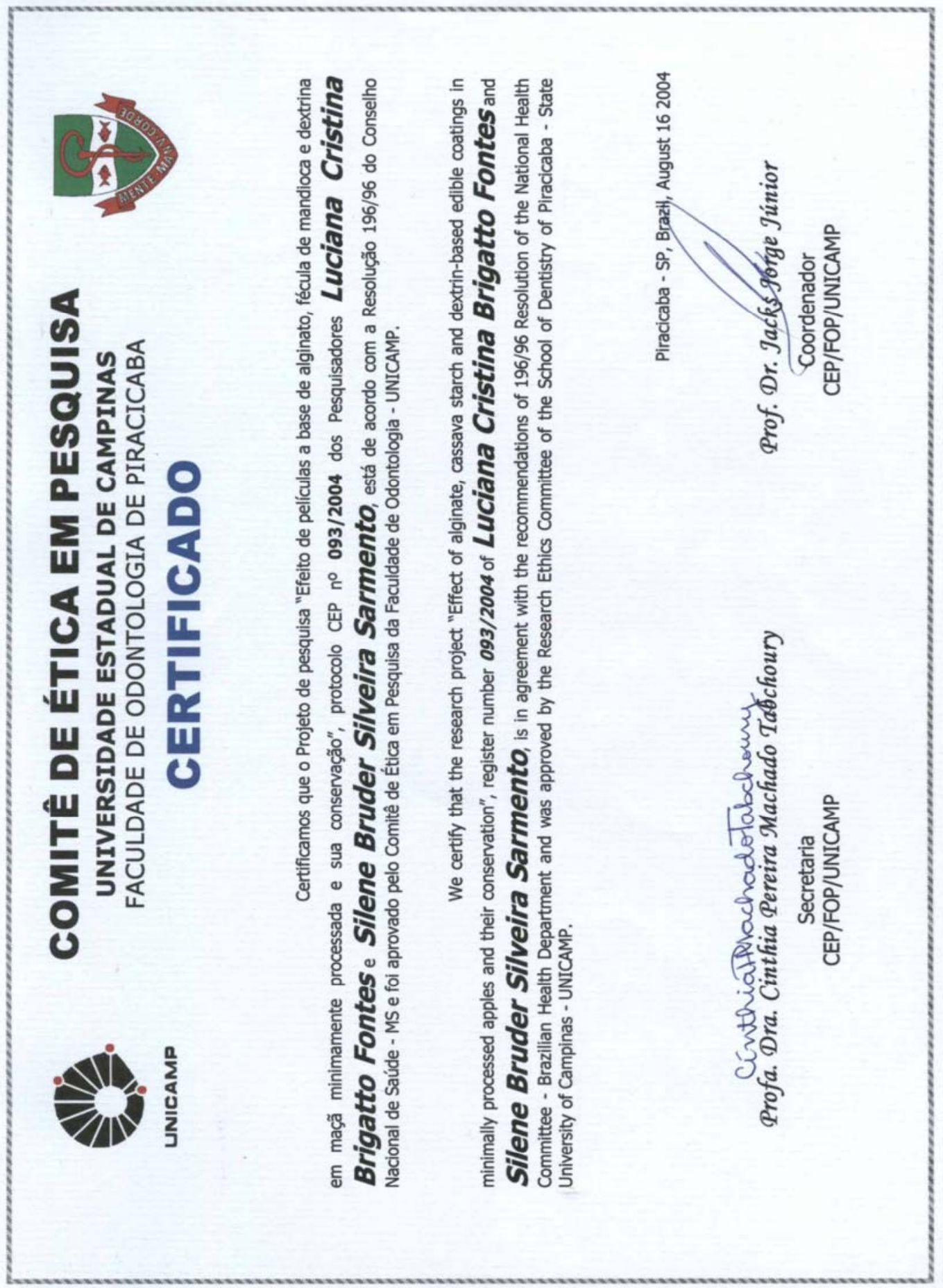




\section{REFERÊNCIAS BIBLIOGRÁFICAS}

ABE, K.; WATADA, E.A. Ethylene absorbent to maintain quality of lightly processed fruits and vegetables. Journal of Food Science, v.56, p.14931496, 1991.

AHVENAINEN, R. New approaches in improving the shelf-life of minimally processed fruit and vegetables. Trends in Food Science \& Technology, v.7, n.6, p.179-187, 1996.

ALEXANDER, R.J. Maltodextrins: production, properties and applications. In: SCHENK, F.W.; HEBEDA, R.E. Starch hydrolysis products. New York: VCH Publishers, 1992. p.233-275.

ALLONG, R.; WICKHAN, L.D.; MOHAMMED, M. Effect of slicing on the rate of respiration, ethylene production and ripening of mango fruit. Journal of Food Quality, v.24, p.405-419, 2001.

ALVARENGA, L.R.; FORTES, J.M. Cultivares de fruteiras de clima temperado. Informe Agropecuário, v.11, n.124, p.3-11, 1985.

ARGENTA, L.C.; BENDER, R.J.; KREUZ, C.L.; MONDARDO, M. Padrões de maturação e índices de colheita de maçãs cvs. Gala, Golden Delicius e Fuji. Pesquisa Agropecuária Brasileira, v.30, n.10, p.1258-1266, 1995. 
ARRUDA, M.C. Processamento mínimo de melão rendilhado: tipo de corte, temperatura de armazenamento e atmosfera modificada. Piracicaba, 2002. 71p. Dissertação (Mestrado) - Escola Superior de Agricultura Luiz de Queiroz, Universidade de São Paulo.

ASSOCIAÇÃO BRASILEIRA DE NORMAS TÉCNICAS. Teste triangular em análise sensorial dos alimentos e bebidas - NBR 12995. São Paulo, 1993.

ASSOCIATION OF OFFICIAL ANALYTICAL CHEMISTS. Official methods of analysis. 14 ed. Washington, 1992. 1141p.

AWAD, M. Fisiologia pós-colheita de frutos. São Paulo: Nobel, 1993. 114p.

BALDWIN, E. A.; NISPEROS-CARRIEDO, M. O.; SHAW, P.E.; BURNS, J.K. Effect of coatings and prolonged storage conditions on fresh orange flavor volatiles, degree Brix, and ascorbic acid levels. Journal Agriculture Food Chemistry, v.43, n.5, p.1321-1331, 1995.

BALDWIN, E. A.; NISPEROS-CARRIEDO, M. O.; BAKER, R. A. Use of edible coatings to preserve quality of lightly (and slightly) processed products. Critical Reviews in Food Science and Nutrition, v. 35, n. 6, p. 509-524, 1995a.

BALDWIN, E. A.; NISPEROS-CARRIEDO, M. O.; BAKER, R. A. Edible coatings for lightly processed fruits and vegetables. Horticulture Science, v. 30, n. 1, p. 35-38, 1995b. 
BALDWIN, E. A.; NISPEROS, M. O.; CHEN, X.; HAGENMAIER, R. D. Improving storage life of cut apple and potato with edible coating. Postharvest Biology and Technology, v. 9, n. 2, p. 151-163, 1996.

BARRIGA, M.I.; TRACHY, G.; WILLEMONT, C. et al. Microbial changes in shredded iceberg lettuce store under controlled atmosphere. Journal of Food Science, v.56, p.1586, 1991.

BARTRAM, D. Interpretation of weekly harves tests for determining long term CA storage harvest timing. Wenatchee, v. 34, n.2. p.45-54, 1993.

BASTRASH, S.; MAKHLOUF, J.; CASTAIGNE, F. Optimal controlled atmosphere conditions for storage of broccoli florets. Journal of Food Science, v.58, n.2, p.338-341, 1993.

BENNETT, A.R.; MACPHEE, S.; BETTS, R.; POST, D. Use of pyrrolidonyl peptidase to distinguish Citrobacter from Salmonella. Letters in Applied Microbiology, v.28, p.175-178, 1999.

BIBLE, B.B.; SINGHA, S. Canopy position infleneces CIELAB coordinates of peache color. HortScience, v.28, n.10, p.992-993, 1993.

BLANKE, M.M. Respiration of apple and avocad fruits. Postharvest News and Information, v.2, n.6, p.429-436, 1991.

BOBBIO, P.A. Química do processamento de alimentos. Campinas, Fundação Cargill, 1984. 
BRACKMANN, A. Einflu $\beta$ von unter Kontrollierter Atmosphare (CA) und Athylenbehandlunggen auf verschiedene Merkmale der Fruchtreife unter besonderer Berücksichtigung der Aromabildung bei Äpfeln. Hohenheim, 1990. 115p. Tesis (PhD), Universidade de Hohenheim.

BRACKMANN, A.; CHITARRA, A.B. Atmosfera controlada e atmosfera modificada. In: BOREM, F.M. (coord.). Armazenamento e processamento de produtos agrícolas. Lavras: UFLA/SBEA, 1998. p.133-169.

BRANDY, C.J. Fruits ripening. Annual Reviews of Plant Physiology, v.38, p.155-179, 1987.

BRASIL. Ministério da Saúde. Agência Nacional de Vigilância Sanitária (ANVISA). Resolução - RDC $\mathbf{n}^{\circ} \mathbf{1 2}$, de 2 de janeiro de 2001: regulamento técnico sobre padrões microbiológicos em alimentos. http://www.anvisa.gov.br/legis/resol/12_01rdc.htm (14 jun. 2002).

BRASTRASH, S.; MAKHLOUF, J.; CASTAIGNE, F. Optimal controlled atmosphere conditions for storage of broccoli florets. Journal of Food Science, v.58, n.2, p.338-341, 1993.

BRAVERMAN, J.B.S. Introducción a la bioquimica de los alimentos. Barcelona: Omega, 1967. 355p. Cap.14: Vitaminas.

BRECHT, J.K. Phisiology of lightly processed fruits and vegetables. HortScience, v.30, n.1, p.18-22, 1995. 
CALCI, K.R.; BURKHARDT III, W.; WATKINS, W.D. Occurrence of male especific bacteriophage in fecal and domestic animal wastes, human feces and human associated wastewaters. Applied and Environmental Microbiology, v.64, n.12, p.5027-5029, 1998.

CANTWELL, M. Preparation and quality of fresh produce. In: ENCONTRO NACIONAL SOBRE PROCESSAMENTO MÍNIMO DE FRUTAS E HORTALIÇAS, 2, Palestras. Viçosa: UFV, 2000. p.150-173.

CARVALHO, V.D. Qualidade e conservação de goiabas. Informe Agropecuário, v.17, n.179, p.48-54, 1994.

CEREDA, M.P., BERTOLINI, A.C., EVANGELISTA, R.M. Uso do amido em substituição às ceras na elaboração de "filmes" na conservação pós-colheita de frutas e hortaliças: estabelecimento de curvas de secagem. In: CONGRESSO BRASILEIRO DE MANDIOCA, 7; Recife, 1992. 107p.

CEREDA, M.P., BERTOLINI, A.C.,SILVA, A.P. de, OliVEIRA, M.A. de, EVANGELISTA, R.M. Películas de almidón para la preservación de frutas. In: POLÍMEROS BIODEGRADABLES, AVANCES Y PERSPECTIVAS. Anais. Buenos Aires, 1995.

CEREDA, M.P.; HENRIQUE, C.M. OlIVEIRA, M.A., FERRAZ, M.V., VICENTINI, N.M. Characterization of edible films of cassava starch by electron microscopy. Brazilian Journal of Food Tecnology, v.3, p.91-95, 2000.

CEREDA, M.P.; VILPOUX, O. Processamento de amiláceas latino americanas. São Paulo: Fundação Cargil, 2003. v.4. 
CHITARRA, M.I.F; CHITARRA, A.D. Pós-colheita de frutas e hortaliças: fisiologia e manuseio. Lavras: FAEPE, 1990. 293p.

CHITARRA, M.I.F. Processamento mínimo de frutos e hortaliças. Viçosa: Centro de Produções Técnicas, 1998. 88p.

CHITARRA, M.I.F. Processamento mínimo de frutas e hortaliças. Lavras: UFLA/FAEPE, 2000. 113p.

CHITARRA, A.B. Tecnologia de armazenamento pós-colheita para frutos e hortaliças in natura. Lavras: UFLA/FAEPE, 2002. 112p.

CONWAY, W.S.; SAMS, C.E. Possible mechanisms by which postharvest calcium treatment reduces decay in apples. Phytopatology, v.74, n.2, p.208-210, 1984.

CONWAY, W.S.; SAMS, C.E.; WATADA, A.E. Realationship between total and cell wall bound calcium in apples following postharvest presume infiltration of calcium chloride. Acta Horticulturae, n.398, p.31-39, 1995.

CRYSTAL GUM. Boletim Técnico da National Starch and Chemical Company. Divisão de Produtos Alimentícios, 2002. p.1-2.

CUQ, B.; GONTARD, N.; GUILBERT, S. Edible filmes and coatings as active layers. In: ROONEY, M.L. (Ed). Active Food Packagings. Glasgow: Blackie Academic \& Professional, 1995a. p.111-143. 
DONHOWE, I.G., FENNEMA, O. Edible films and coatings: characteristics, formation, definitions, and testing methods. In: KROCHTA, J.M.; BALDWIN, E.A.; NISPEROS-CARRIEDO, M.O. (Ed). Edible coatings and films to improve food quality. Lancaster: Technomic Publishing, 1994. p.1-24.

DUTCOSKY, S.D. Análise sensorial de alimentos. Curitiba: Editora Universitária Champagnat, 1996. 123p.

DZIEZAK, J.D. A focus on gums. Food Technology, v.45, p. 115- 132, 1991.

EMPRESA DE PESQUISA AGROPECUÁRIA E EXTENSÃO RURAL DE SANTA CATARINA (EPAGRI). A cultura da macieira. Florianópolis, 2002. $743 p$.

FAN, X. Maturity and storage of "Fuji" apples. Washington, 1992. 201p. Thesis (M.S.), Washington State University.

FANTUZZI, E. Atividade microbiana em repolho (Brassica oleraceae cv. Capitata) minimamente processado. Viçosa, 1999. 50p. Dissertação (M.S.), Universidade Federal de Viçosa.

FERREIRA, V.L.P; ALMEIDA, T.C.A.; PETTINELLI, M.L.C.; SILVA, M.A.A.P.; CHAVES, J.B.P.; BARBOSA, E.M.M. Análise sensorial: testes discriminativos e afetivos. Campinas: SBCTA, 2000. 127p. (Série Qualidade).

FMC BIOPOLYMER. Protanal - RF 6650 alginate. Product Specification Bulletin. FMC Corporation, 2000. 2 p. 
FNP Consultoria \& Comércio. Agrianual 2000: Anuário da Agricultura Brasileira. São Paulo, 2000. p.34-45: Horticultura.

FNP Consultoria \& Comércio. Agrianual 2004: Anuário da Agricultura Brasileira. São Paulo, 2004. p.24-35: Horticultura.

FONTES, L.C.B; SARMENTO, S.B.S.; SPOTTO, M.H.F. Obtenção de películas comestíveis para maçãs minimamente processadas. In: SIMPÓSIO LATINO AMERICANO DE CIÊNCIA DE ALIMENTOS. 5. Campinas-SP, 2003.

GALLO, J-A Q.; DEBEAUFORT, F.; CALLEGARIN, F.; VOILlEY, A. Lipidic hydrophobic, physical state and distribution effects on the properties of emulsion-based films. Journal Membrane Science, v.180, p.37-46, 2000.

GIL, M.I.; GORNY, J.R.; KADER, A.A. Responses of "Fuji" apple slice to ascorbic acid treatments and low oxygen atmospheres. HortScience, v.33, n.2, p.305-309, 1998.

GONTARD, N. Films et enrobages comestibles: étude et amélioration des proprietes filmogénes du gluten. Montpellier, 1991. 174p. Thèse, Université Montpellier II.

GONTARD, N. Films comestibles et biodegradables: étude des propiétés filmogènes du gluten de blé. C.R. Académie Agriculture, v.80, n.4, p.109117, 1994.

GONTARD, N.; GUILBERT, S.; Prolongation of the shelf-life of perishable food products using biodegradable films and coatings. Lebensmittel Wissenchaft und Technology, v. 29, n. 1-2, p. 10-17, 1996. 
GUILBERT, S. Use of superficial edible layer to protect intermediate moisture foods: application to the protection of tropical fruit dehydrated by osmosis. In: SEOW, C.C., (Ed.) Food preservation by moisture control. New York: Elsevier Applied Science, 1988. p.199-219.

GUILBERT, S.; GONTARD, N.; GORRIS, L. G. M. Prolongation of the shelf-life of perishable food products using biodegradable films and coatings. Lebensmittel Wissenchaft und Technology, v. 29, n. 1-2, p. 10-17, 1996.

HENRIQUE, C.M., CEREDA, M.P. Película de fécula de mandioca na conservação pós-colheita de limão Siciliano (Citrus limon (Burn)) desverdecido. In: CONGRESSO LATINO AMERICANO DE RAÍZES TROPICAIS, 1.; CONGRESSO BRASILEIRO DE MANDIOCA, 9. Anais. Botucatu: Universidade Estadual Júlio de Mesquita Filho, 1996.

HILDEBRAND, D.F. Lipoxygenases. Plant Physiology, v.76, p.249-253, 1989.

HOBBS, B.C.; ROBERTS, D. Higiene y toxicología de los alimentos. 3.ed. Zaragoza: Acribia, 1999. 478p.

HOWARD, L. R.; DEWI, T. Sensory, microbiological and chemical quality of mini-peeled carrots as affected by edible coating treatment. Journal of Food Science, v. 60, n.1, p. 142-144, 1995.

INSTITUTO ADOLFO LUTZ. Normas analíticas do instituto Adolfo Lutz. 3.ed. São Paulo, 1986. v.1,533p.

KADER, A.A. Postharvest technology of horticultural crops. 2.ed. Oakland. University of California, 1992. 296p. 
KADER, A.A. Regulation of fruit physiology by controlled/modified atmospheres. Acta Horticulturae, n.398, p.139-146, 1995.

KAPLAN, H.J. Washing, waxing and color adding. In: WARDOWSKI, S.; NAGY,S.; GRIESNSON, W. (Ed.) Fresh citrus fruits. Westport: AVI, p. 379, 1986.

KATO-NOGUCHI, H.; WATADA, A.E. Citric acid reduces the respiration of fresh-cut carrots. HortScience, v.32, p.136, 1997.

KERR, R.W. Chemistry and industry of starch. 2.ed. New York. 1950.

KESTER, J.J; FENNEMA, O.R.. Edible films and coatings: a review. Food Technology, v.40, p. 47-59, 1986.

KING, A.H. Brow seawwed extracts (alginates). In: GLICKSMAN, M.E.D. Food hydrocolloids. Boca Raton: CRC Press, 1983. v.2, chap.6, p.115-190.

KLUGE, R.A.; NACHTIGAL, J.C.; FACHINELLO, J.C.; BILHALVA, A.B. Fisiologia e manejo pós-colheita de frutas de clima temperado. Campinas: Livraria e Editora Rural, 2002, 214p.

KRAMER, A. Fruits and vegetables. In: KRAMER, A.; TWIGG, B.A. Quality control for the food industry. Connecticut: Avi, 1973, v.2, p.157-227.

KROCHTA, J. M.; MULDER-JOHNSTON, C. de. Edible and biodegradable polymer films: challenges and opportunities. Food Technology, v. 51, n. 2, p. 61-74, 1997. 
LA BELLE, R.L. Apple quality characteristics as related to various processed products. In: AMERICAN CHEMICAL SOCIETY. Quality of selected fruits and vegetables. New York: ACS Symp., 1981. p.61-76. (Série n. 170).

LABUZA, T.P.; CONTRERAS-MEDELLIN, R. Prediction of moisture protection requirements for foods. Cereal Foods Worl, v.26, p.335, 1981.

LIDSTER, P.D.; FORSYTH, F.R.; LIGHTFOOT, H.J. low oxygen and carbon dioxide atmospheres for storage of "Mclntosh" apples. Canadian Journal of Plan Science, v.60, p.299-301, 1980.

LIMA, L.C. Armazenamento de maças cv. Royal Gala sob refrigeração e atmosfera controlada. Lavras, 1999. Dissertação (M.S.), Universidade Federal de Lavras.

LITTLE, C.R. A manual of procedures for assessing apple maturity for storage schedules. Vitoria: Horticulture Research Institute, 1992. 80p.

LYON, D.H.; FRANCOMBE, M.A.; HASDELL, T.A. Guidelines for sensory analysis in food products development and quality control. London: Chapman and Hall, 1992. 131p.

MACDOWELL, R.H. Properties of alginates. 3ed. London: Alginats Industries Limites. 1973, p.1-60: Los alginatos en la alimentacion., 1973.

MAIA, L.H.; PORTE, A.; SOUZA, V.F. Filmes comestíveis: aspectos gerais, propriedades de barreira a umidade e oxigênio. Boletim do Centro de Pesquisa e Processamento de Alimentos, v.18, n.1, p.105-128, 2000. 
MASSANTINI, R.; KADER, A. A. Conservazione e mantenimento qualitativo delle fette di kiwi. Industrie Alimentari, v.34, n.36, p.357-360, 1995.

MEDCALF, D.G. Structure and composition of cereal components as related to their potencial industrial utilization: starch. In: Pomeranz, Y. (Ed.) Industrial use of cereal. Minessota: American Association of Cereal Chemists, p.121137, 1973.

MELO, B. Pequena agroindústria ganha força. O Estado de São Paulo. Suplemento Agrícola, São Paulo, 29/08/2001. p.G10-G11.

MIRANDA, R.B. Avaliação da qualidade do mamão (Carica papaya L.) minimamente processado. Lavras, 2001. 71p. Dissertação (M.S.), Universidade Federal de Lavras.

MOREIRA, G.C.; VIEITES, R.L.; CAMPOS, A.J.; DAMATTO JR, E.R.; EVANGELISTA, R.M. Caracterização fisiológica de maçã RoyalGala minimamente processada, submetida a diferentes concentrações de ácido ascórbico (compact disc). In: CONGRESSO SOCIEDADE BRASILEIRA DE CIÊNCIA E TECNOLOGIA DE ALIMENTOS. Recife, 2004. Anais. Recife, 2004.

MORETTI, C.L. Processamento mínimo de hortaliças: alternativa viável para a redução de perdas pós-colheita e agregação de valor ao agronegócio brasileiro. Horticultura Brasileira, v.17, n.2, p.1, 1999.

MURRAY, D.G.; LUFT, L.R.; LOW, D.E. Corn starch hydrolysates. Food Technology, v.27, n.3, p.32, 1973. 
NEGUYEN-the,C.; CARLIN, F. The microbiology of minimally processed fresh fruits and vegetables. Critical Reviews in Food Science and Nutrition, v.34, n.4, p.371-401, 1994.

NICOLI, M.C.; ANESE, M.; SEVERINI, C. Combined effects in preventing enzimatic browning reactions in minimally processed fruit. Journal of Food Quality, v.17, p.221-229, 1994.

NOGUCHI, H. K.; WATADA, A. E. Citric acid reduces the respiration of fresh-cut carrots. HortScience, v.32, n.1, 1997.

NUSSINOVITCH, A.; HERSHKO, V. Gellan and alginate vegetable coatins. Carbohydrate Polymers, 30, p.185-192, 1996.

OLIVEIRA, M.A. de. Utilização de películas de féculas de mandioca como alternativa à cerca comercial na conservação pós-colheita de frutos de goiaba (Psidium guayava) variedade Kumagai. Piracicaba, 1996. 73p. Dissertação (Mestrado) - Escola Superior de Agricultura "Luiz de Queiroz", Universidade de São Paulo.

OLIVEIRA, M.A. de. Comportamento pós-colheita de pêssegos (Prunus pérsica L. Balstsch) revestidos com filmes a base de amido como alternativa à cera comercial. Botucatu, 2000. 99p. Tese (Doutorado) - Faculdade de Ciências Agronômicas, Universidade Paulista Julio de Mesquita Filho.

ONSOYEN, S. Alginates. In: IMENSON, A. Thickening and gelling agentes for food. 2ed. Lodon: Blackie Academic \& Profissional, 1997. p. 22-44. 
PERONI, K.M.C. Influência do cloreto de cálcio sobre a vida de prateleira de melão "amarelo" minimamente processado. Lavras, 2002. Dissertação (M.S.), Universidade Federal de Lavras.

PILON, L. Estabelecimento da vida útil de hortaliças minimamente processadas sob atmosfera modificada e refrigeração. Piracicaba, 2003. Dissertação (Mestrado). Escola Superior de Agricultura Luiz de Queiroz, Universidade de São Paulo.

PORTELA, S.I.; CANTWELL, M.I. Cutting blade sharpness affects appearance and other quality attributes of fresh-cut cantaloupe melon. Journal of Food Science, v.66, n.9, p.1265-1270, 2001.

POTTER, N.N. Food science. New York:The AVI Publishing Company, 1968.

PRÉSTAMO, G.; MANZANO, P. Peroxidases of selected fruits and vegetables and the possible use of ascorbic acid as na antioxidant. HortScience, v.28, n.1, p.48-50, 1993.

PURVIS, A.C. The role of adaptive enzymes in carbohydrates oxidation by stressed and senescing plant tissue. HortScience, v.32, n.7, p.1165-1168, 1997.

REIS, C.M.F. Manutenção da qualidade de banana "Prata" minimamente processada. Lavras, 2002. 92p. Dissertação (M.S.) - Universidade Federal de Lavras. 
RIBEIRO, G.A.; ALEIXO, J.A.G.; LIMA, N.B.F. Ocorrência de Escherichia coli enteropatogênicas em produtos lácteos comercializados em Pelotas, RS. Boletim da Sociedade Brasileira de Ciência e Tecnologia de Alimentos, v.25, n.2, p.62, 1991.

ROCHA, A.M.C.N.; MORAIS, A.M.M.B. Influence of controlled atmosphere storage on polyphenoloxidase activity relation to color changes of minimally processed "Jonagored" apple. International Journal of Food Science and Technology, v.36, p.425-432, 2001.

ROLLE, R.S.; CHISM, III, G.W. Physiological consequences of minimally procesed frutis and vegetables. Journal of Food Quality, v.10, n.3, p.157177, 1987.

SAKR, S. NOUBAHNI, M.; BOURBOULOUX, A. Cutting, ageing and expression of plant membrane transporters. Biochimica et Biophysica Acta, v.1330, p.207-216, 1997.

SAS/IML Software: usange and reference, version 6. Cary, 1989. 501p.

SILVA, N.; JUNQUEIRA, V.C.A.; SILVEIRA, N.F.A. Manual de métodos de análise microbiológica de alimentos. São Paulo: Livraria Varela, 1997. $295 p$.

SILVA, N. da; NETO, R.C.; JUNQUEIRA, V.C.A. et al. Manual de métodos de análise microbiológica da água. Campinas: ITAL, 2000. 99p.

SILVA JUNIOR, E.A. Manual de controle higiênico-sanitário em alimentos. 4ed. São Paulo: Varela, 2001. 477p. 
SPOTO, M.H.F. Radiação gama na conservação do suco concentrado de laranja: características físicas, químicas e sensoriais. Piracicaba, 1989. 91p. Dissertação (Mestrado) - Escola Superior de Agricultura Luiz de Queiroz, Universidade de São Paulo.

STONE, H.; SIDEL, J.L. Sensory evaluation practices. London: Academic Press, 1985. p.202-206.

STONE, E.J. Quantitative descriptive analysis. In: HOOTMANN, R.C. (Ed.). Manual on descriptive analysis testing). West. Conshohoken: ASTM, 1992. (Manual Series MNL, 13).

TAIZ, L.; ZEIGER, E. Plant physiology. 3.ed. Porto Alegre: Artmed, 2004. cap.22, p.541-559.

TREPTOW, R.O.; MINIONI, E.C.; ZONTA, E.P. Avaliação sensorial de maçãs cultivar Golden Delicious conservadas sob refrigeração. Boletim da Sociedade Brasileira de Ciência e Tecnologia de Alimentos , v.24, n.(1/2), p.49-63, 1990.

VANDERZANT, C.; SPLITTSTOESSER, D.F. Compedium of methods for the microbiological examination of foods. 3ed. Washington: APHA, 1992. $1219 p$.

VAROQUAUX, P.; LECENDRE, I.; VAROQUAUX, F. et al. Change in firmness of kiwi after slicing. Sciences des Aliments, v.10, n.1, p.127-139, 1990. 
VAROQUAUX, P.; WILEY, R.C. Cambios biológicos y bioquímicos en frutas y hortaliças refrigeradas minimamente processadas. In: WILEY, R.C. Frutas y hortaliças minimamente processadas y refrigeradas. Zaragoza: Acribia, 1997. p. 221-262.

VICENTINI, N.M.; CEREDA, M.P.; CÂMARA, F.L.A. Utilização de películas de fécula de mandioca na perda de peso e coloração de frutos de pimentão (Capsicum annuum L. Science Agriculture, v.2, n.24, p. 16-25, 1998a.

VICENTINI, N.M. Utilização de películas de fécula de mandioca para a conservação pós-colheita de couve-flor (Brassica oleraceae var. botrytis). Botucatu, 1999. Dissertação (Mestrado) - Faculdade de Agronomia, Universidade Estadual Paulista Julio de Mesquita Filho.

VIEIRA, A.P. VIEITES, R.L., EVANGELISTA, R.M. Película de fécula de mandioca no abacaxi minimamente processado. In: CONGRESSO BRASILEIRO DE CIÊNCIA E TECNOLOGIA DE ALIMENTOS, 17. Fortaleza, 2000. Anais. Fortaleza: SBCTA, 2000. p.3.61.

VITTI, M.C.D. Aspectos fisiológicos, bioquímicos e microbiológicos em beterrabas minimamente processadas. Piracicaba, 2003. Dissertação (Mestrado). Escola Superior de Agricultura Luiz de Queiroz, Universidade de São Paulo.

WATADA, A.E.; ABE, K.; YAMUCHI, N. Physiological activities of partially processed fruits and vegetables. Food Technology, v.44, p.116-122, 1990.

WATADA, A.E.; QI,L. Quality of fresh-cut produce. Postharvest Biology and Technology, v.15, n. 3, p. 201-205, 1999. 
WHISTLER, R.L.; BEMILLER, J.N.; PASCHALL, E.F. Starch chemistry and tecnology. San Diego: Academic Press, 1984. 718p.

WHISTLER, R.L.; BEMILLER, J.N. Carbohydrate chemistry for food scientists. San Diego: Academic Press, 1997. 214p.

WILEY, R.C. Minimally processed refrigerated fruits \& vegetables. NewYork: Chapman \& Hall, 1994. 368p.

WILLS, R.H.; LEE, T.H.; GRAHAM, D. et al. Postharvest: an introduction to the physiology and handling of fruit and vegetables. London: Granada, 1981. $162 p$.

WONG, D. W. S.; TILLIN, S. J.; HUDSON, J. S.; PAVLATH, A. E. Gas exchange in cut apples with bilayer coatings. Journal of Agriculture and Food Chemistry, v.42, n.10, p. 2278-2285, 1994.

YANG, S.F. The role of ethylene and ethylene synthesis in fruit ripening. In: THOMSON, W.W.; NOTHNAGEL, E.A.; HUFFAKER, R.C. (Ed.) Plant senescence: its biochemistry and physiology. Rockville: American Society of Plant Physiologist. 1987. p.156-166. 